Title: Second Annual Topical Report: Sensitivity of Fischer-Tropsch synthesis and water-gas shift catalysts to poisons from high-temperature high-pressure entrained-flow (EF) oxygenblown gasifier gasification of coal/biomass mixtures

Type of Report: Topical

Reporting Period Start Date: October 1, 2009

Reporting Period End Date: September 30, 2010

Principal Author(s): Burtron H. Davis (PI), Gary Jacobs (co-PI), Wenping Ma (researcher),

Khalid Azzam (researcher), Dennis E. Sparks (researcher), and Wilson Shafer (researcher)

Date Report was Issued: October 25, 2010

DOE Award Number: DE-FC26-08NT0006368

Name and Address of Submitting Organization: University of Kentucky Research Foundation (UKRF) 


\section{DISCLAIMER* --}

This report was prepared as an account of work sponsored by an agency of the United States Government. Neither the United States Government nor any agency thereof, nor any of their employees, makes any warranty, express or implied, or assumes any legal liability or responsibility for the accuracy, completeness, or usefulness of any information, apparatus, product, or process disclosed, or represents that its use would not infringe privately owned rights. Reference herein to any specific commercial product, process, or service by trade name, trademark, manufacturer, or otherwise does not necessarily constitute or imply its endorsement, recommendation, or favoring by the United States Government or any agency thereof. The views and opinions of authors expressed herein do not necessarily state or reflect those of the United States Government or any agency thereof. 


\begin{abstract}
The successful adaptation of conventional cobalt and iron-based Fischer-Tropsch synthesis catalysts for use in converting biomass-derived syngas hinges in part on understanding their susceptibility to byproducts produced during the biomass gasification process. With the possibility that oil production will peak in the near future, and due to concerns in maintaining energy security, the conversion of biomass-derived syngas and syngas derived from coal/biomass blends to Fischer-Tropsch synthesis products to liquid fuels may provide a sustainable path forward, especially considering if carbon sequestration can be successfully demonstrated. However, one current drawback is that it is unknown whether conventional catalysts based on iron and cobalt will be suitable without proper development because, while ash, sulfur compounds, traces of metals, halide compounds, and nitrogen-containing chemicals will likely be lower in concentration in syngas derived from mixtures of coal and biomass (i.e., using an entrained-flow oxygen-blown gasifier) than solely from coal, other byproducts may be present in higher concentrations. The current project examines the impact of a number of potential byproducts of concern from the gasification of biomass process, including compounds containing alkali chemicals like the chlorides of sodium and potassium.

In the second year, researchers from the University of Kentucky Center for Applied Energy Research (UK-CAER) continued the project by evaluating the sensitivity of a commercial iron-chromia high temperature water-gas shift catalyst (WGS) to a number of different compounds, including $\mathrm{KHCO}_{3}, \mathrm{NaHCO}_{3}, \mathrm{HCl}, \mathrm{HBr}, \mathrm{HF}, \mathrm{H}_{2} \mathrm{~S}, \mathrm{NH}_{3}$, and a combination of $\mathrm{H}_{2} \mathrm{~S}$ and $\mathrm{NH}_{3}$. Cobalt and iron-based Fischer-Tropsch synthesis (FT) catalysts were also subjected to a number of the same compounds in order to evaluate their sensitivities.
\end{abstract}




\section{TABLE OF CONTENTS}

$\underline{\text { Page }}$

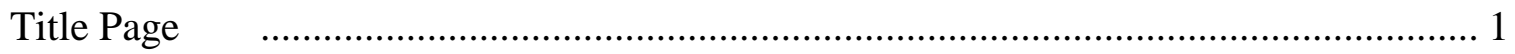

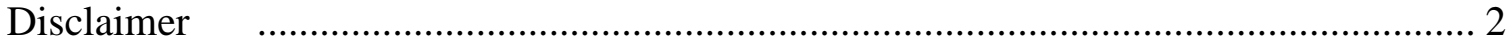

Abstract

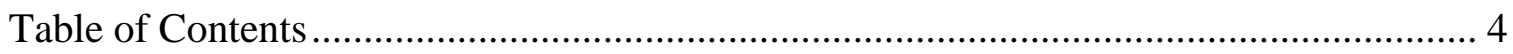

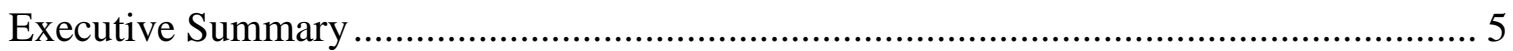

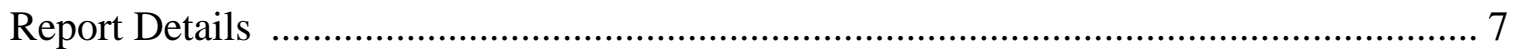

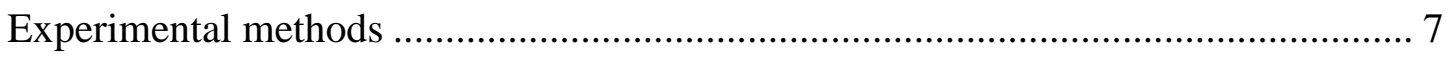

Catalyst Preparation/Procurement ......................................................... 7

Catalyst Characterization ...................................................................... 7

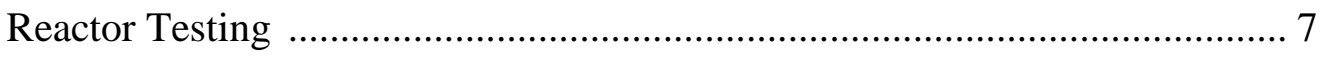

Fischer-Tropsch synthesis: Cobalt catalyst ...................................... 7

Fischer-Tropsch synthesis: Iron catalyst............................................. 9

High temperature water-gas shift: Fe-Cr catalyst ................................. 9

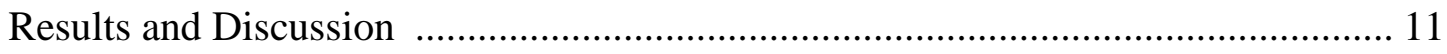

A. Water Gas Shift reaction: Sensitivity of HTS catalyst to byproducts...... 11

1. Corrigendum to Year 2009 HTS results .......................................... 11

2. Accumulation of $\mathrm{NaCl}$ and $\mathrm{KCl}$ on catalyst surface ........................ 16

3. Decoupling poisoning impact of alkali and halide ......................... 19

4. Impact of additional gasification byproducts ................................... 22

B. FT reaction: Sensitivity of Fe catalyst to co-fed gasification byproducts 26

1. Sensitivity of Fe catalyst to alkali halides....................................... 26

2. Decoupling poisoning impact of alkali and halide ........................... 29

3. Impact of additional gasification byproducts.................................. 36

C. FT reaction: Sensitivity of Co catalysts to gasification byproducts......... 45

1. Sensitivity of Co catalyst to alkali halides ........................................ 45

2. Decoupling poisoning impact of alkali and halide .......................... 51

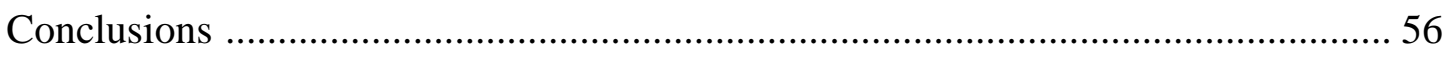

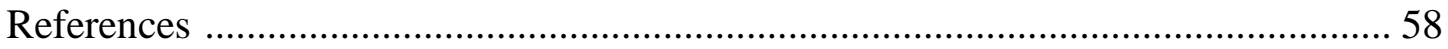




\section{Executive Summary}

Over the past year, the sensitivity of the Sud-Chemie, Inc. high temperature shift (HTS) FeCr catalyst to various compounds of interest was evaluated using a fixed bed reactor. Recall that in year \#1, the aim was to assess the impact of alkali halides (e.g., $\mathrm{KCl}, \mathrm{NaCl}$ ) on activity, while in year \#2 the primary focus was to decouple the impact of the alkali from the halide. To accomplish this, the catalyst was subjected to alkali bicarbonates and acid halides. The activity and stability of the HTS catalyst for the WGS reaction as a function of TOS under 100 ppbw $\mathrm{KHCO}_{3}$ and 100 ppbw $\mathrm{NaHCO}_{3}$ concentrations was conducted first. At the 100 ppbw level of either $\mathrm{KHCO}_{3}$ or $\mathrm{NaHCO}_{3}$, the catalyst displayed little deactivation during 21 days of TOS, at which the $\mathrm{CO}$ conversion dropped from 85 to $81 \%\left(\mathrm{KHCO}_{3}\right)$ and from 85 to $78 \%\left(\mathrm{NaHCO}_{3}\right)$, respectively. This result is somewhat surprising when compared to the case of the $100 \mathrm{ppbw}$ $\mathrm{KCl}$ poisoning study, where the catalyst was not only stable under the 100 ppbw $\mathrm{KCl}$, but $\mathrm{K}^{+}$ was also found to enhance WGS activity (see first annual report). The impact of halide ions (e.g., $\mathrm{Cl}^{-}$by addition of 100 ppbw $\mathrm{HCl}$; $\mathrm{Br}^{-}$with 100 ppbw $\mathrm{HBr}$; and $\mathrm{F}^{-}$with 100 ppbw $\mathrm{HF}$ ) on catalyst stability was also investigated, and little deactivation was observed during 21 days of TOS, where CO conversion dropped from 85 to $82 \%$ in the case of $\mathrm{HCl}$ addition, and virtually no statistically significant deactivation was observed in the case of either $\mathrm{HBr}$ or $\mathrm{HF}$ co-feeding. Following the alkali halide decoupling study, the catalyst was then subjected to additional potential contaminants. During three weeks of sulfur poisoning by the addition of $1 \mathrm{ppmv}_{2} \mathrm{~S}$ under typical HTS conditions, the Fe-Cr based catalyst showed only a slightly lower CO conversion rate - approximately $2 \%$ less than that of a reference test carried out in the absence of sulfur poisoning. The catalyst was also found to be quite resistant to $\mathrm{NH}_{3}$ poisoning up to 5 ppm, while a slight decrease in activity was observed at higher levels (e.g., 12 ppm). Combinations of $\mathrm{NH}_{3}$ and $\mathrm{H}_{2} \mathrm{~S}$ were also examined, and a slight decrease in catalytic activity was only observed at the highest levels tested (e.g., 6 ppm $\mathrm{NH}_{3}, 0.6 \mathrm{ppm} \mathrm{H}_{2} \mathrm{~S}$ ).

Turning to the Fischer-Tropsch synthesis reaction, poisoning tests were conducted using continuously stirred tank reactors (CSTR). The $100 \mathrm{Fe} / 5.1 \mathrm{Si} / 3 \mathrm{~K} / 2 \mathrm{Cu}$ catalyst was found to be quite stable at 100 ppbw levels of $\mathrm{KCl}, \mathrm{NaCl}, \mathrm{KHCO}_{3}$, and $\mathrm{NaHCO}_{3}$, and at 400 ppbw levels of $\mathrm{NaCl}$ and $\mathrm{NaHCO}_{3}$. However, increasing the $\mathrm{KCl}$ or $\mathrm{KHCO}_{3}$ level to 400 ppbw led to a more rapid decline in $\mathrm{CO}$ conversion. Furthermore, increasing $\mathrm{NaHCO}_{3}$ to $40 \mathrm{ppm}$ also resulted in severe deactivation. In all cases, $\mathrm{C}_{5}+$ and $\mathrm{C}_{1}$ selectivities were not significantly affected, although $\mathrm{CO}_{2}$ selectivity was observed to increase slightly during the course of each poisoning test. The iron catalyst was then subjected to Fischer-Tropsch (FT) feeds containing $\mathrm{HCl}$ and, separately, $\mathrm{HBr}$. When 100 ppbw or 400 ppbw of $\mathrm{HCl}$ was added, the iron catalyst was quite resistant., while in the case of $\mathrm{HBr}$ addition, the catalyst did decline in $\mathrm{CO}$ conversion during the first period of addition using 100 ppbw, but after a brief period without co-feeding of $\mathrm{HBr}, 400$ ppbw of $\mathrm{HBr}$ was added and the catalyst showed no further decline in CO conversion over more than 100 hours. At the highest levels of poisoning, $40 \mathrm{ppm}$, the catalyst displayed severe deactivation with both $\mathrm{HCl}$ and $\mathrm{HBr}$. During deactivation, $\mathrm{C}_{5}+$ selectivity declined somewhat, while that of $\mathrm{C}_{1}$ increased, but never reaching higher than $5 \%$. Likewise, $\mathrm{CO}_{2}$ selectivity was only found to significantly decrease during poisoning of either $\mathrm{HCl}$ or $\mathrm{HBr}$ at the $40 \mathrm{ppm}$ level. With the addition of $\mathrm{NH}_{4} \mathrm{NO}_{3}$ to the feed, at levels up to 10 ppmw $\mathrm{NH}_{4} \mathrm{NO}_{3}$, it appears that the catalyst was quite resistant to poisoning; however, at higher levels $40 \mathrm{ppmw}$ accelerated deactivation was noted. Additional tests will be required to verify repeatability, as unexpected interruptions (e.g., a building power outage) were encountered during the run. 
Finally, the sensitivity of a cobalt catalyst to Fischer-Tropsch synthesis under $\mathrm{KCl}$ and $\mathrm{NaCl}$ co-feeding was also assessed. Extensive testing of the poisoning effect of potassium chloride (KCl) on $0.5 \% \mathrm{Pt}-25 \% \mathrm{Co} / \gamma-\mathrm{Al}_{2} \mathrm{O}_{3}\left(150 \mathrm{~m}^{2} / \mathrm{g}\right.$ support) was carried out. Tests were carried out at 100, 190, and $600 \mathrm{ppb}$, followed by 2, 20, 100, 500 and $860 \mathrm{ppm}$. No discernible poisoning effects were observed for all but the highest concentrations. At the relatively high level of $500 \mathrm{ppm} \mathrm{KCl}$, the rate of decline was $\sim 0.7 \%$ per day, thus displaying evidence of some poisoning due to $\mathrm{KCl}$. A final test was conducted by doubling the aqueous solution feed rate to 4 $\mathrm{ml} / \mathrm{hr}$, increasing the $\mathrm{KCl}$ concentration in the syngas to $860 \mathrm{ppmw}$. In that case, the $\mathrm{CO}$ conversion decreased rapidly and did not recover when the $\mathrm{KCl}$ feed was discontinued. With $\mathrm{NaCl}$, no discernible impact was observed at the $100 \mathrm{ppb}$ and $1 \mathrm{ppm}$ poisoning levels, but a run with a high concentration of $134 \mathrm{ppm}$ led to a decrease from $\mathrm{X}_{\mathrm{CO}}=40 \%$ to $30 \%$ in just two days.

Finally, the sensitivity of a cobalt catalyst to Fischer-Tropsch synthesis under $\mathrm{KHCO}_{3} \mathrm{Co}-$ feeding was also assessed. Starting with $100 \mathrm{ppb}(\mathrm{wt})$ in the total syngas feed, the $\mathrm{KHCO}_{3}$ concentration was increased to 1 ppm, 10 ppm, 100 ppm and finally $1000 \mathrm{ppm}$. All were performed by the injection of $1 \mathrm{ml} / \mathrm{hr}$ of aqueous $\mathrm{KHCO}_{3}$ solutions of increasing concentrations, and none of them showed any discernible loss of conversion that could be attributed to the addition of $\mathrm{KHCO}_{3}$. Similar findings were obtained with $\mathrm{NaHCO}_{3}$. Except for one case where it is believe that an interruption occurred, no measurable loss in CO conversion was found up to 1000 ppmw. Testing with $\mathrm{HCl}$ and $\mathrm{HBr}$ are ongoing. With $\mathrm{HCl}$, no loss in conversion was observed over the period of time tested at the 100 ppbw $\mathrm{HCl}$ level. However, more data is required at the $10 \mathrm{ppmw}$ level in order to make a determination, as a building power failure occurred during the run. 


\section{Report Details -}

\section{Experimental methods:}

\section{A. Catalyst Preparation/Procurement}

Preparation of the $0.5 \% \mathrm{Pt}-25 \% \mathrm{Co} / \mathrm{Al}_{2} \mathrm{O}_{3}$ and $\mathrm{Fe}-\mathrm{Si}-\mathrm{K}-\mathrm{Cu}(\mathrm{Fe} / \mathrm{Si} / \mathrm{K} / \mathrm{Cu}=100: 5.1: 3.0: 2.0)$ catalysts, and procurement a Sud-Chemie, Inc. Fe-Cr high temperature shift catalyst were reported in the Year 2009 Annual Topical Report.

\section{B. Catalyst characterization}

Characterization of the catalysts, including elemental analysis by inductively coupled plasma (ICP), BET surface area and porosity by nitrogen physisorption, temperature programmed reduction (TPR), and hydrogen chemisorption with pulse reoxidation, was reported in the Year 2009 Annual Topical Report.

\section{Reactor testing}

Cobalt catalysts: The FTS experiments over cobalt catalysts were conducted in a 1 L CSTR equipped with a magnetically driven stirrer with turbine impeller, a gas-inlet line, and a vapor outlet line with a stainless steel (SS) fritted filter placed external to the reactor. A tube fitted with a SS fritted filter (2 micron opening) extends below the liquid level of the reactor for withdrawing reactor wax to maintain a nearly constant liquid level in the reactor. Separate mass flow controllers were used to control the flow of hydrogen and carbon monoxide at the desired rate. The gases were premixed in a vessel before entering to the reactor. Carbon monoxide was passed through a vessel containing lead oxide-alumina to remove traces of iron carbonyl. The 
mixed gases entered the CSTR below the stirrer operated at $750 \mathrm{rpm}$. The reactor slurry temperature was maintained constant $\left( \pm 1^{\circ} \mathrm{C}\right)$ by a temperature controller.

Prior to loading into the CSTR, the calcined cobalt catalyst ( $15 \mathrm{~g}$ of powder) was reduced ex-situ in a fixed bed reactor at $350{ }^{\circ} \mathrm{C}$ for $10 \mathrm{~h}$ in $33 \%$ hydrogen (balance helium) at a flow rate of $1 \mathrm{~L} / \mathrm{min}$. The reactor temperature was increased from room temperature to $100{ }^{\circ} \mathrm{C}$ at the rate of $2{ }^{\circ} \mathrm{C} / \mathrm{min}$ and held at $100^{\circ} \mathrm{C}$ for $1 \mathrm{~h}$, then the temperature was increased to $350{ }^{\circ} \mathrm{C}$ at a rate of $1{ }^{\circ} \mathrm{C} / \mathrm{min}$ and kept at $350{ }^{\circ} \mathrm{C}$ for $10 \mathrm{~h}$. The catalyst was then transferred pneumatically under the protection of helium to the CSTR which contained $310 \mathrm{~g}$ of melted Polywax-3000 (polyethylene fraction with an average molecular weight of 3000). To facilitate the transfer, the fixed bed reactor was connected to the CSTR using a transfer tube fitted with a ball valve. The fixed bed reactor was pressurized with argon forcing the catalyst powder out of the reactor through the valve. The reactor was weighed before and after the transfer of the catalyst to ensure that all the catalyst powder was transferred to the CSTR. The catalyst was then reduced in situ with hydrogen at a flow rate of $60 \mathrm{SL} / \mathrm{h}$ at atmospheric pressure. With the temperature controller programmed in a ramp/soak mode, the reactor temperature was ramped up to $280{ }^{\circ} \mathrm{C}$ at a rate of $2{ }^{\circ} \mathrm{C} / \mathrm{min}$ and held at $280^{\circ} \mathrm{C}$ for 24 hours.

After the activation period, the reactor temperature was decreased to $180{ }^{\circ} \mathrm{C}$, synthesis gas $\left(\mathrm{H}_{2}\right.$ : $\left.\mathrm{CO}=2: 1\right)$ was introduced to the reactor and the pressure was increased to the desired pressure. The reactor temperature was increased to the reaction temperature at a rate of $1{ }^{\circ} \mathrm{C}$ /min. The reaction products were continuously removed from the vapor space of the reactor and passed through two traps, a warm trap maintained at $100{ }^{\circ} \mathrm{C}$ and a cold trap held at $0{ }^{\circ} \mathrm{C}$. The uncondensed vapor stream was reduced to atmospheric pressure through a letdown valve. The gas flow was measured using a wet test meter and analyzed by an online GC. The accumulated 
reactor liquid products were removed every $24 \mathrm{~h}$ by passing through a $2 \mu \mathrm{m}$ sintered metal filter located below the liquid level in the CSTR. Conversions of CO was obtained by gaschromatography analysis (micro-GC equipped with thermal conductivity detectors) of the reactor exit gas mixture. The reaction products were collected in three traps maintained at different temperatures - a hot trap $\left(200^{\circ} \mathrm{C}\right)$, a warm trap $\left(100^{\circ} \mathrm{C}\right)$ and a cold trap $\left(0^{\circ} \mathrm{C}\right)$. The products were separated into different fractions (rewax, wax, oil and aqueous) for quantification. However, the oil and the wax fractions were mixed prior to GC analysis.

Iron catalyst: The $100 \mathrm{Fe} / 5.1 \mathrm{Si} / 3.0 \mathrm{~K} / 2.0 \mathrm{Cu}$ catalyst GJ457 was tested using similar reactor system. However, the catalyst was activated in-situ in $2.0 \mathrm{Nl} / \mathrm{g}$-cat $/ \mathrm{h} \mathrm{CO}$ at $270{ }^{\circ} \mathrm{C}$ and $1 \mathrm{~atm}$ for $24 \mathrm{~h}$. During testing, the syngas $\mathrm{H}_{2} / \mathrm{CO}$ ratio was approximately 0.77 [1]. The temperature was $270^{\circ} \mathrm{C}$ and the pressure was 175 psig.

\section{$\underline{\text { Fe-Cr High temperature shift (HTS) Catalyst }}$}

For the purpose of testing high temperature water gas shift (HTS) catalysts, a fixed bed reactor setup was constructed and calibrated. A dry gas mixture is used to mimic the outlet of the coal gasification processes. The gas compositions from the Texaco gasification process are used as a guideline for the input to the HTS reactor.

The fixed bed reactor (23" in length 3/8” diameter) (Figure 1) was constructed to allow a gas mixture of $\mathrm{CO}_{\mathrm{X}}, \mathrm{N}_{2}$, and $\mathrm{H}_{2}$, to be mixed with water and passed through the Fe-Cr catalyst bed. The reactor is controlled by a three stage temperature controller, to monitor the changes in temperature throughout the fixed bed more accurately. The products are passed though a cold trap, cooled to $0^{\circ} \mathrm{C}$, set up to condense the liquids (mainly water, and its solutes) out from the 


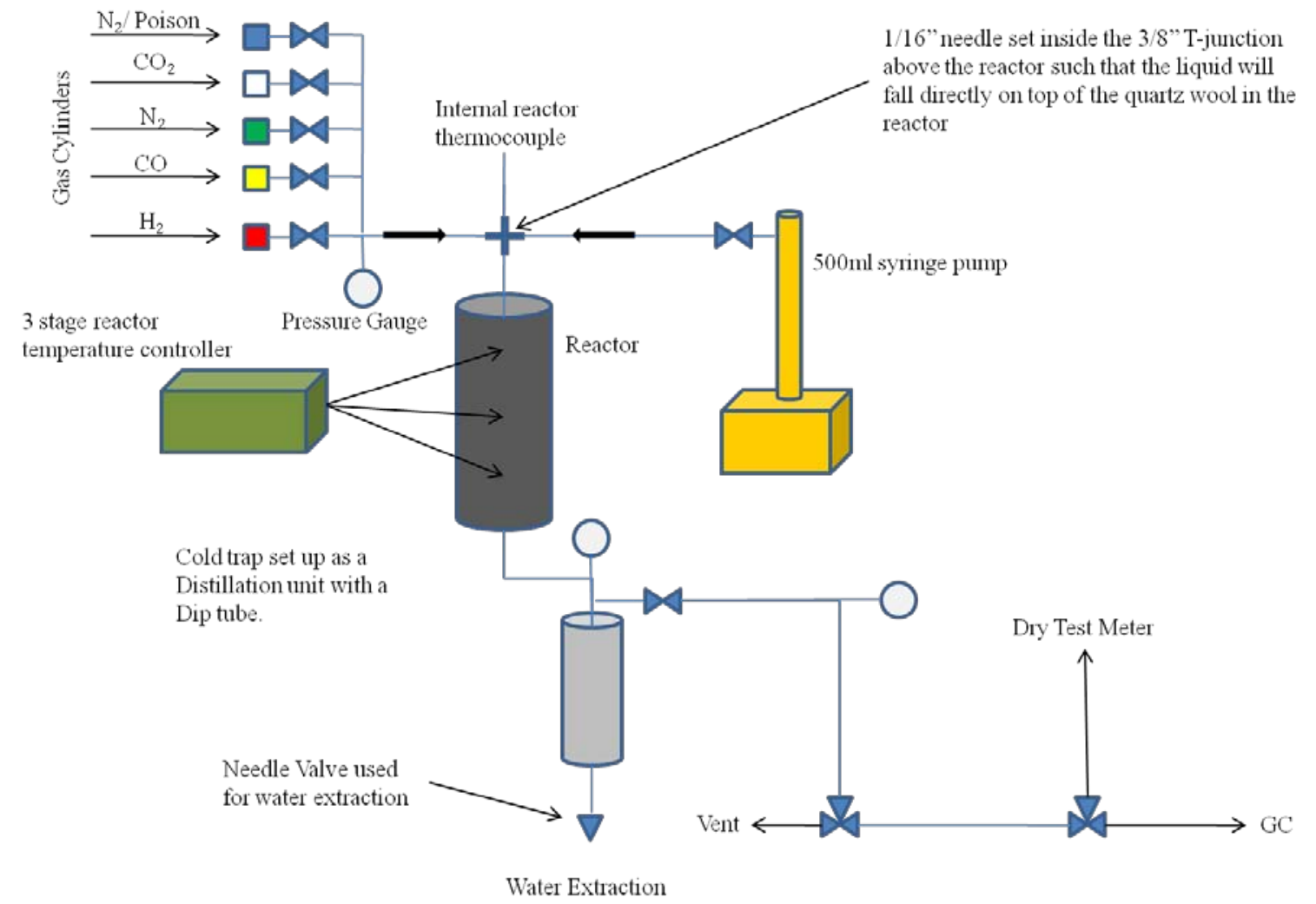

Figure 1: High-temperature shift reaction system.

gas. The liquids are extracted from the cold trap by opening a needle valve. After the gas passes thought the cold trap, an option is set up such that the gas can pass to a vent, or pass through a dry test meter for flow measurements and a GC to analyze the exiting products.

In case of liquid poisoning, the solution is pumped into the top of the reactor by a $500 \mathrm{ml}$ high performance syringe pump, and mixed with the gas before reaching the catalyst. The liquid passes though $1 / 8$ " heated stainless steel tubing, before passing into a $1 / 16$ ” needle with a side port hole. $1 / 16$ " needle is set inside the 3/8" T-junction above the reactor to allow the liquid to fall directly on top of the catalyst bed in the reactor The idea is to vaporize the water before it drips into the reactor; however, the water that is not vaporized should evenly spray and be 
distributed throughout the entire reactor. For poisoning studies, the poison is pre-mixed with the water and pumped into the reactor.

\section{Results and Discussion -}

\section{A. Water Gas Shift reaction: Sensitivity of HTS Süd-Chemie catalyst to co-fed gasification byproduct contaminants, including $\mathrm{KCl}, \mathrm{NaCl}, \mathrm{KHCO}_{3}, \mathrm{NaHCO}_{3}, \mathrm{HCl}, \mathrm{HBr}, \mathrm{HF}$, and $\mathrm{H}_{2} \mathrm{~S}$}

\section{Corrigendum to Year 2009 HTS results}

In the Year 2009 Annual Topical report, results were presented regarding the activity and stability of the Süd-Chemie Fe-Cr HTS catalyst. This included an examination of the effect of Gas Hourly Space Velocity (GHSV) on CO conversion, a stability test using a clean feed, and an assessment of the impact of $\mathrm{KCl}$ and $\mathrm{NaCl}$ poisons on catalyst performance. However, it was later found that there was a minor error in our previous calculations which biased the data slightly. Therefore, we first present the corrected results. As a result of the correction, CO conversion was found to be $5 \%$ higher than previously reported. Nevertheless, the observed trends, discussion, and conclusions reported previously are still valid. These corrected results are presented first: 


\section{Year 2009 results after correction:}

(1) WGS activity (CO conversion) versus space velocity

(2) Clean stability test for the WGS reaction over HTS - Catalyst

(3) Effect of $\mathrm{KCl}$ concentrations on the stability of HTS - WGS catalyst

(4) Effect of $\mathrm{NaCl}$ concentrations on the stability of HTS - WGS catalyst

(1) Effect of GHSV on WGS activity (CO conversion) over FeCr - HTS catalyst

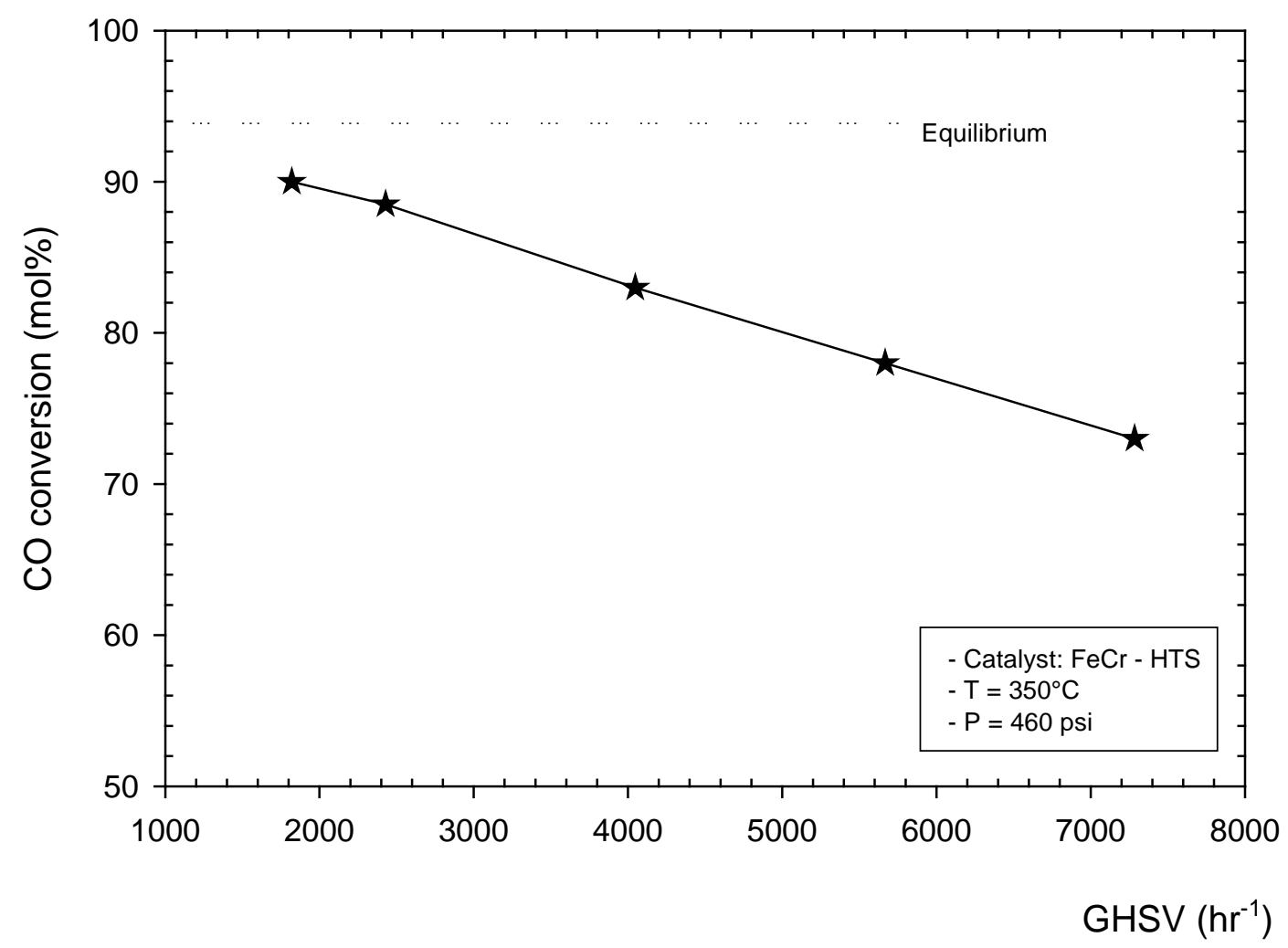

Figure 2 
(2) WGS activity (CO conversion) with time on stream over the Fe-Cr HTS commercial WGS catalyst.

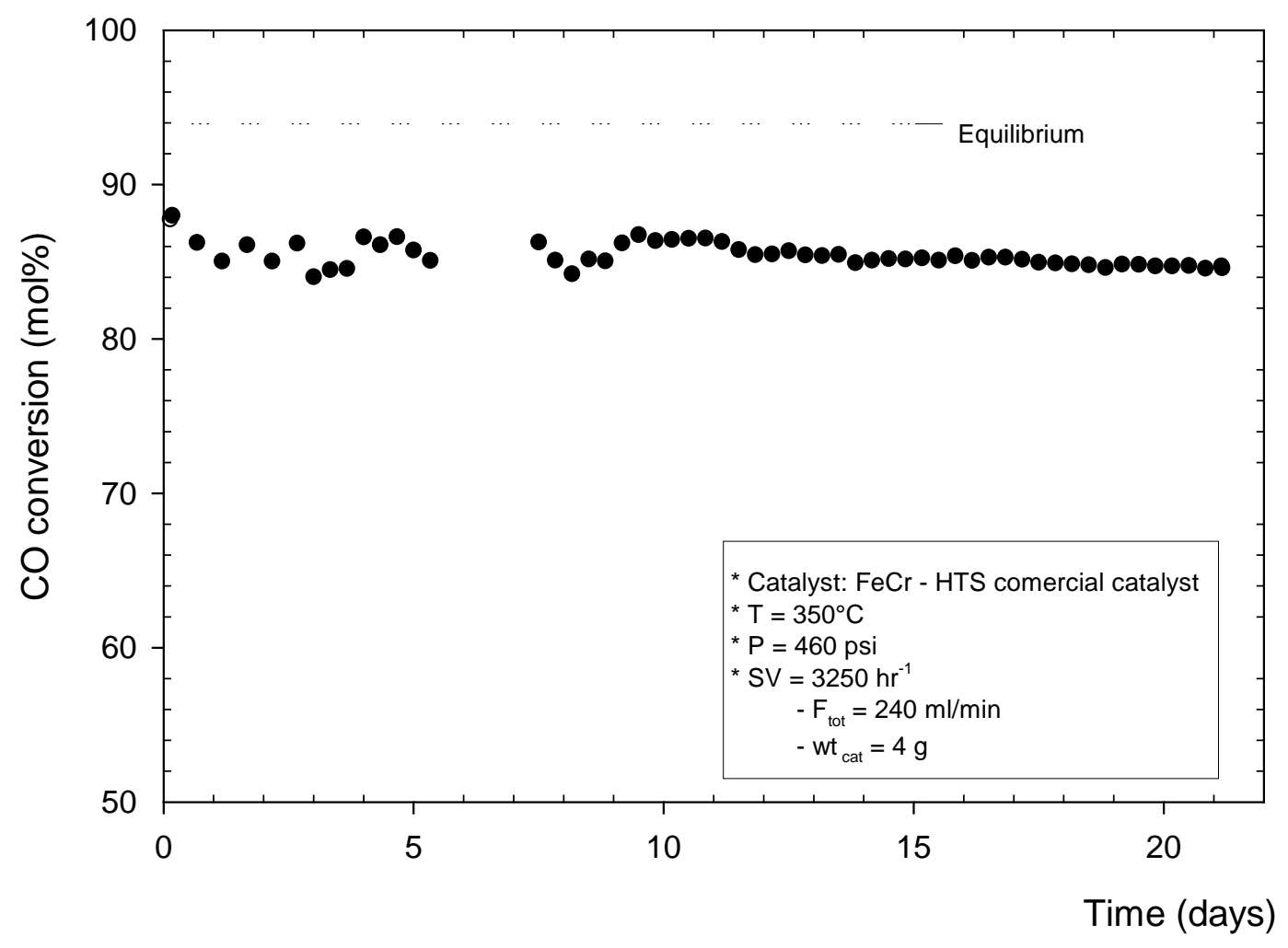

Figure 3 
(3) $\mathrm{KCl}$ concentration effect on the activity and stability of HTS - Sud-Chemie WGS catalyst in WGS reaction vs. TOS. Tests conditions are $350^{\circ} \mathrm{C}, 460 \mathrm{psi}, 3250 \mathrm{hr}^{-1}, 240$ $\mathrm{ml} / \mathrm{min}$ (steam/dry gas ratio of 1 ), catalyst weight of $4 \mathrm{~g}$.

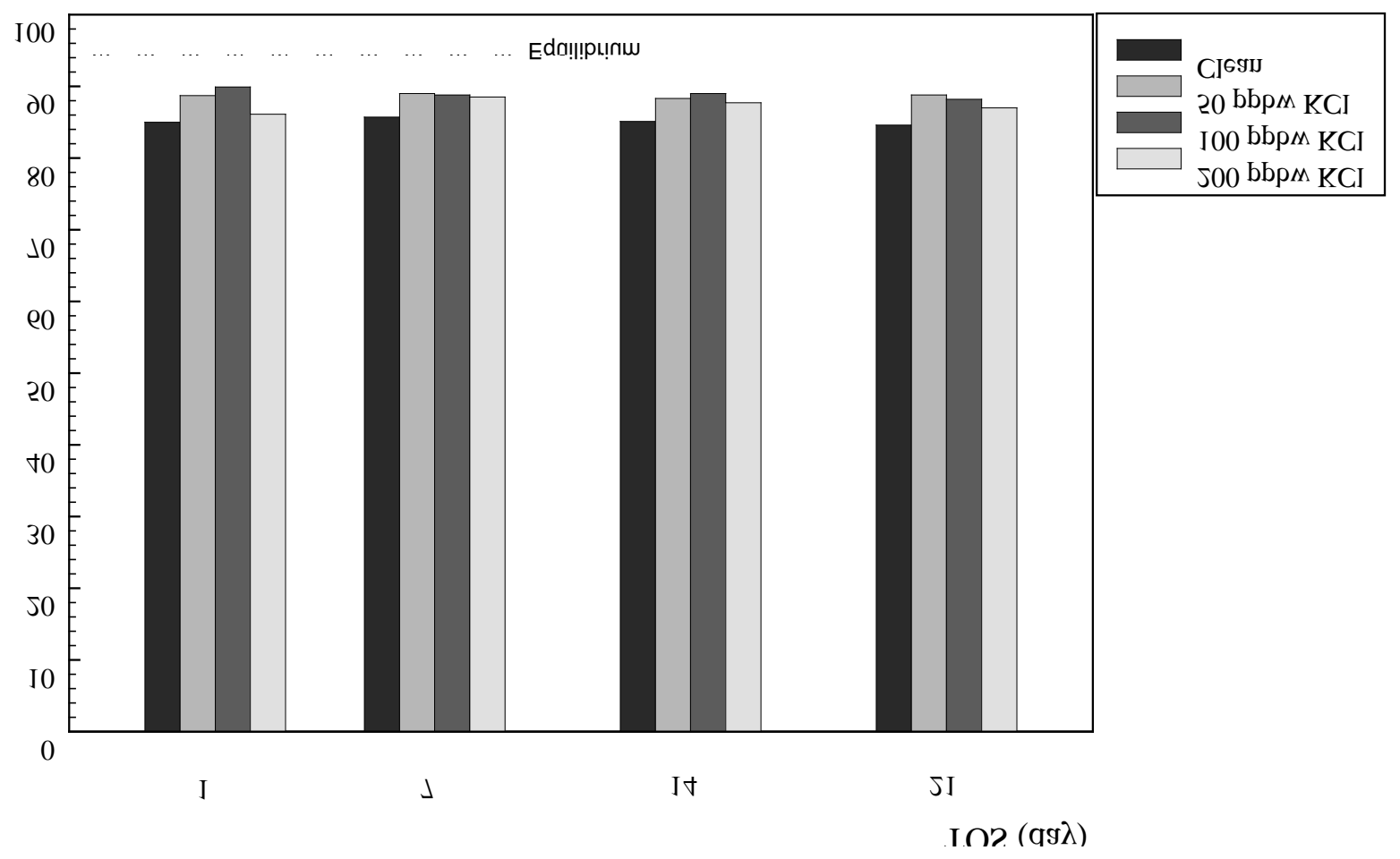

Figure 4 
(4) $\mathrm{NaCl}$ concentration effect on the activity and stability of HTS - Sud-Chemie WGS catalyst versus TOS. Testing conditions: $350^{\circ} \mathrm{C}, 460 \mathrm{psi}, 3250 \mathrm{hr}^{-1}, 240 \mathrm{ml} / \mathrm{min}$ (steam/dry gas ratio of 1 ), catalyst weight of $4 \mathrm{~g}$.

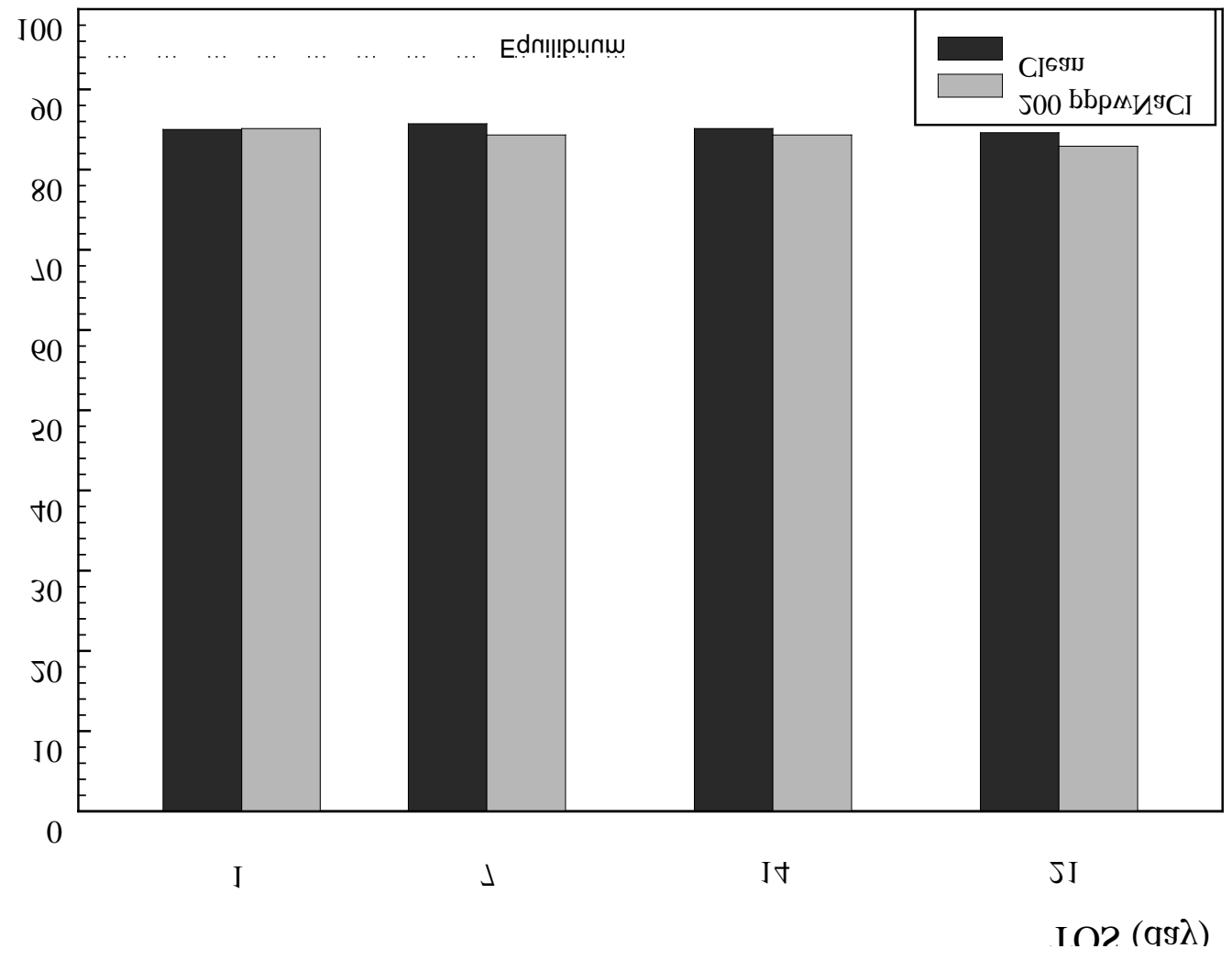

Figure 5 


\section{Investigating the accumulation of $\mathrm{NaCl}$ and $\mathrm{KCl}$ on catalyst surface}

As shown in the previous section, the Süd-Chemie HTS catalyst was found to exhibit good resistance to $\mathrm{KCl}$ and $\mathrm{NaCl}$ poisons in the range of concentrations tested, i.e., up to 200 ppbw, over the time interval examined. However, since the tests were conducted using a fixed bed reactor, there remains the question as whether the contaminants contacted the entire catalyst bed or rather accumulated on the top layer of the catalyst. To investigate this, several downstream water samples, collected from the cold trap during the 200 ppbw KCl poisoning test, were analyzed for $\mathrm{K}^{+}$and $\mathrm{Cl}^{-}$and results are displayed in Table 1. By comparing the concentrations of $\mathrm{K}^{+}$and $\mathrm{Cl}^{-}$in the feed with those collected from the cold trap at different times on-stream (TOS), results indicate that almost all $\mathrm{Cl}^{-}$and most of the $\mathrm{K}^{+}$adsorbed on the catalyst. Examining the mass balance over the catalyst after 21 days TOS, an average of 153 ppmw $\mathrm{K}^{+}$

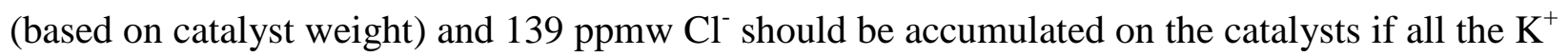
and $\mathrm{Cl}^{-}$ions adsorbed. In order to check if there is a distribution of $\mathrm{K}^{+}$and $\mathrm{Cl}^{-}$ions in the catalyst bed, the 200 ppbw $\mathrm{KCl}$ poisoning test was repeated and the catalyst bed was divided into three layers, with each layer separated by a small volume of glass wool between layers. The catalyst was stable for 21 days of TOS. After that, each catalyst bed was mixed very well and three representative samples from each bed were analyzed for $\mathrm{K}^{+}$and $\mathrm{Cl}^{-}$. We have also analyzed the fresh catalyst to quantify any impurities of $\mathrm{K}^{+}$and $\mathrm{Cl}^{-}$already present in the catalyst prior to poisoning.

Table 2 shows the results of the accumulated $\mathrm{K}^{+}$ion in each catalyst bed after 21 days TOS. The fresh catalyst was found to contain $\mathrm{K}^{+}$impurities with an average value of about 29 ppmw, so this value was subtracted from the measured values obtained for each bed following poisoning. After 21 days of TOS, $\mathrm{K}^{+}$accumulated significantly in both the top and middle beds, 
but little was found to be accumulated in the bottom bed. Considering the $95 \%$ Confidence Interval (CI) calculations, both the calculated $\mathrm{CI}_{\text {upper }}$ and $\mathrm{CI}_{\text {lower }}$ values of the top and the middle beds (see Table 2) were found to be greater than those calculated for the fresh catalyst, consistent with $\mathrm{K}^{+}$accumulation in both beds. In the case of the bottom bed, the $\mathrm{CI}_{\text {lower }}$ was found to be even less than the $\mathrm{CI}_{\text {lower }}$ value of the fresh catalyst; thus, one cannot say with certainty that $\mathrm{K}^{+}$ accumulated in this bed. More datasets for this bed would be required in order to draw a firm conclusion that there was no $\mathrm{K}^{+}$accumulation, because the 95\% confidence interval calculations are more accurate when the datasets contain more data. Nevertheless, the results of Table 2A indicate that $\mathrm{K}^{+}$does accumulate in the top and middle beds.

Table 1: $\mathrm{K}^{+}$and $\mathrm{Cl}^{-}$in the recovered water from the $\mathrm{HTS}$ reaction $-200 \mathrm{ppbw} \mathrm{KCl}$.

\begin{tabular}{|cccc|}
\hline Sample \# & Time (day) & $\mathrm{Cl}^{-}(\mathrm{ppmv})$ & $\mathrm{K}^{+}(\mathrm{ppmv})$ \\
\hline $1^{\mathrm{a}}$ & - & $\mathbf{0 . 0 4}$ & $\mathbf{0 . 0 5}$ \\
$2^{\mathrm{b}}$ & - & $\mathbf{0 . 2 7}$ & $\mathbf{0 . 1 8 8}$ \\
\hline 3 & 8 & 0.02 & 0.087 \\
4 & 15 & 0.01 & 0.081 \\
5 & 19 & 0.03 & 0.078 \\
6 & 21 & 0.02 & 0.077 \\
\hline
\end{tabular}

a: distilled water,

b: Feed, $400 \mathrm{ppb} \mathrm{KCl}$ soln (equivalent to $200 \mathrm{ppbw}$ in the wet gas phase). 
In the case of $\mathrm{Cl}^{-}$(Table 3), it is difficult to draw a conclusion regarding the distribution of $\mathrm{Cl}^{-}$in the three beds. This is due to the fact that the three samples for the fresh catalyst have a wide variation so the average is not reliable. The calculated standard deviation for the results of the three catalyst beds is high, leading to unreliable conclusions. The CI values for the three catalyst beds $\left(\mathrm{CI}_{\text {upper }}\right.$ and $\left.\mathrm{CI}_{\text {lower }}\right)$ overlap with the ones of the fresh catalyst; therefore, a firm conclusion regarding the distribution of $\mathrm{Cl}^{-}$is not possible. Two reasons for these results are considered: (1) it is possible that the $\mathrm{Cl}^{-}$impurity in the fresh sample is not uniform or (2) the analysis technique (ICP) is not accurate. Additional investigation would be required to form a definitive conclusion on this point.

Table 2: Analysis of $\mathrm{K}^{+}$(ppmw) in fresh and spent HTS-WGS (Süd-Chemie) catalyst.

\begin{tabular}{|c|c|c|c|c|c|c|c|c|}
\hline & & & & & \multicolumn{4}{|c|}{ 95\% Confidence interval calculations } \\
\hline Table A & \multicolumn{8}{|c|}{$\mathrm{K}^{+}(\mathrm{ppmw})$} \\
\hline Sample & S1 (ppmw) & S2 (ppmw) & S3 (ppmw) & Average $(\mathrm{X})$ & bed $_{a v g}-$ fresh $_{\text {avg }}$ & $\sigma$ & $C \mathrm{C}_{\text {upper }}=\mathrm{X}+\mathrm{t}^{*} \sigma /(\mathrm{n})^{\wedge} 0.5$ & $C l_{\text {lower }}=X-t^{*} \sigma /(n)^{\wedge} 0.5$ \\
\hline Fresh & 34 & 30.2 & 22.4 & 28.9 & 0.0 & 5.9 & 35.6 & 22.2 \\
\hline Bed - top & 96 & 51.8 & 64.1 & 70.6 & 41.8 & 22.8 & 96.4 & 44.8 \\
\hline Bed - middle & 88 & 60.4 & 72.4 & 73.6 & 44.7 & 13.8 & 89.3 & 57.9 \\
\hline Bed - bottom & 46 & 22.2 & 26.2 & 31.5 & 2.6 & 12.7 & 45.9 & 17.0 \\
\hline
\end{tabular}

Table 3: Analysis of $\mathrm{Cl}^{-}$(ppmw) in fresh and spent HTS-WGS (Süd-Chemie) catalyst.

\begin{tabular}{|c|c|c|c|c|c|c|c|c|}
\hline & & & & & \multicolumn{4}{|c|}{ 95\% Confidence interval calculations } \\
\hline Table B & \multicolumn{8}{|c|}{$\mathrm{Cl}^{-}(\mathrm{ppmw})$} \\
\hline Sample & $\mathrm{S} 1$ (ppmw) & $\mathrm{S} 2$ (ppmw) & S3 (ppmw) & Average $(\mathrm{X})$ & bed $_{\text {avg }}-$ fresh $_{\text {avg }}$ & $\sigma$ & $\mathrm{Cl}_{\text {upper }}=\mathrm{X}+\mathrm{t} * \sigma /(\mathrm{n})^{\wedge} 0.5$ & $\mathrm{Al}_{\text {lower }}=\mathrm{X}-\mathrm{t}^{*} \sigma /(\mathrm{n})^{\wedge} 0.5$ \\
\hline Fresh & 52 & 86.6 & 123.4 & 87.3 & 0.0 & 35.7 & 127.7 & 46.9 \\
\hline Bed - top & 114 & 170 & 102 & 128.7 & 41.3 & 36.3 & 169.7 & 87.6 \\
\hline Bed - middle & 237 & 197 & 100 & 178.0 & 90.7 & 70.4 & 257.7 & 98.3 \\
\hline Bed - bottom & 99 & 12.6 & 19.6 & 43.7 & -43.6 & 48.0 & 98.0 & -10.6 \\
\hline
\end{tabular}




\section{Decoupling the poisoning impact of alkali and halide - sensitivity of Süd-Chemie HTS catalyst to co-fed $\mathrm{KHCO}_{3}, \mathrm{NaHCO}_{3}, \mathrm{HCl}, \mathrm{HBr}$, and $\mathrm{HF}$}

The next aim was to decouple the effect of the alkali from that of the halide and thus, alkali bicarbonates and acid halides were introduced with the HTS feed. First, alkali bicarbonates were investigated in order to assess the impact of alkali. Figure 6 displays the activity and stability of the Süd-Chemie Fe-Cr catalyst during HTS as a function of time on stream (TOS) under 100 ppbw levels of $\mathrm{KHCO}_{3}$ or $\mathrm{NaHCO}_{3}$. With 100 ppbw $\mathrm{KHCO}_{3}$, the catalyst displayed little deactivation during 21 days of TOS, with CO conversion dropping from 85 to $81 \%$. However, in case of 100 ppbw $\mathrm{NaHCO}_{3}$, the deactivation was slightly more pronounced, with CO conversion dropping from 85 to 78\%. In the Year 2009 Annual Topical Report, it was reported previously that $\mathrm{K}^{+}$ions enhance the WGS activity when $\mathrm{KCl}$ solution was used. However, this enhancement was not observed with $\mathrm{KHCO}_{3}$. It is possible that the $\mathrm{HCO}_{3}{ }^{-}$ ions somehow influence the stability of the catalyst because when we compare extents of deactivation $\mathrm{KHCO}_{3}$ and $\mathrm{NaHCO}_{3}$, deactivation was more severe in case of $\mathrm{NaHCO}_{3}$. The $\mathrm{Na}^{+}$ ions did not enhance the WGS activity when $\mathrm{NaCl}$ was utilized (Year 2009 Annual Topical Report). Thus, it is possible that $\mathrm{K}^{+}$ion enhances activity but that the positive effect may be compensated by deactivation from $\mathrm{HCO}_{3}{ }^{-}$ions.

In the case of halide decoupling, the impact of $\mathrm{Cl}^{-}$ions on catalyst stability, by way of cofeeding 100 ppbw $\mathrm{HCl}$, on catalyst stability was investigated separately. Figure 7 displays the activity and stability of the HTS catalyst for the WGS reaction as a function of time on stream (TOS) under $100 \mathrm{ppbw}$ concentration levels of $\mathrm{HCl}, \mathrm{HBr}$, or $\mathrm{HF}$. No significant deactivation of the HT-WGS Süd-Chemie catalyst was observed during the three week interval of testing under the conditions used (e.g., with $\mathrm{HCl}, \mathrm{CO}$ conversion dropped only slightly, from 85 to 82\%). The 
results suggest that the commercial HT-WGS catalyst is relatively resistant to the different halide poisons within concentrations of up to 100 ppbw in the syngas. However, longer testing times would be required to prove this beyond any doubt. Thus, at the concentrations tested, $100 \mathrm{ppbw}$ of $\mathrm{NaCl}, \mathrm{KCl}, \mathrm{KHCO}_{3}, \mathrm{NaHCO}_{3}, \mathrm{HCl}$ induced little deactivation to the Süd-Chemie HTS catalyst over the time interval tested.

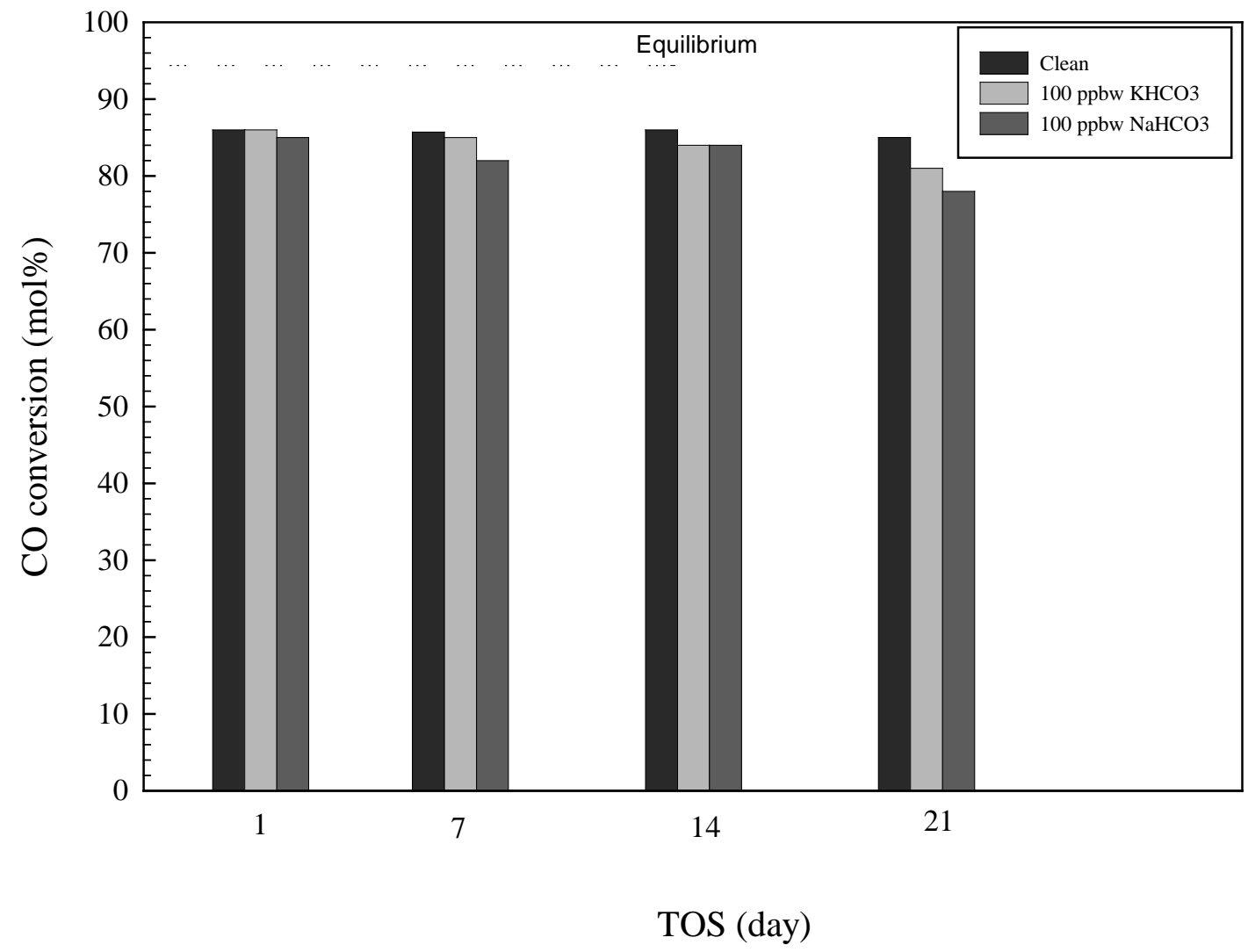

Figure 6: Effect of $\mathrm{KHCO}_{3}$ and $\mathrm{NaHCO}_{3}$ on the activity and stability of Süd-Chemie $\mathrm{Fe}-\mathrm{Cr}$ catalyst during HTS as a function of TOS. Conditions: $350^{\circ} \mathrm{C}, 460 \mathrm{psi}, 3250 \mathrm{hr}^{-1}, 240 \mathrm{ml} / \mathrm{min}$ (steam/dry gas ratio of 1 ), catalyst weight of $4 \mathrm{~g}$. 


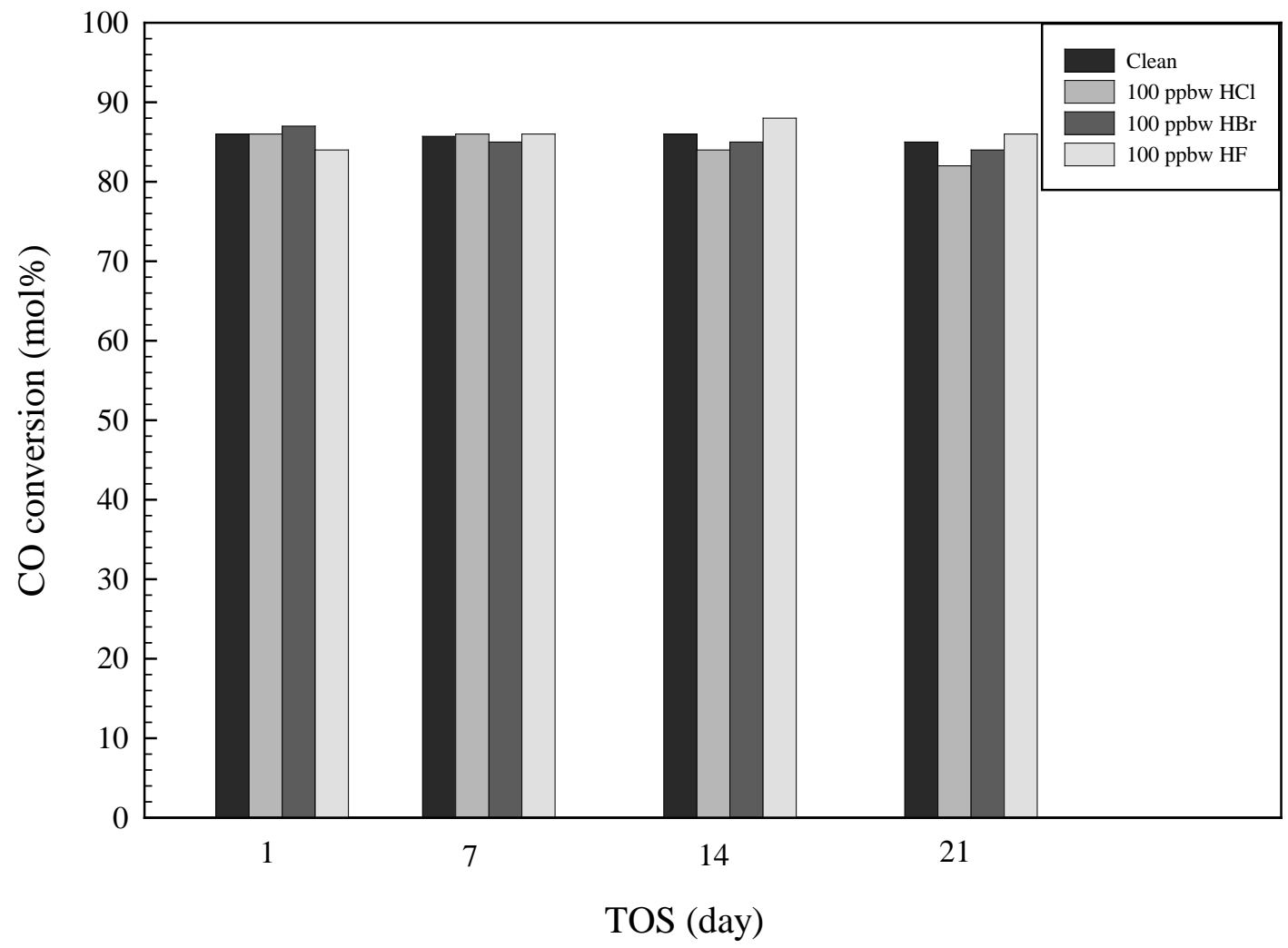

Figure 7: Effect of $\mathrm{HCl}, \mathrm{HBr}$, and $\mathrm{HF}$ on the activity and stability of Süd-Chemie Fe-Cr catalyst during HTS as a function of TOS. Conditions: $350^{\circ} \mathrm{C}, 460 \mathrm{psi}, 3250 \mathrm{hr}^{-1}, 240 \mathrm{ml} / \mathrm{min}$ (steam/dry gas ratio of 1 ), catalyst weight of $4 \mathrm{~g}$. 
4. Impact of additional gasification byproducts - sensitivity of Süd-Chemie HTS catalyst to co-fed $\mathrm{H}_{2} \mathrm{~S}, \mathrm{NH}_{3}$, and $\mathrm{H}_{2} \mathrm{~S}$ combined with $\mathrm{NH}_{3}$

Figure 8 shows the effect of 1 ppmv $\mathrm{H}_{2} \mathrm{~S}$ poisoning levels on the performance of the HTS catalyst. Again, no significant deactivation was observed during a time interval of three weeks.

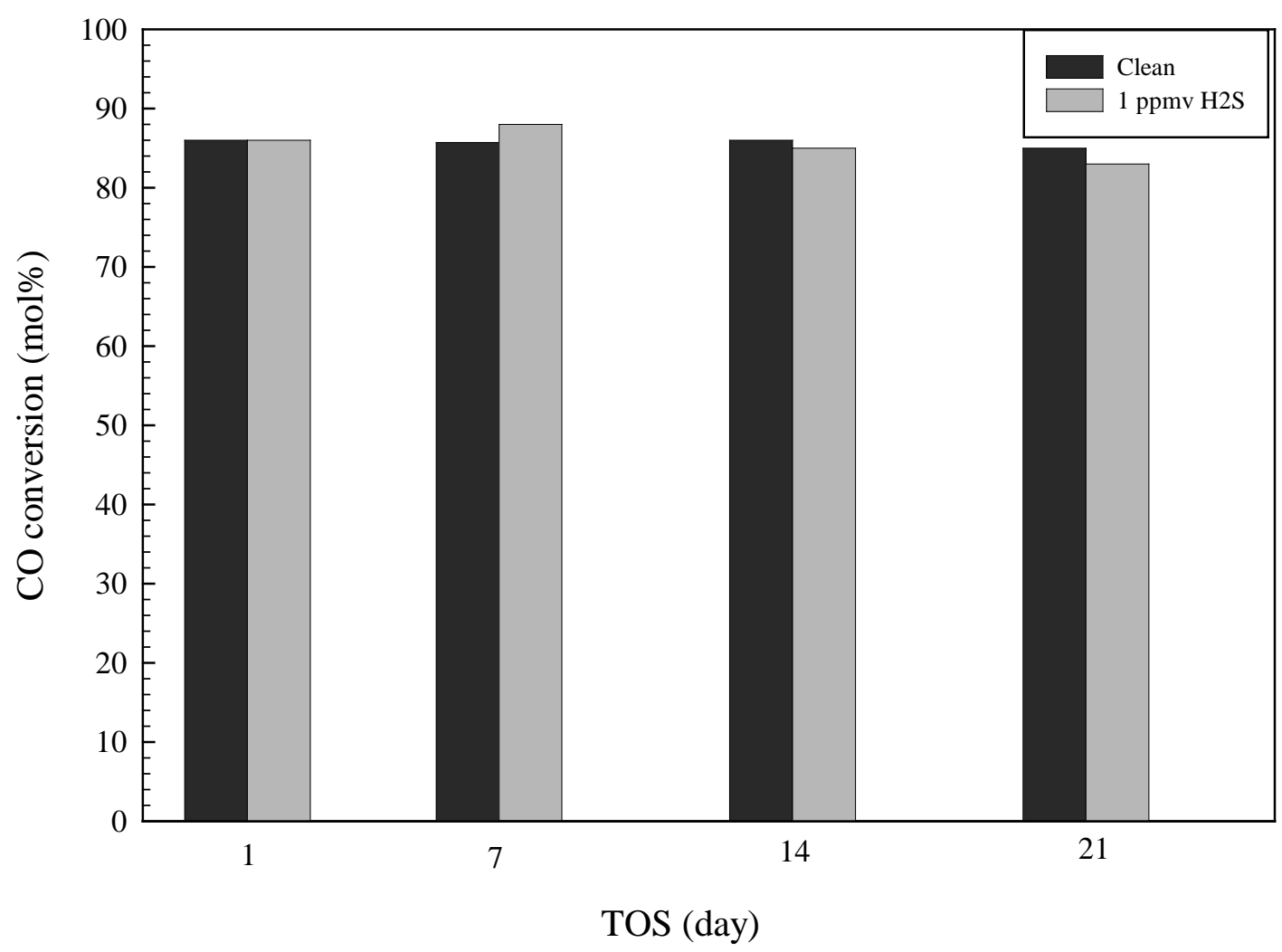

Figure 8: Effect of $\mathrm{H}_{2} \mathrm{~S}$ addition to the activity and stability of the Süd-Chemie Fe-Cr catalyst during HTS as a function of TOS. Conditions: $350^{\circ} \mathrm{C}, 460 \mathrm{psi}, 3250 \mathrm{hr}^{-1}, 240 \mathrm{ml} / \mathrm{min}$ (steam/dry gas ratio of 1 ), catalyst weight of $4 \mathrm{~g}$. 
Next, the effect of $\mathrm{NH}_{3}$ and a combination of $\mathrm{NH}_{3}$ and $\mathrm{H}_{2} \mathrm{~S}$ poisoning on the stability of the Süd-Chemie catalyst during HTS was investigated. The concentrations of $\mathrm{NH}_{3}$ used were 2, 5, 10 and $12 \mathrm{ppm}$, whereas that of $\mathrm{NH}_{3}$ and $\mathrm{H}_{2} \mathrm{~S}$ varied as follows:

\begin{tabular}{cc}
\hline $\mathrm{NH}_{3}(\mathrm{ppm})$ & $\mathrm{H}_{2} \mathrm{~S}(\mathrm{ppm})$ \\
\hline 2 & 0.2 \\
2 & 0.4 \\
4 & 0.4 \\
4 & 0.6 \\
6 & 0.6 \\
6 & 0.8 \\
\hline
\end{tabular}

The conditions used were as follows: temperature, $350^{\circ} \mathrm{C}$; pressure, $460 \mathrm{psi}$; and space velocity, $3250 \mathrm{hr}^{-1}$.

Figure 9 shows the activity and stability of the HTS catalyst for the WGS reaction as a function of time on stream (TOS). The concentration levels of $\mathrm{NH}_{3}$ used were: 2, 5, 10 and 12 ppm respectively. The results imply that the commercial HTS catalyst is somewhat resistant to $\mathrm{NH}_{3}$ poisoning within the concentration levels of up to $5 \mathrm{ppm}$ of testing under the conditions used. However, in examining the effect of $\mathrm{NH}_{3}$ poisoning at higher concentration levels e.g. 12 ppm in the syngas, a slight decrease in catalytic activity was observed from $88 \%$ to $85 \%$ as displayed (Figure 9), longer testing times and high concentration would be required to explore further the poisoning effect on HTS catalyst.

Figure 10 investigates the effect of a combination of $\left(\mathrm{NH}_{3}\right.$ and $\left.\mathrm{H}_{2} \mathrm{~S}\right)$ poisoning levels on the performance of the HTS catalyst. No significant deactivation was observed during a time interval of three weeks. A slight decrease in catalytic activity was observed at concentration levels of $6 \mathrm{ppm} \mathrm{NH}_{3}$ and $0.6 \mathrm{ppm} \mathrm{H}_{2} \mathrm{~S}$ from $88 \%$ to $87 \%$. 


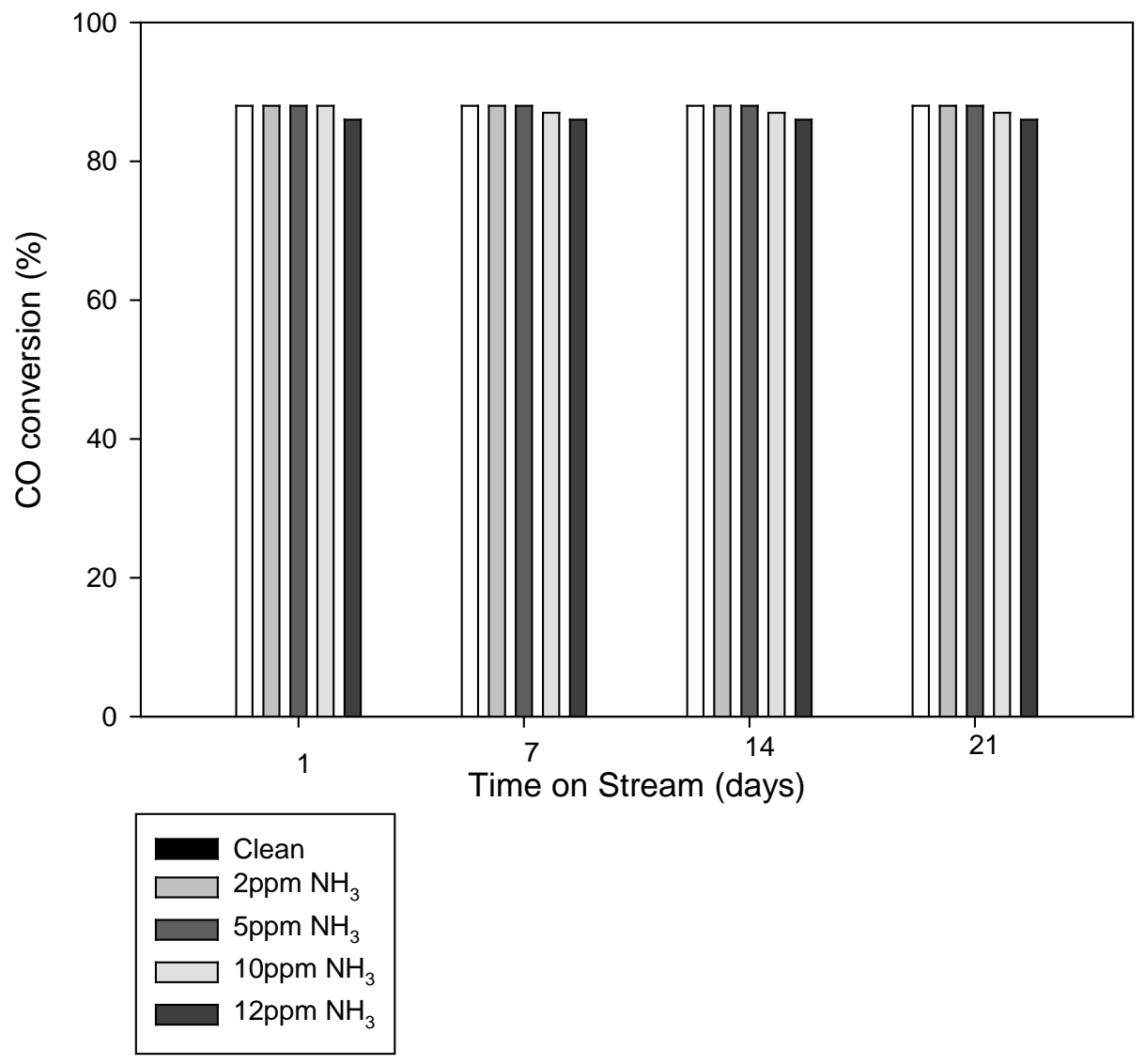

Figure 9: $\mathrm{NH}_{3}$ poisoning effect on the activity and stability of HTS - Süd-Chemie WGS catalyst showing CO conversion (\%) vs. TOS (days). Conditions employed: $350^{\circ} \mathrm{C}, 460 \mathrm{psi}, 3250 \mathrm{hr}^{-1}$, $240 \mathrm{ml} / \mathrm{min}$ (steam/dry gas ratio of 1), catalyst weight of $4 \mathrm{~g}$. 


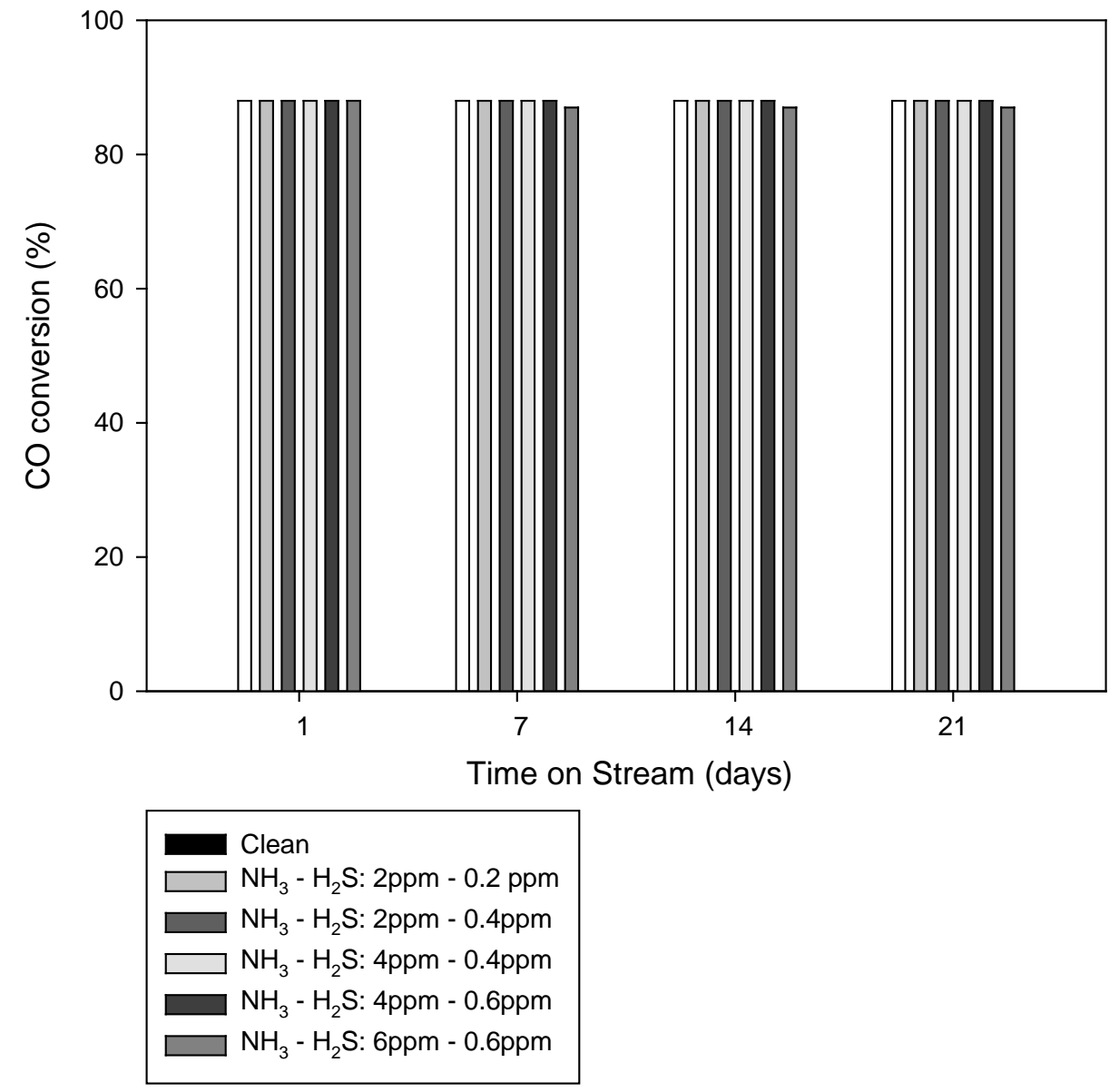

Figure 10: Effect of $\mathrm{NH}_{3}$ and $\mathrm{H}_{2} \mathrm{~S}$ addition to the activity and stability of the Süd-Chemie HTSWGS catalyst as a function of time on stream. Conditions employed: $350^{\circ} \mathrm{C}, 460 \mathrm{psi}, 3250 \mathrm{hr}^{-1}$, $240 \mathrm{ml} / \mathrm{min}$ (steam/dry gas ratio of 1 ), catalyst weight of $4 \mathrm{~g}$. 
B. FT reaction: Sensitivity of an iron catalyst to co-fed gasification byproduct contaminants, including $\mathrm{KCl}, \mathrm{NaCl}, \mathrm{NaHCO}_{3}, \mathrm{KHCO}_{3}, \mathrm{HCl}, \mathrm{HBr}$, and $\mathrm{NH}_{4} \mathrm{NO}_{3}$

\section{Sensitivity of an iron catalyst to alkali halides $-\mathrm{KCl}$ and $\mathrm{NaCl}$}

The sensitivity of the iron catalyst to alkali halide compounds was tested by subjecting the catalyst to FT feeds containing $\mathrm{KCl}$ and $\mathrm{NaCl}$. The catalyst was first subjected to a clean feed, and then switched to a feed containing $100 \mathrm{ppbw}$ of $\mathrm{KCl}$. Later in the run, the concentration was increased to $400 \mathrm{ppbw} \mathrm{KCl}$. The reactor conditions were: $270{ }^{\circ} \mathrm{C}, 175$ psig $\left(\mathrm{CO}+\mathrm{H}_{2}\right), \mathrm{H}_{2} / \mathrm{CO}=0.77$, and $\mathrm{SV}_{\mathrm{CO}+\mathrm{H} 2}=10 \mathrm{Nl} / \mathrm{g}$-cat/h. A typical induction period was observed for the first $75 \mathrm{~h}$ where carburization of the catalyst continued to occur. Note that unlike cobalt catalysts, where the active sites are proposed to be surface cobalt metal atoms [2], iron carbide is deemed to be a necessary component in the working iron catalyst [3]. The catalyst reached a maximum of about 75\% CO conversion. After $~ 165$ hours onstream, 100 ppbw $\mathrm{KCl}$ was added and the catalyst was tested at this condition for $\sim 135$ hours. No significant deactivation above the baseline condition was detected (Figure 11, top). However, increasing the concentration to 400 ppbw $\mathrm{KCl}$ led to a more severe deactivation, where the CO conversion dropped steadily from $\sim 68 \%$ to $62 \%$ (Figure 11 , top) over $\sim 80 \mathrm{~h}$. Little impact on $\mathrm{C}_{5}+$ and $\mathrm{C}_{1}$ selectivities (Figure 9, middle) was observed, although a slight increase in $\mathrm{CO}_{2}$ selectivity was detected during the course of the run (Figure 9, bottom).

A similar test was carried out for $\mathrm{NaCl}$. However, no significant deactivation beyond the clean baseline condition was observed at either 100 ppbw or 400 ppbw levels of $\mathrm{NaCl}$ (Figure 12, top). Little effect on $\mathrm{C}_{5}+$ and $\mathrm{C}_{1}$ selectivities (Figure 12, middle) was observed, although, as with $\mathrm{KCl}$, a slight increase in $\mathrm{CO}_{2}$ selectivity was detected during the course of the run (Figure 10, bottom). 


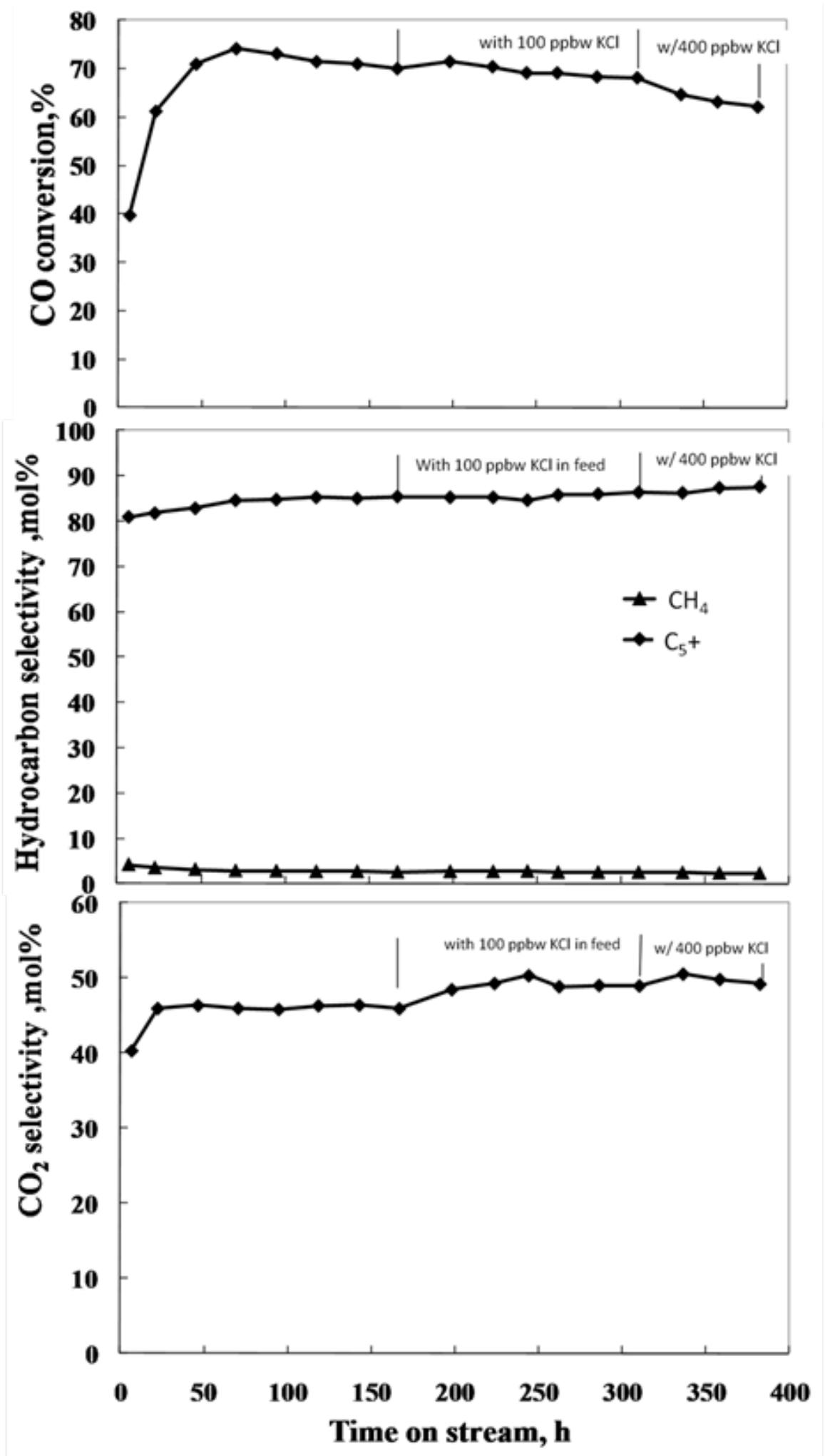

Figure 11: Effect of $\mathrm{KCl}$ (100 -400 ppbw in feed) on CO conversion (Top), $\mathrm{CH}_{4}$ and $\mathrm{C}_{5+}$ selectivities (Middle) on $100 \mathrm{Fe} / 5.1 \mathrm{Si} / 3 \mathrm{~K} / 2 \mathrm{Cu}$ (GJ457) and $\mathrm{CO}_{2}$ selectivity (Bottom) on 100Fe/5.1Si/3K/2Cu (GJ457). Test conditions: $270{ }^{\circ} \mathrm{C}, 175 \mathrm{psig}\left(\mathrm{CO}+\mathrm{H}_{2}\right), \mathrm{H}_{2} / \mathrm{CO}=0.77$, $\mathrm{SV}_{\mathrm{CO}+\mathrm{H} 2}=10 \mathrm{Nl} / \mathrm{g}-\mathrm{Cat} / \mathrm{h}$. 


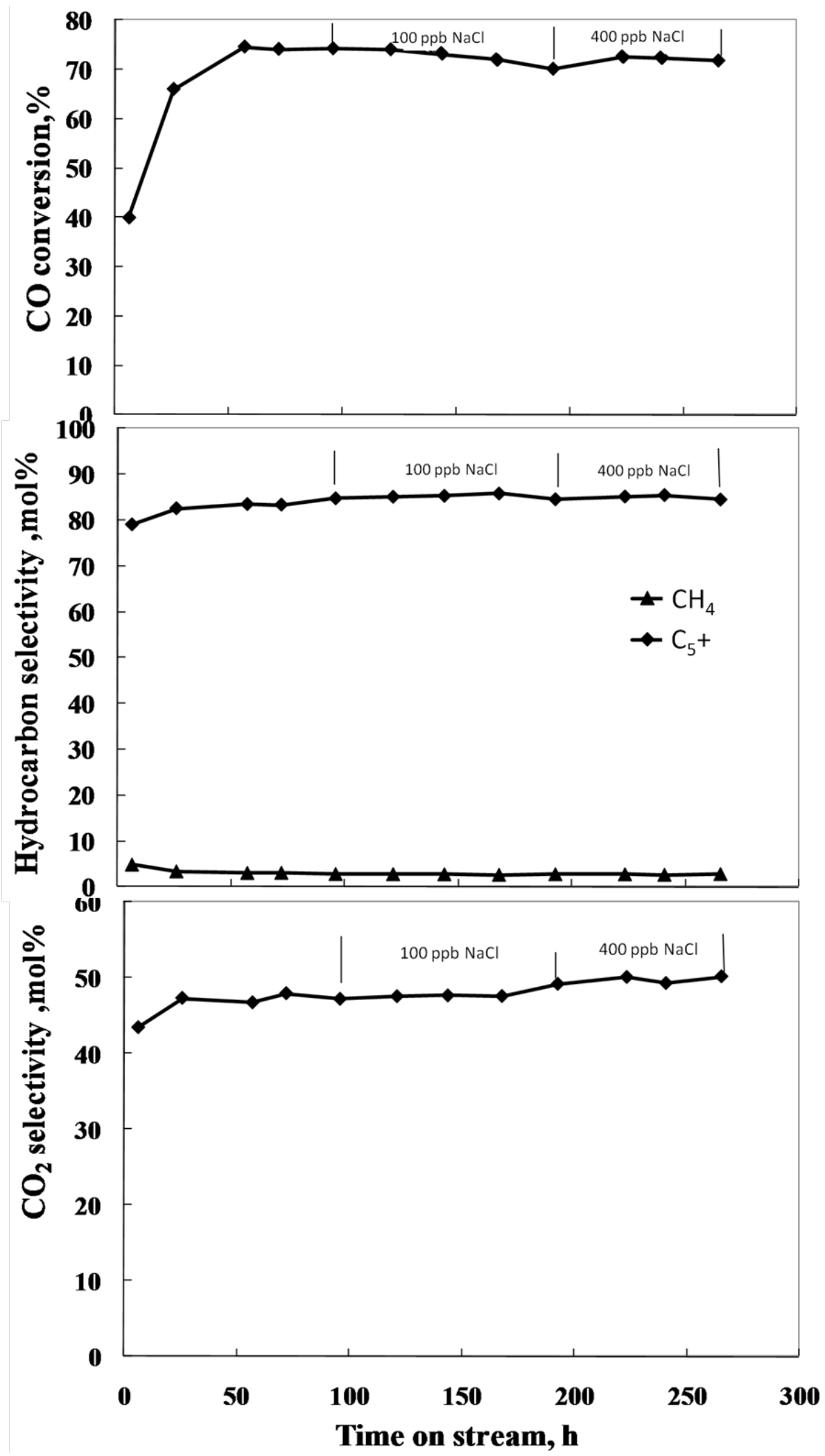

Figure 12: Effect of $\mathrm{NaCl}\left(100-400 \mathrm{ppbw}\right.$ in feed) on $\mathrm{CO}$ conversion (Top), $\mathrm{CH}_{4}$ and $\mathrm{C}_{5+}$ selectivities (Middle) on 100Fe/5.1Si/3K/2Cu (GJ457) and $\mathrm{CO}_{2}$ selectivity (Bottom) on 100Fe/5.1Si/3K/2Cu (GJ457). Test conditions: $270{ }^{\circ} \mathrm{C}, 175 \mathrm{psig}\left(\mathrm{CO}+\mathrm{H}_{2}\right), \mathrm{H}_{2} / \mathrm{CO}=0.77$, $\mathrm{SV}_{\mathrm{CO}+\mathrm{H} 2}=10 \mathrm{Nl} / \mathrm{g}-\mathrm{cat} / \mathrm{h}$. 


\section{Decoupling the poisoning impact of alkali and halide - sensitivity of Fe-based FT catalyst to co-fed $\mathrm{KHCO}_{3}, \mathrm{NaHCO}_{3}, \mathrm{HCl}$, and $\mathrm{HBr}$}

The next aim was to decouple the effect of the alkali from the halide and to accomplish this, alkali bicarbonate and acid halides were co-fed with the syngas. After the initial induction period, the catalyst was first subjected to a clean feed, and then switched to a feed containing 100 ppbw of $\mathrm{NaHCO}_{3}$; later in the run the concentration was increased to 400 ppbw $\mathrm{NaHCO}_{3}$ and finally, to $40 \mathrm{ppm} \mathrm{KHCO}_{3}$. No significant deactivation was observed with either 100 ppbw or 400 ppbw $\mathrm{NaHCO}_{3}$, but when the level was increased to $40 \mathrm{ppm}$, significant deactivation of the catalyst was observed, with the conversion level dropping from $\sim 68 \%$ to $63 \%$ in about 50 hours (Figure 13).

With $\mathrm{KHCO}_{3}$, after $~ 95 \mathrm{~h}$ of testing with a clean feed, 100 ppbw $\mathrm{KHCO}_{3}$ was added and the catalyst was tested at this condition for $\sim 70 \mathrm{~h}$. No significant deactivation above the baseline condition was detected (Figure 14, top). The same was true when the concentration of $\mathrm{KHCO}_{3}$ was raised to 400

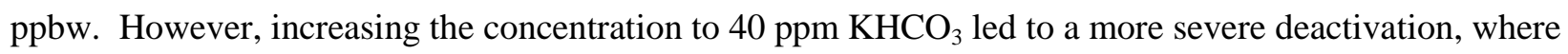
the CO conversion dropped steadily from $\sim 66 \%$ to 57\% (Figure 14, top) over an approximately $150 \mathrm{~h}$ time period. Very little effect on $\mathrm{C}_{5}+$ and $\mathrm{C}_{1}$ selectivities (Figure 14, middle) was observed, although a slight increase in $\mathrm{CO}_{2}$ selectivity was detected during the course of the run (Figure 14, bottom). Thus, the general trends between $\mathrm{NaHCO}_{3}$ and $\mathrm{KHCO}_{3}$ addition were similar. 


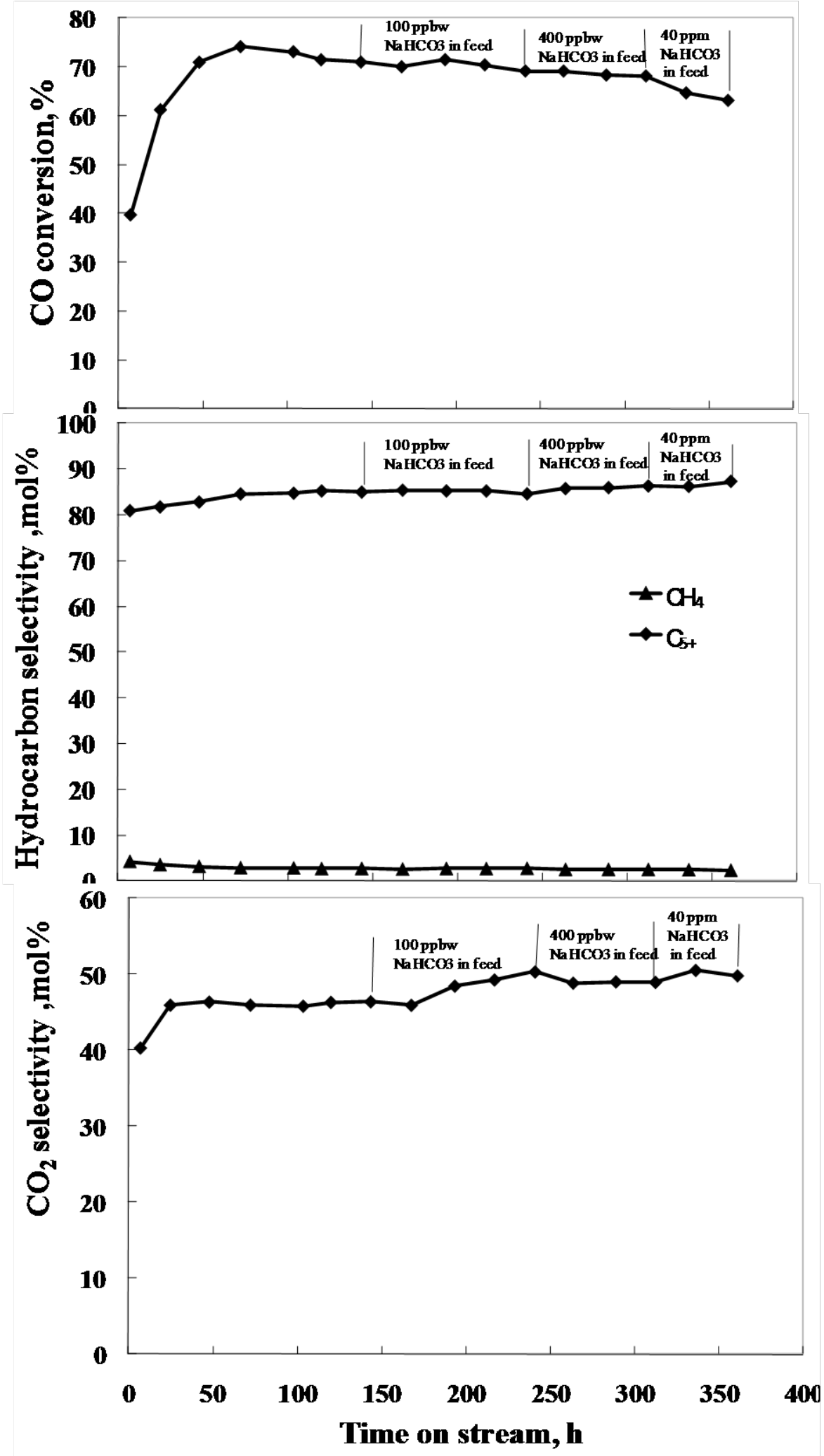

Figure 13: Effect of $\mathrm{NaHCO}_{3}$ (100 ppbw-40 ppm in feed) on CO conversion (Top), $\mathrm{CH}_{4}$ and $\mathrm{C}_{5+}$ selectivities (Middle) on 100Fe/5.1Si/3K/2Cu (GJ457) and $\mathrm{CO}_{2}$ selectivity (Bottom) on 100Fe/5.1Si/3K/2Cu (GJ457). Test conditions: $270{ }^{\circ} \mathrm{C}, 175 \mathrm{psig}\left(\mathrm{CO}+\mathrm{H}_{2}\right), \mathrm{H}_{2} / \mathrm{CO}=0.77$, $\mathrm{SV}_{\mathrm{CO}+\mathrm{H} 2}=10 \mathrm{Nl} / \mathrm{g}-\mathrm{cat} / \mathrm{h}$. 

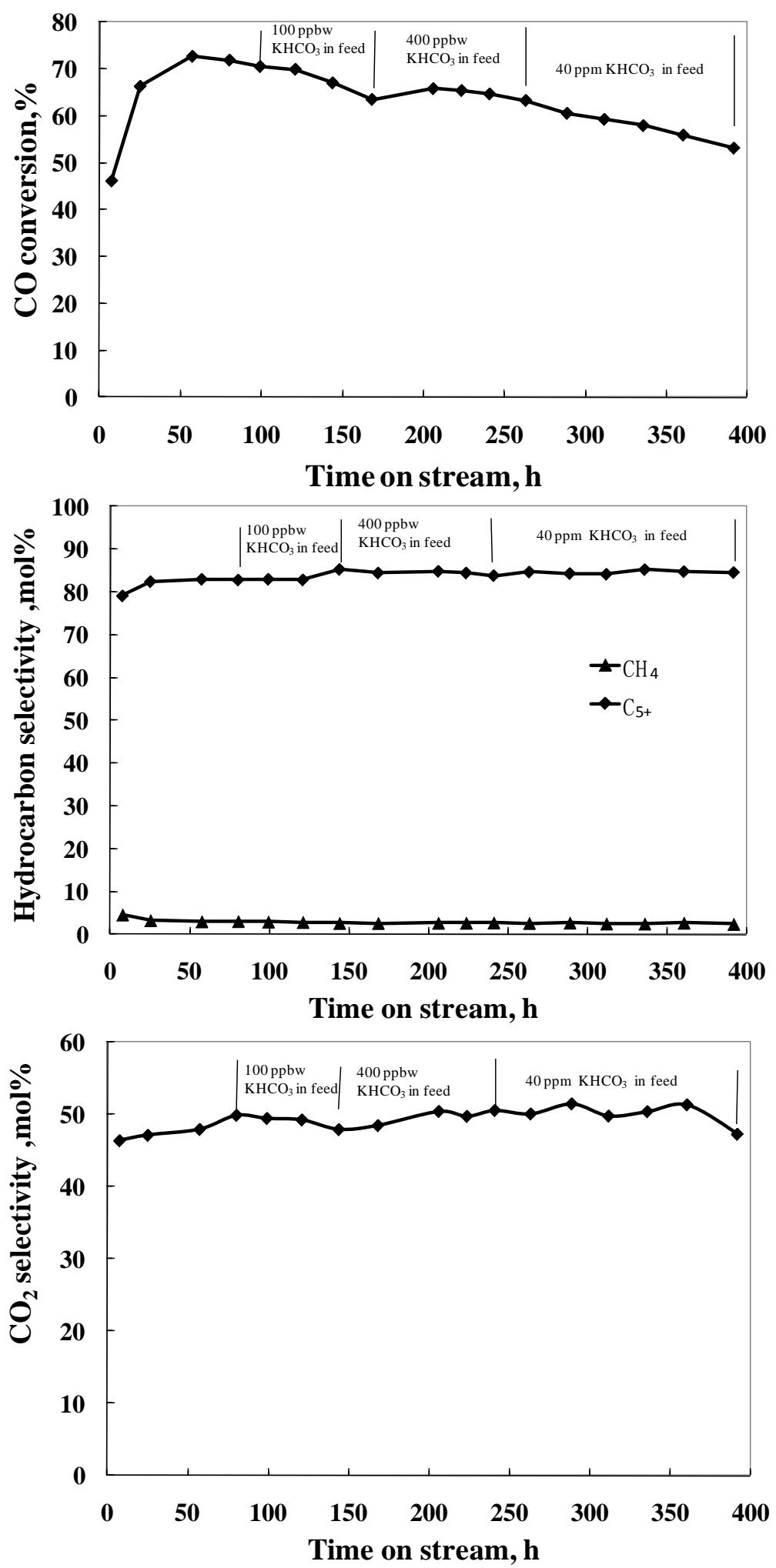

Figure 14: Effect of $\mathrm{KHCO}_{3}$ (100 ppbw - 40 ppm in feed) on CO conversion (Top), $\mathrm{CH}_{4}$ and $\mathrm{C}_{5+}$ selectivities (Middle) and $\mathrm{CO}_{2}$ selectivity (Bottom) over 100Fe/5.1Si/3K/2Cu (GJ457). Test conditions: $270{ }^{\circ} \mathrm{C}, 175$ psig $\left(\mathrm{CO}+\mathrm{H}_{2}\right), \mathrm{H}_{2} / \mathrm{CO}=0.77, \mathrm{SV}_{\mathrm{CO}+\mathrm{H} 2}=10 \mathrm{Nl} / \mathrm{g}$-cat/h. Run ID = MAW188. 
To decouple the impact of the halide, the sensitivity of the iron catalyst was tested by subjecting the catalyst to FT feeds containing, separately, $\mathrm{HCl}$ and $\mathrm{HBr}$. The catalyst was first subjected to a clean feed, and then switched to a feed containing either $\mathrm{HCl}$ or $\mathrm{HBr}$ at $100 \mathrm{ppbw}$; later in the run, the concentration was increased to $400 \mathrm{ppbw} \mathrm{HCl}$ and finally, to $40 \mathrm{ppm}$. The reactor conditions were: $270{ }^{\circ} \mathrm{C}, 175 \mathrm{psig}\left(\mathrm{CO}+\mathrm{H}_{2}\right), \mathrm{H}_{2} / \mathrm{CO}=0.77$, and $\mathrm{SV}_{\mathrm{CO}+\mathrm{H} 2}=10 \mathrm{Nl} / \mathrm{g}$-cat $/ \mathrm{h}$.

For the $\mathrm{HCl}$ co-feeding run, the typical induction period was observed for the first $50 \mathrm{~h}$ and the conversion level reach a maximum of $\sim 75 \%$. After $~ 95$ hours onstream, 100 ppbw of $\mathrm{HCl}$ was added and the catalyst was tested at this condition for $\sim 80$ hours. No significant deactivation above the baseline condition was detected (Figure 15, top). Increasing the concentration to $400 \mathrm{ppbw} \mathrm{HCl}$ did not significantly impact the catalyst either (Figure 15, top) over an approximately 65 hour time period. Very little effect on $\mathrm{C}_{5}+$ and $\mathrm{C}_{1}$ selectivities (Figure 15, middle) was observed, although a slight increase in $\mathrm{CO}_{2}$ selectivity was detected (Figure 15, bottom). Increasing the $\mathrm{HCl}$ level to $40 \mathrm{ppm} \mathrm{HCl}$, however, led to significant deactivation of the catalyst, but the CO conversion level did eventually level off at 20\%. At time on stream $\sim 295 \mathrm{~h}$, the CO conversion level was still $\sim 72 \%$. However, at $\sim 430$ hours, the conversion had leveled off at $20 \%$. During this final poisoning period, the hydrocarbon $\mathrm{C}_{5}+$ selectivity decreased from $\sim 85 \%$ to $\sim 70 \%$, and the $\mathrm{C}_{1}$ selectivity increased to $\sim 5 \% . \mathrm{CO}_{2}$ selectivity was impacted significantly, decreasing from $\sim 47 \%$ to $\sim 12 \%$.

For the $\mathrm{HBr}$ co-feeding run, following the typical induction period, conversion reached a maximum of $\sim 73 \%$ CO. After $\sim 65$ hours onstream, 100 ppbw of $\mathrm{HBr}$ was added and the catalyst was tested at this condition for $\sim 65$ hours. Only slight deactivation occurred during this interval (Figure 16, top). However, when the concentration was increased to $400 \mathrm{ppbw} \mathrm{HBr}$, the CO conversion rapidly ( 60 hours) decreased and leveled off at $\sim 55 \%$. The pump was then switched off to allow the baseline to stabilize ( $\sim 0$ hours). The catalyst was then again subjected to $400 \mathrm{ppbw} \mathrm{HBr}$ and, this time, the catalyst did not display any significant deactivation over 100 hours. Boosting the concentration to $40 \mathrm{ppm}$ led to severe deactivation, with CO conversion decreasing from 52\% to 32\% in 110 hours. Switching off the 
$\mathrm{HBr}$ pump after the severe condition, CO conversion stabilized between 30 and $35 \%$. An impact on $\mathrm{C}_{5}{ }^{+}$ (Figure 16, middle) was mainly observed during the first poisoning interval with 400 ppbw $\mathrm{HBr}$ (decrease of $\mathrm{C}_{5}+$ from $\sim 82 \%$ to $72 \%$ ). The $\mathrm{C}_{1}$ selectivity gradually increased to $\sim 5 \%$ during the course of the entire run. $\mathrm{CO}_{2}$ selectivity was most significantly affected during co-feeding with $40 \mathrm{ppm} \mathrm{HBr}$, where it dropped from $\sim 45 \%$ to 33\% (Figure 16, bottom). 


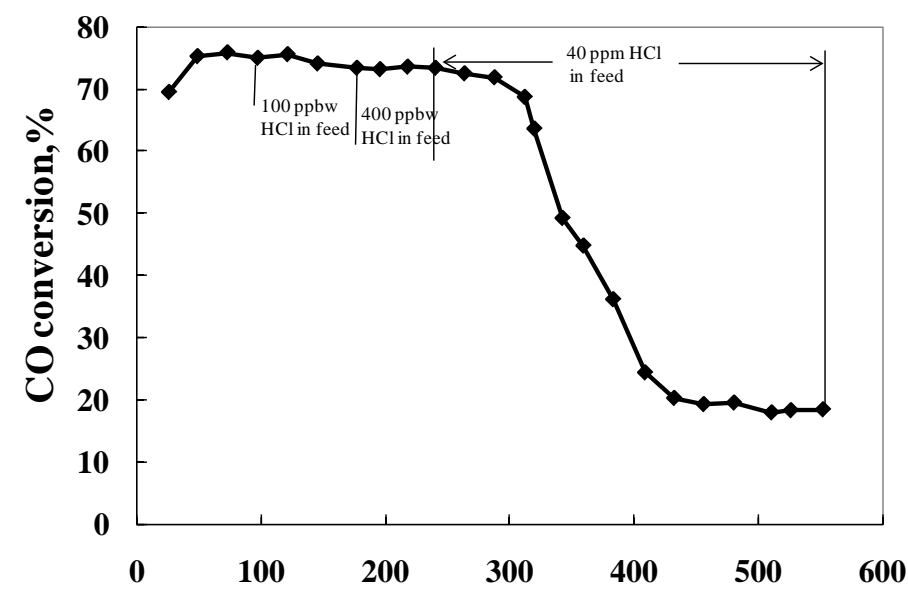

Time on stream. h
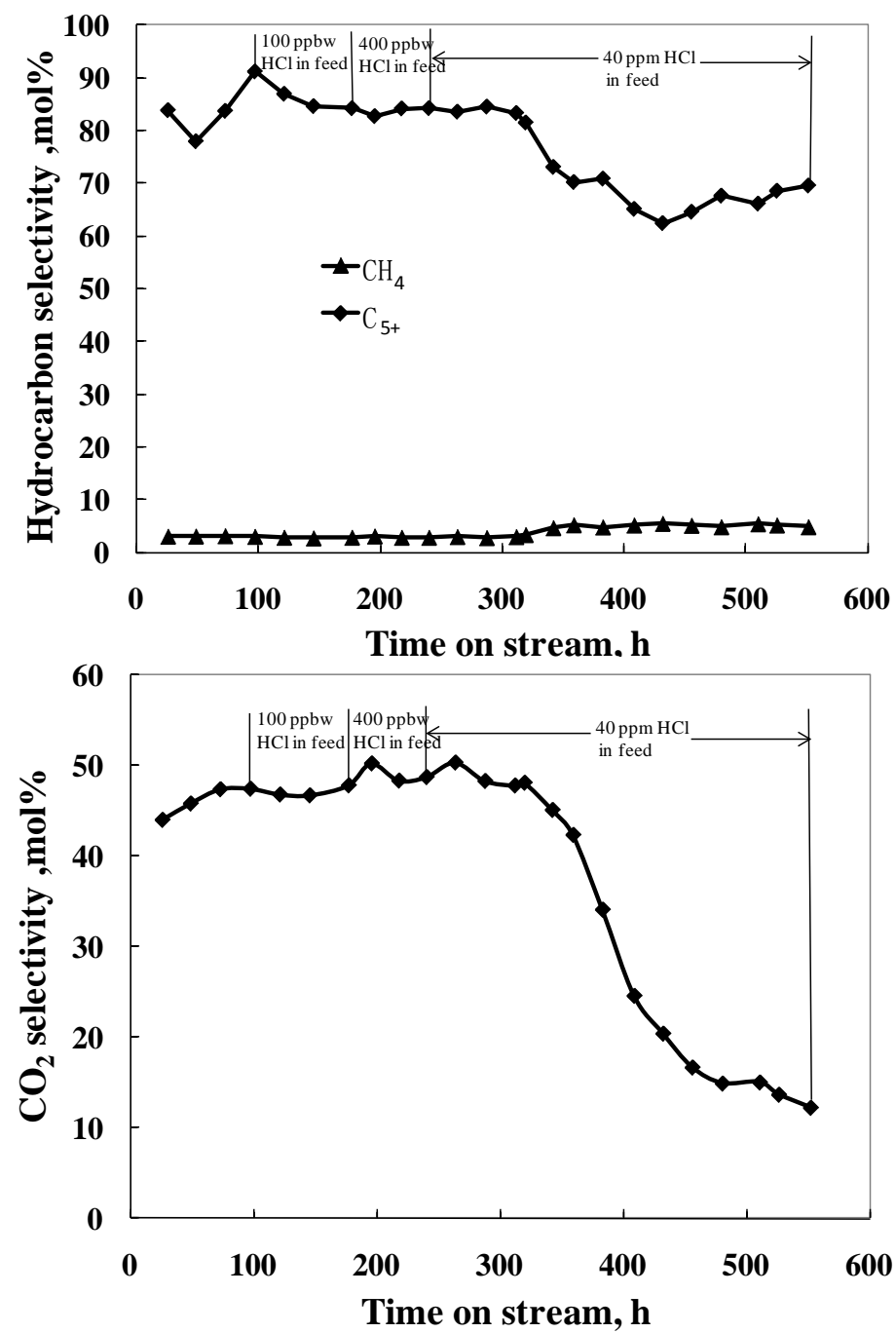

Figure 15 Effect of $\mathrm{HCl}$ (100 ppbw-40 ppm in feed) on $\mathrm{CO}$ conversion (Top), $\mathrm{CH}_{4}$ and $\mathrm{C}_{5+}$ selectivities (Middle) and $\mathrm{CO}_{2}$ selectivity (Bottom) on $100 \mathrm{Fe} / 5.1 \mathrm{Si} / 3 \mathrm{~K} / 2 \mathrm{Cu}$ (GJ457).

Test conditions: $270{ }^{\circ} \mathrm{C}, 175 \mathrm{psig}\left(\mathrm{CO}+\mathrm{H}_{2}\right), \mathrm{H}_{2} / \mathrm{CO}=0.77, \mathrm{SV}_{\mathrm{CO}+\mathrm{H} 2}=10 \mathrm{Nl} / \mathrm{g}$-cat $/ \mathrm{h}$ 

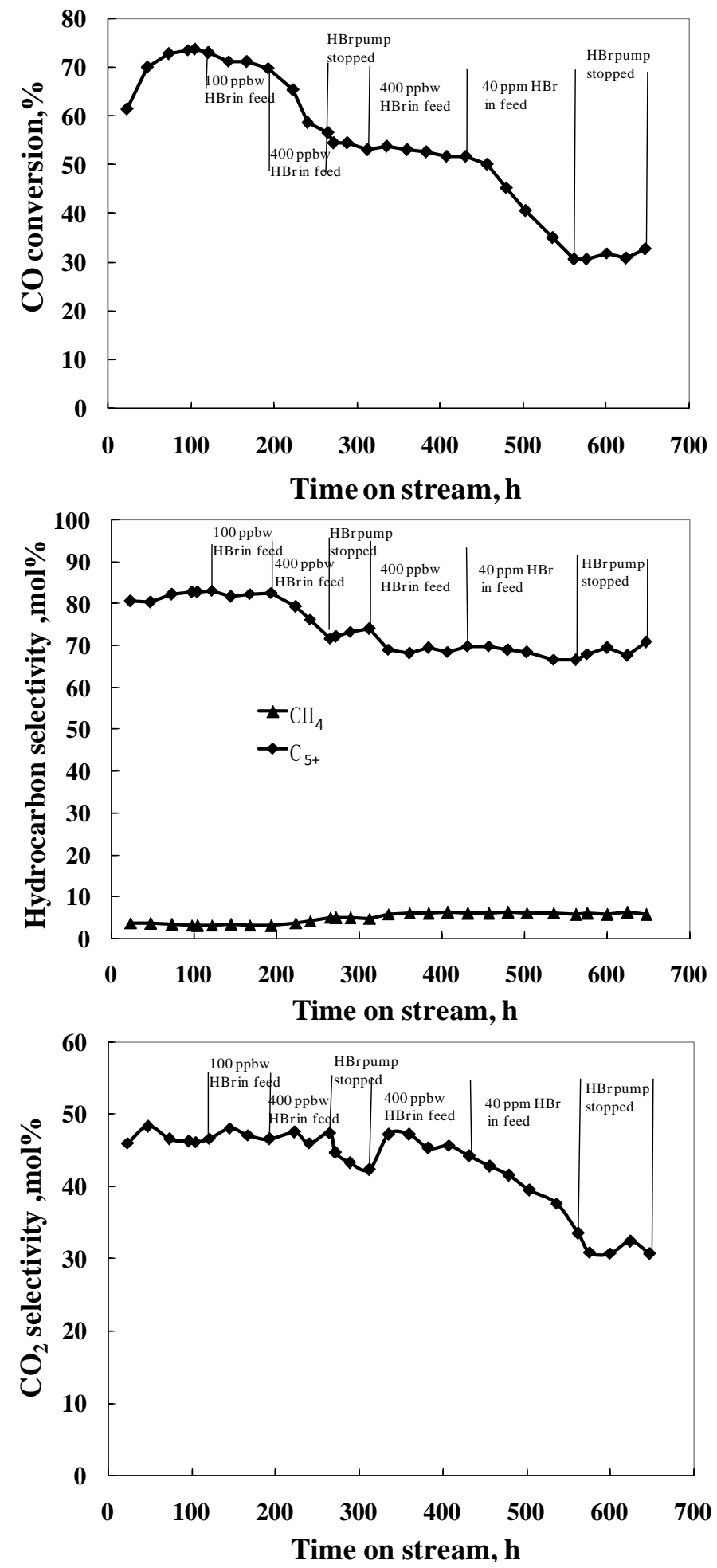

Figure 16 Effect of $\mathrm{HBr}$ (100 ppbw-40 ppm in feed) on CO conversion (Top), $\mathrm{CH}_{4}$ and $\mathrm{C}_{5^{+}}$selectivities (Middle) and $\mathrm{CO}_{2}$ selectivity (Bottom) on $100 \mathrm{Fe} / 5.1 \mathrm{Si} / 3 \mathrm{~K} / 2 \mathrm{Cu}(\mathrm{GJ} 457)$.

Test conditions: $270{ }^{\circ} \mathrm{C}, 175 \mathrm{psig}\left(\mathrm{CO}+\mathrm{H}_{2}\right), \mathrm{H}_{2} / \mathrm{CO}=0.77, \mathrm{SV}_{\mathrm{CO}+\mathrm{H} 2}=10 \mathrm{Nl} / \mathrm{g}$-cat $/ \mathrm{h}$. 


\section{Impact of additional gasification byproducts - sensitivity of an Fe-based FT catalyst to co-fed $\mathrm{NH}_{4} \mathrm{NO}_{3}$}

Figures 17 - 24 show the effect of varying levels of $\mathrm{NH}_{4} \mathrm{NO}_{3}$ over the Fe-based catalyst. The run lasted $2161 \mathrm{~h}$. After the induction period, 100 ppbw of $\mathrm{NH}_{4} \mathrm{NO}_{3}$ was added between 170 and $240 \mathrm{~h}$ of time onstream (Figure 17). During this period, the catalyst exhibited good stability. No significant deactivation was observed with addition of 400 ppbw $\mathrm{NH}_{4} \mathrm{NO}_{3}$ between 240 and $432 \mathrm{~h}$ of TOS (Figure 18). A significant decline in activity was noted with 1 ppmw $\mathrm{NH}_{4} \mathrm{NO}_{3}$ addition, but it is unclear whether the drop was due to actual catalyst deactivation or due to an interruption in power (Figure 19). We believe that the latter occurred, as the catalyst nearly recovered activity between 866 and $1128 \mathrm{~h}$ onstream. Moreover, increasing the concentration to $10 \mathrm{ppmw} \mathrm{NH}_{4} \mathrm{NO}_{3}$, no significant catalyst deactivation was observed between a TOS of 1128 to $1321 \mathrm{~h}$ (Figure 20). Addition of $40 \mathrm{ppmw} \mathrm{NH}_{4} \mathrm{NO}_{3}$, however, led to a measurable decline in catalyst activity, between 1321 and $1488 \mathrm{~h}$ (Figure 21). Between 1488 and $1515 \mathrm{~h}$, a building power failure occurred, but when the run was resumed - without pumping a solution containing $\mathrm{NH}_{4} \mathrm{NO}_{3}$ - the catalyst was quite stable (TOS between 1515 and $1762 \mathrm{~h}$ ), as shown in Figure 22. With addition of $40 \mathrm{ppmw} \mathrm{NH}_{4} \mathrm{NO}_{3}$ a second time (Figure 23), catalyst deactivation was again observed (TOS between 1762 and 1883 h). At this point, $\mathrm{NH}_{4} \mathrm{NO}_{3}$ addition was stopped (Figure 22), and the catalyst was found to be quite stable in the absence of the contaminant (TOS between 1883 and 1930

h). Finally, a third test with $\mathrm{NH}_{4} \mathrm{NO}_{3}$ addition was carried out between TOS of 1930 and $2161 \mathrm{~h}$, and measurable deactivation was observed (Figure 24).

During the first addition of 40 ppmw $\mathrm{NH}_{4} \mathrm{NO}_{3}$, the deactivation rate in terms of $\mathrm{X}_{\mathrm{CO}} / \mathrm{h}$ was higher, about 0.11 compared to 0.037 and 0.036 for the second and third periods of addition. 

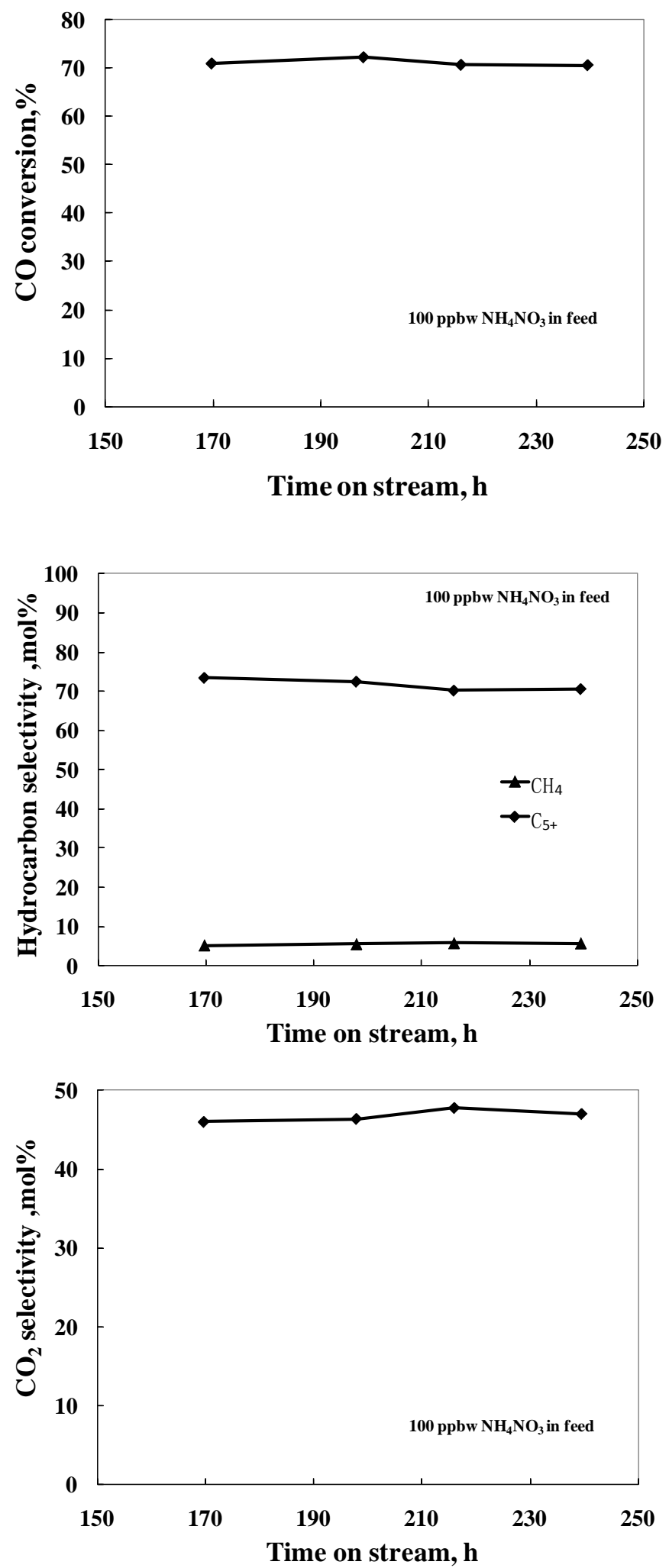

Figure 17 effect of 100 ppbw $\mathrm{NH}_{4} \mathrm{NO}_{3}$ on (top) $\mathrm{CO}$ conversion, (middle) $\mathrm{CH}_{4}$ and $\mathrm{C}_{5+}$ selectivities, and (bottom) $\mathrm{CO}_{2}$ selectivity $\left(270{ }^{\circ} \mathrm{C}, 175 \mathrm{psig}, \mathrm{H}_{2} / \mathrm{CO}=0.77,10 \mathrm{Nl} / \mathrm{g}\right.$-cat/h. 

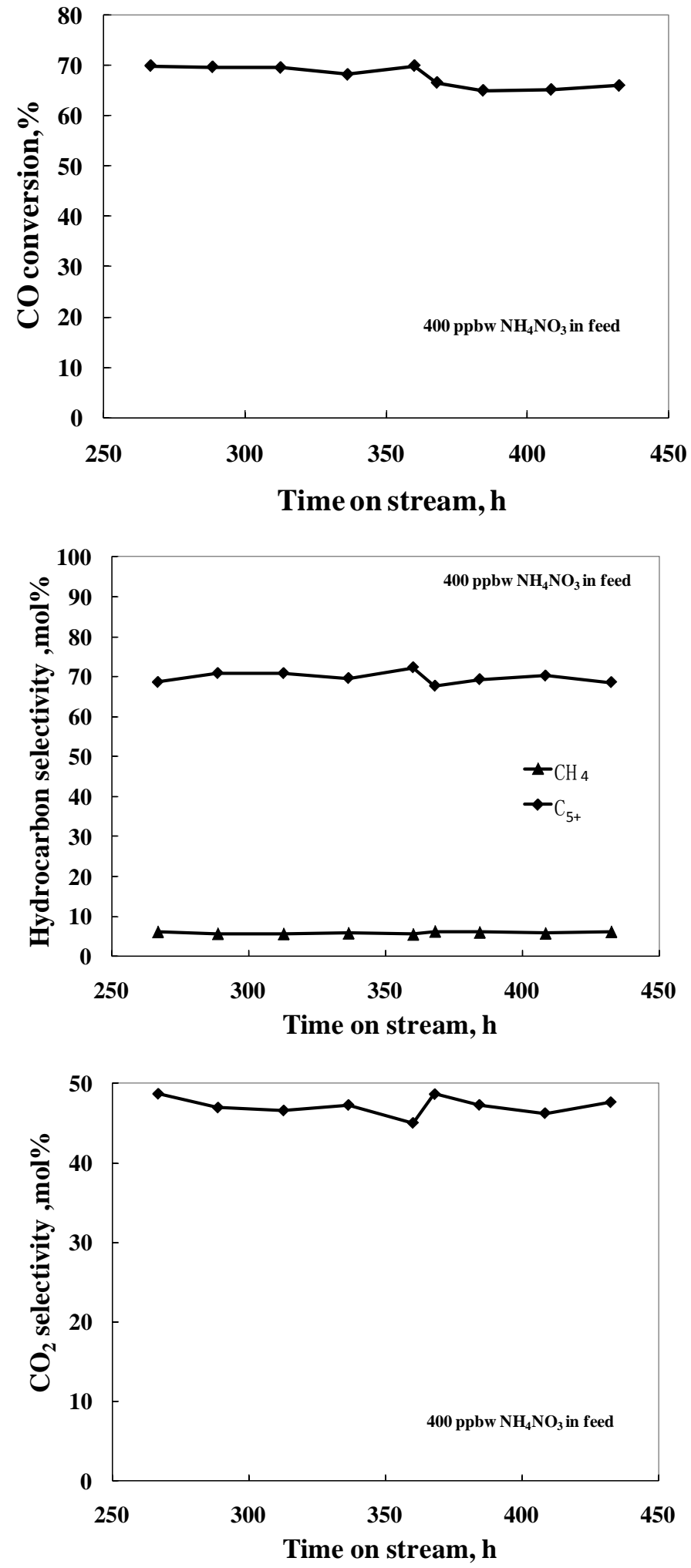

Figure 18 effect of 400 ppbw $\mathrm{NH}_{4} \mathrm{NO}_{3}$ on (top) $\mathrm{CO}$ conversion, (middle) $\mathrm{CH}_{4}$ and $\mathrm{C}_{5+}$ selectivities, and (bottom) $\mathrm{CO}_{2}$ selectivity $\left(270{ }^{\circ} \mathrm{C}, 175\right.$ psig, $\mathrm{H}_{2} / \mathrm{CO}=0.77,10 \mathrm{Nl} / \mathrm{g}$-cat/h.). 

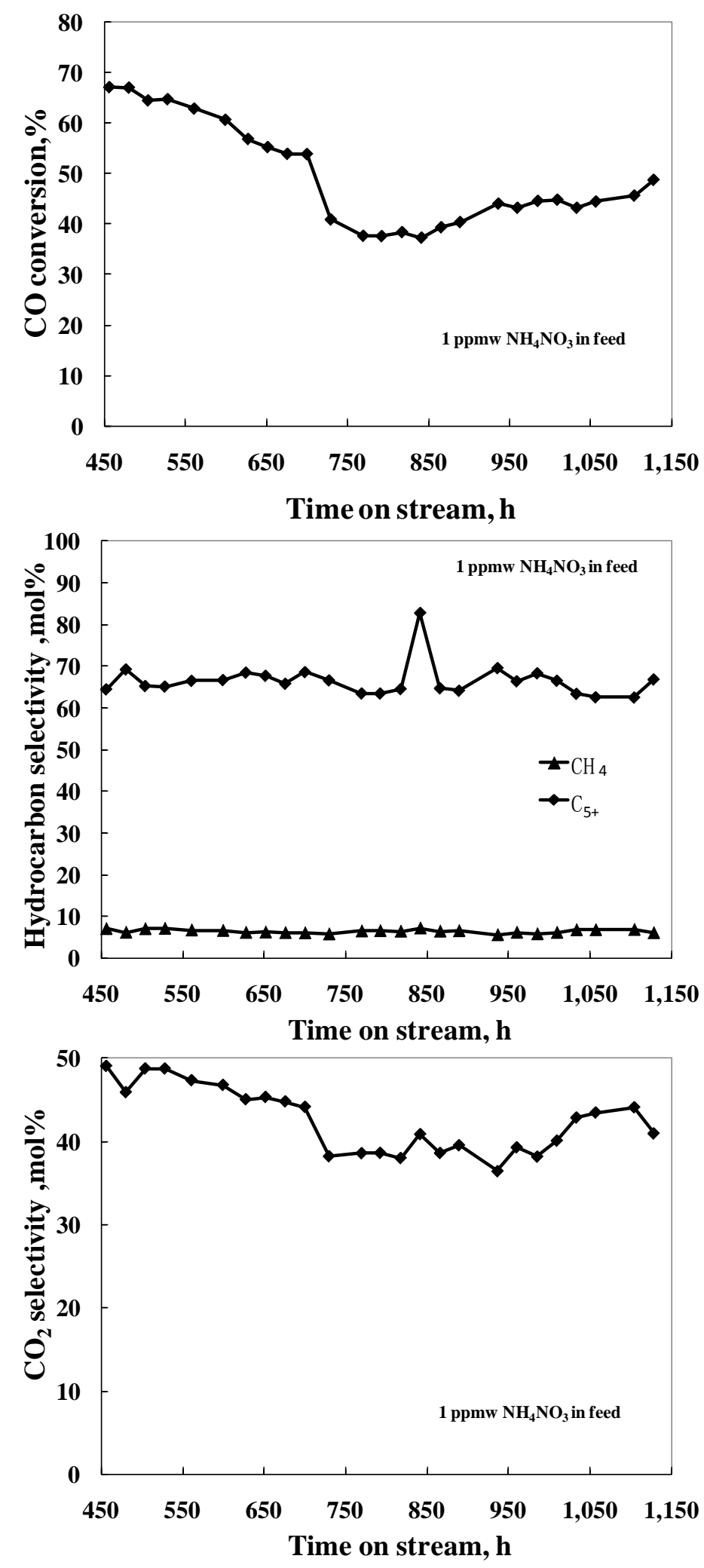

Figure 19 effect of 1 ppm $\mathrm{NH}_{4} \mathrm{NO}_{3}$ on (top) $\mathrm{CO}$ conversion, (middle) $\mathrm{CH}_{4}$ and $\mathrm{C}_{5+}$ selectivities, and (bottom) $\mathrm{CO}_{2}$ selectivity $\left(270{ }^{\circ} \mathrm{C}, 175 \mathrm{psig}, \mathrm{H}_{2} / \mathrm{CO}=0.77,10 \mathrm{Nl} / \mathrm{g}\right.$-cat/h.). 


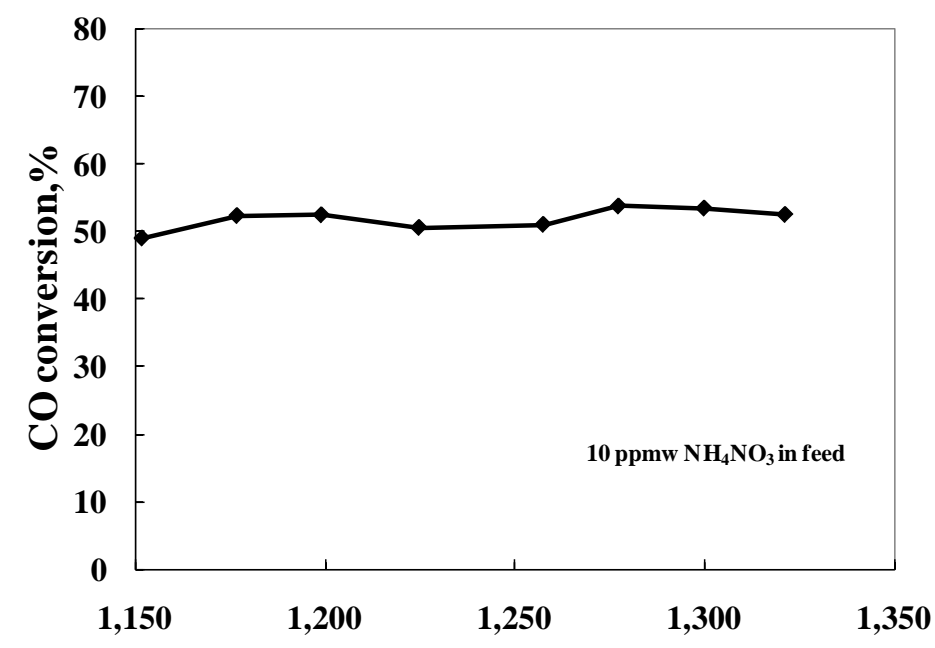

Time on stream, h

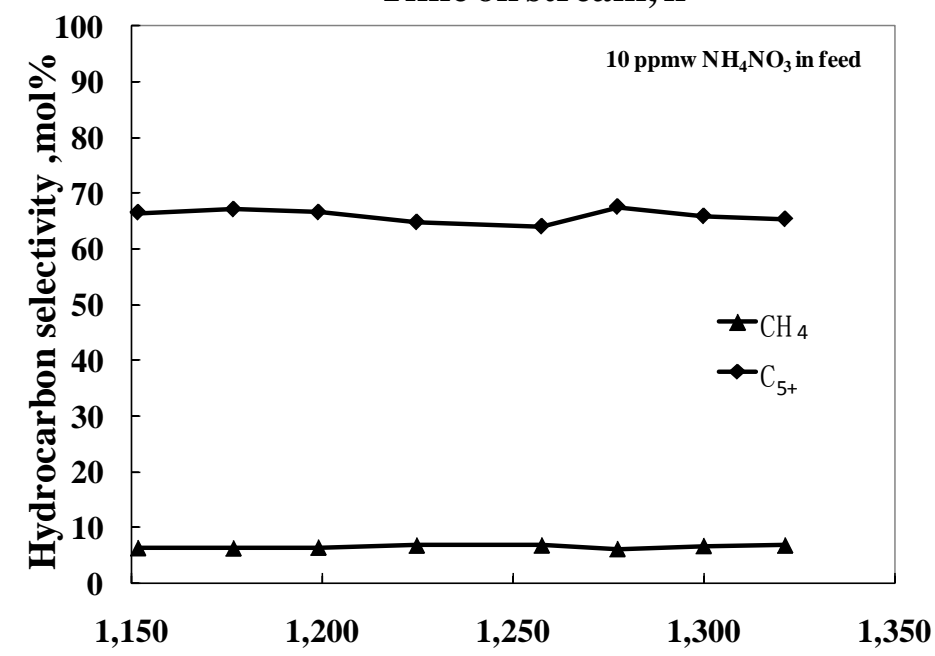

Time on stream, $h$

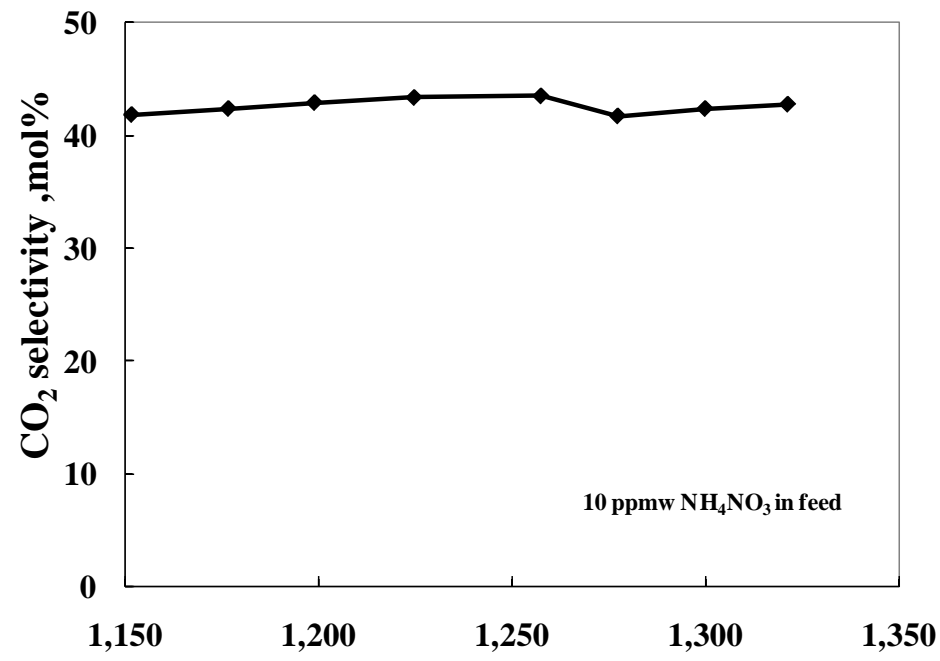

Time on stream, $h$

Figure 20 effect of 10 ppm $\mathrm{NH}_{4} \mathrm{NO}_{3}$ on (top) $\mathrm{CO}$ conversion, (middle) $\mathrm{CH}_{4}$ and $\mathrm{C}_{5+}$ selectivities, and (bottom) $\mathrm{CO}_{2}$ selectivity $\left(270{ }^{\circ} \mathrm{C}, 175 \mathrm{psig}, \mathrm{H}_{2} / \mathrm{CO}=0.77,10 \mathrm{Nl} / \mathrm{g}\right.$-cat/h.). 

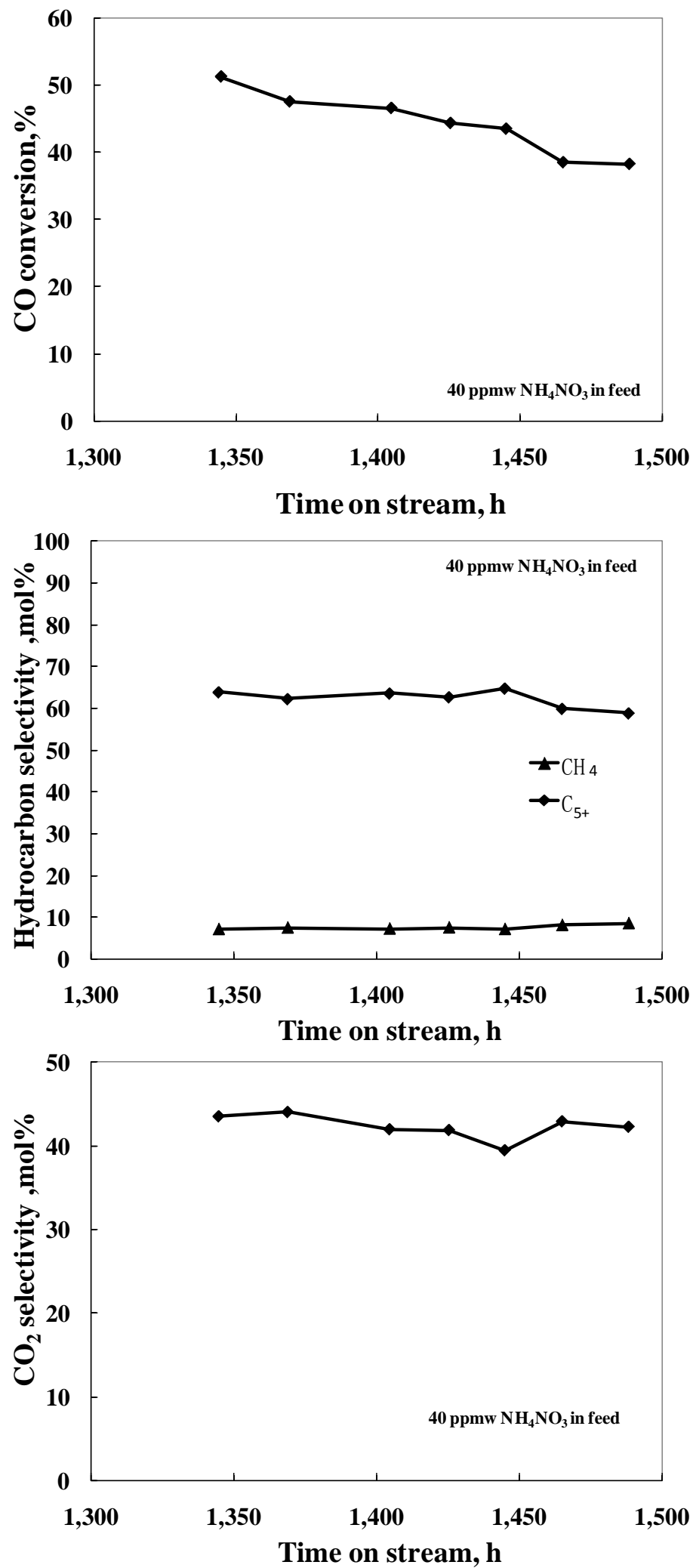

Figure 21 Effect of 40 ppm $\mathrm{NH}_{4} \mathrm{NO}_{3}$ on (top) $\mathrm{CO}$ conversion, (middle) $\mathrm{CH}_{4}$ and $\mathrm{C}_{5+}$ selectivities, and (bottom) $\mathrm{CO}_{2}$ selectivity (first addition) $\left(270{ }^{\circ} \mathrm{C}, 175 \mathrm{psig}, \mathrm{H}_{2} / \mathrm{CO}=0.77,10 \mathrm{Nl} / \mathrm{g}\right.$-cat/h.). 

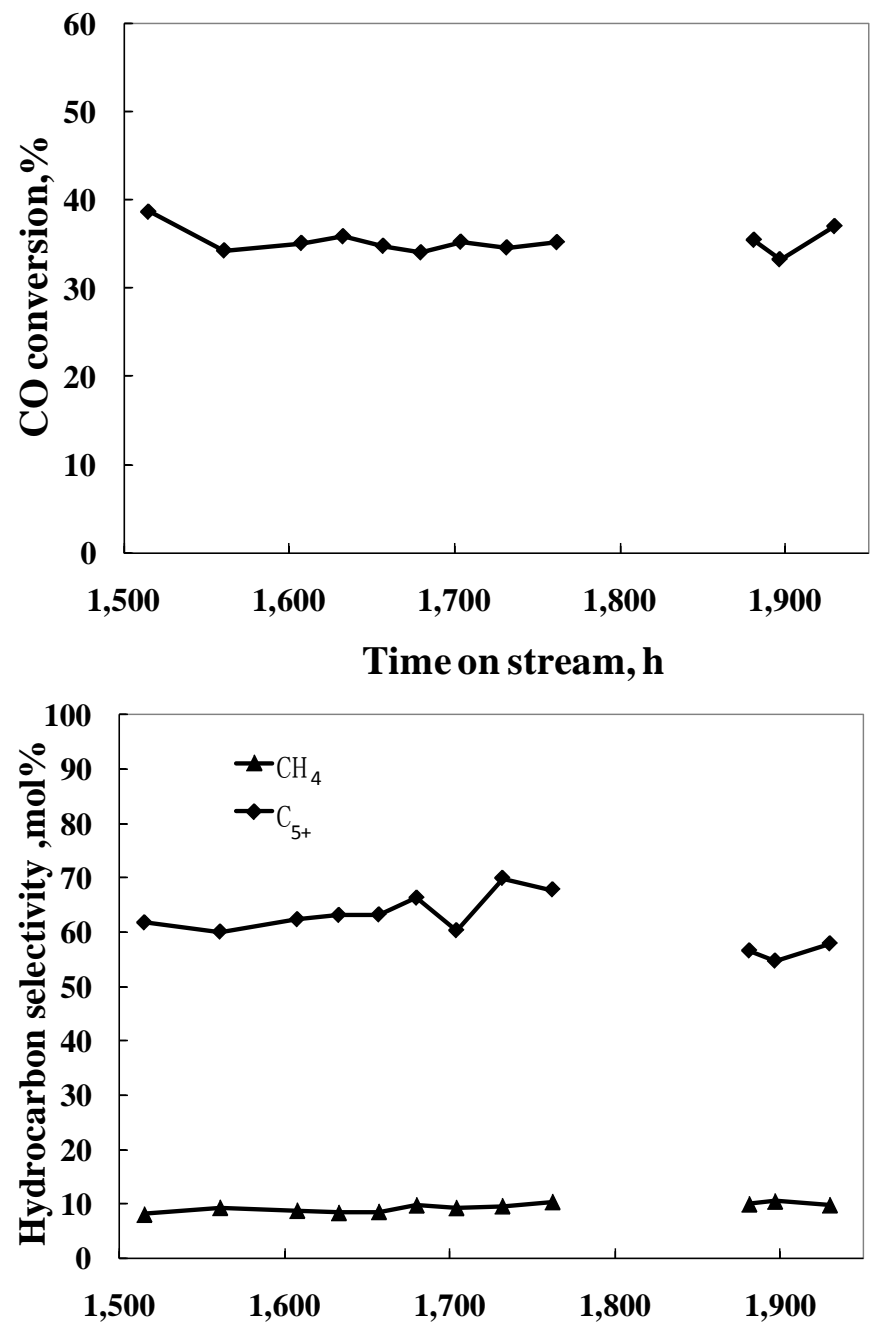

Time on stream, h

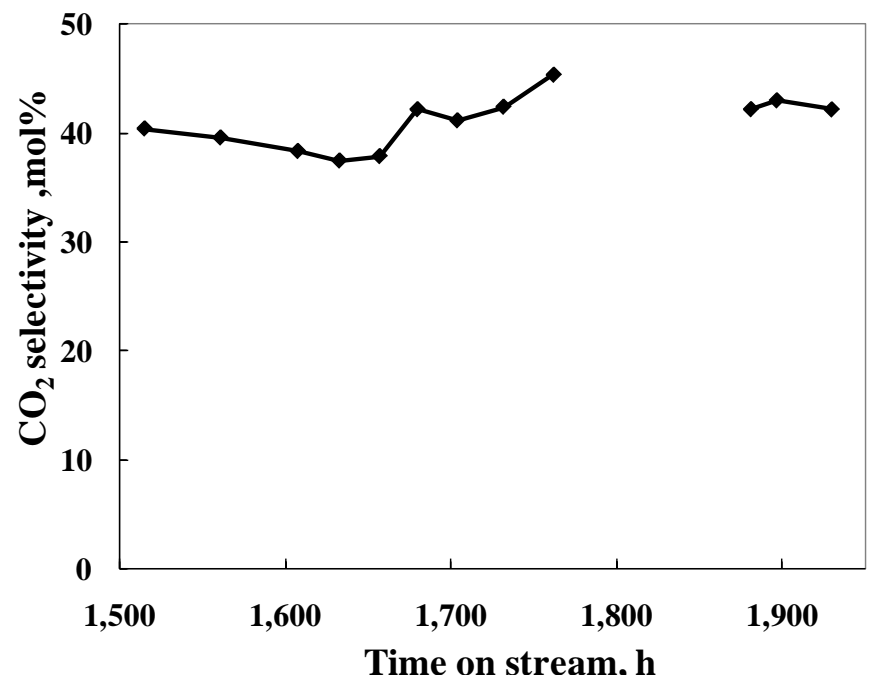

Figure 22 Stability test of resumed maw204 after power failure (top) $\mathrm{CO}$ conversion, (middle) $\mathrm{CH}_{4}$ and $\mathrm{C}_{5+}$ selectivities, and (bottom) $\mathrm{CO}_{2}$ selectivity $\left(270{ }^{\circ} \mathrm{C}, 175 \mathrm{psig}, \mathrm{H}_{2} / \mathrm{CO}=0.77,10 \mathrm{Nl} / \mathrm{g}\right.$-cat/h.). 


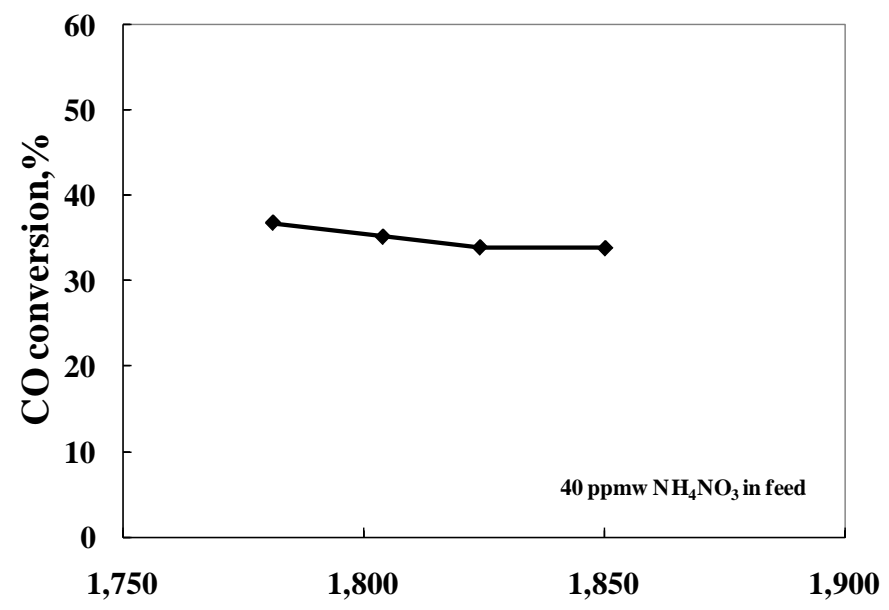

Time on stream, h
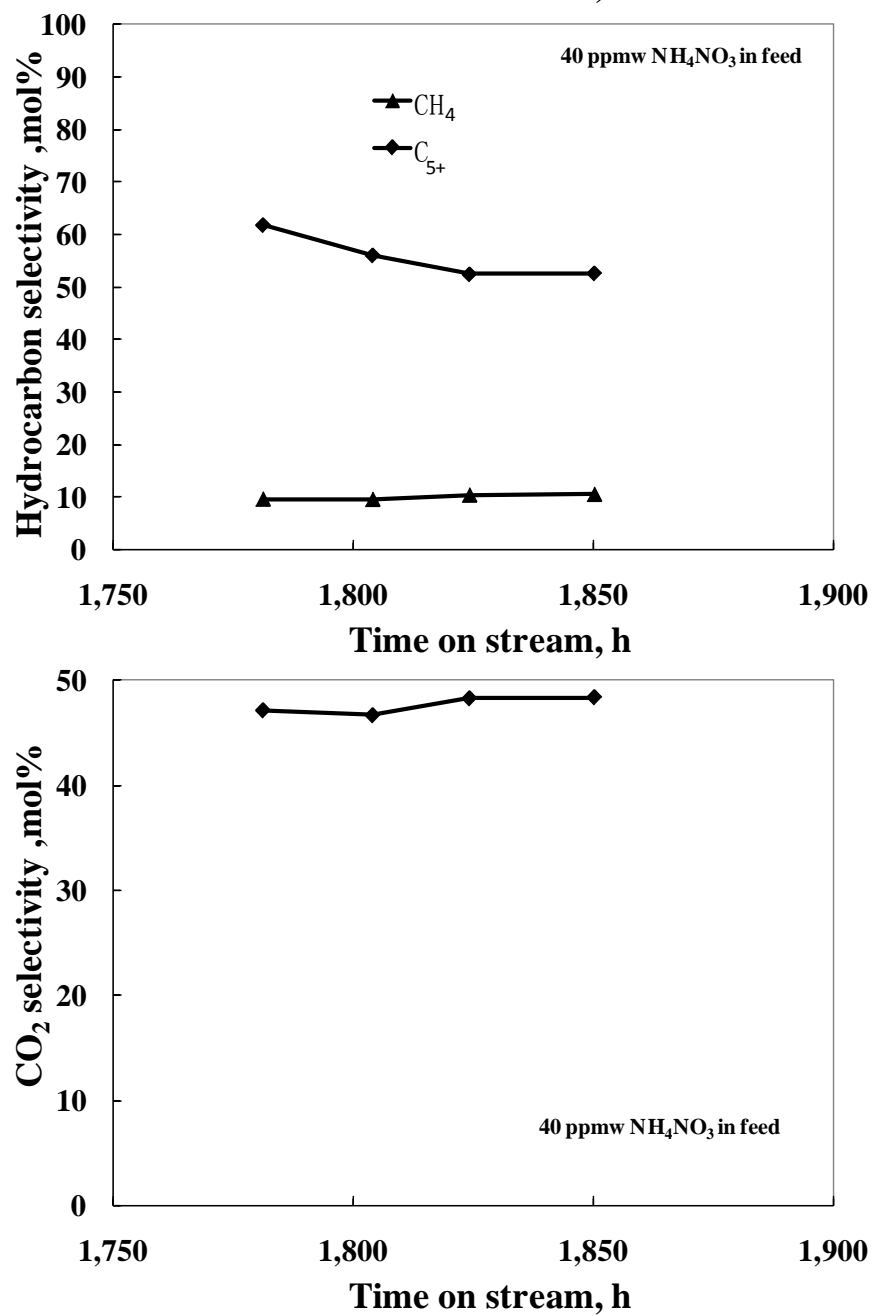

Figure 23 Effect of $40 \mathrm{ppm} \mathrm{NH}_{4} \mathrm{NO}_{3}$ on (top) $\mathrm{CO}$ conversion, (middle) $\mathrm{CH}_{4}$ and $\mathrm{C}_{5+}$ selectivities, and (bottom) $\mathrm{CO}_{2}$ selectivity ( $2^{\text {nd }}$ addition) $\left(270{ }^{\circ} \mathrm{C}, 175 \mathrm{psig}, \mathrm{H}_{2} / \mathrm{CO}=0.77,10 \mathrm{Nl} / \mathrm{g}\right.$-cat $/ \mathrm{h}$.). 

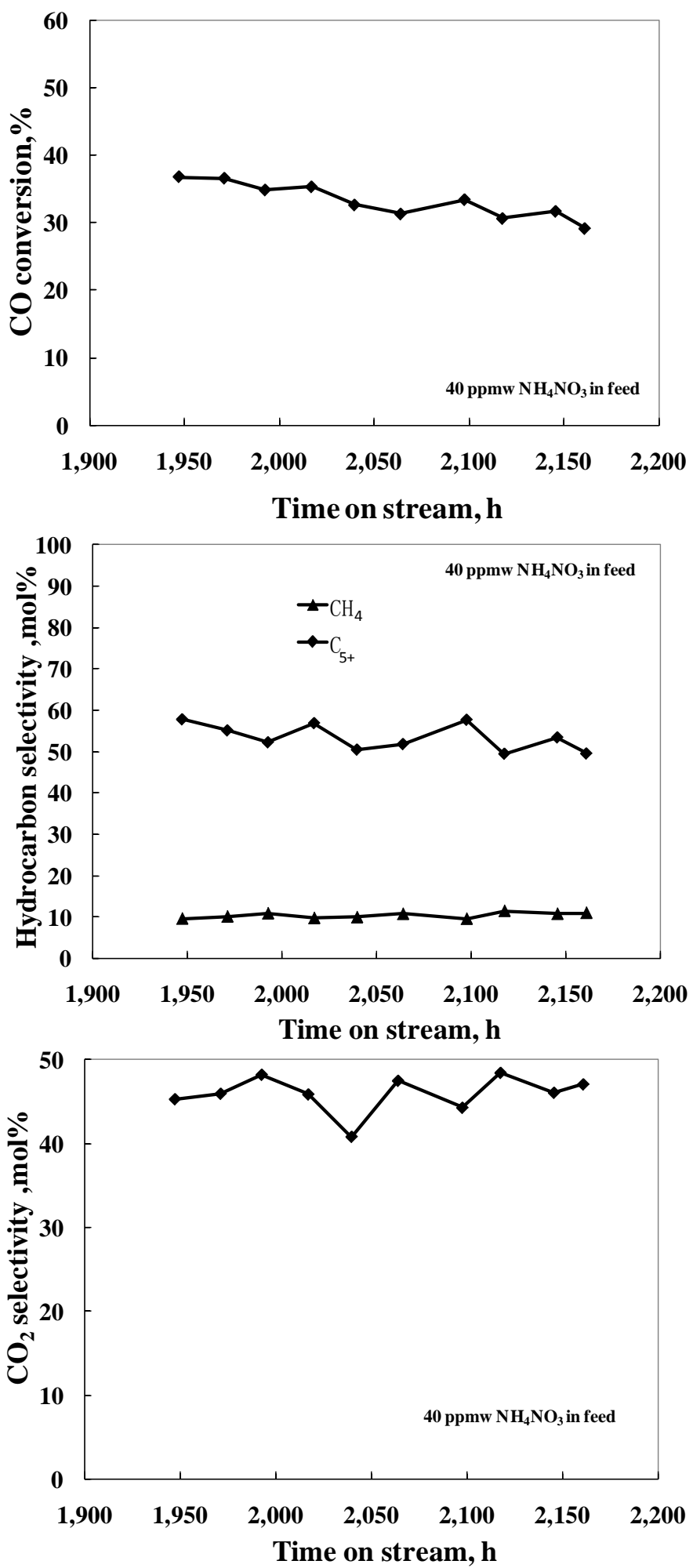

Figure 24 Effect of $40 \mathrm{ppm} \mathrm{NH}_{4} \mathrm{NO}_{3}$ on (top) $\mathrm{CO}$ conversion, (middle) $\mathrm{CH}_{4}$ and $\mathrm{C}_{5+}$ selectivities, and (bottom) $\mathrm{CO}_{2}$ selectivity ( $3^{\text {rd }}$ addition) $\left(270{ }^{\circ} \mathrm{C}, 175 \mathrm{psig}, \mathrm{H}_{2} / \mathrm{CO}=0.77,10 \mathrm{Nl} / \mathrm{g}\right.$-cat $/ \mathrm{h}$. $)$. 


\section{FT reaction: Sensitivity of a cobalt catalyst to co-fed gasification byproduct contaminants, including $\mathrm{KCl}, \mathrm{NaCl}, \mathrm{NaHCO}_{3}, \mathrm{KHCO}_{3}$, and $\mathrm{HCl}$}

\section{Sensitivity of a cobalt catalyst to alkali halides $-\mathrm{KCl}$ and $\mathrm{NaCl}$}

The sensitivity of the cobalt catalyst to alkali halide compounds was tested by subjecting the catalyst to FT feeds containing $\mathrm{KCl}$ and $\mathrm{NaCl}$. In a run lasting $2496 \mathrm{~h}$, the effect of $\mathrm{KCl}$ was extensively tested over the $0.5 \% \mathrm{Pt}-25 \% \mathrm{Co} / \gamma-\mathrm{Al}_{2} \mathrm{O}_{3}\left(150 \mathrm{~m}^{2} / \mathrm{g}\right.$ support $)$ catalyst. After achieving stability under clean conditions, poisoning was started with 100 ppbw $\mathrm{KCl}$ in the total feed, and then eight separate tests were conducted with increasing $\mathrm{KCl}$ concentrations. With the exception of the last test, all of the tests were conducted by adding $2 \mathrm{ml} / \mathrm{hr}$ of aqueous solutions to the syngas feed.

Tests were conducted at 100, 190, and 600 ppb, followed by 2, 20, 100, 500 and 860 ppm. Figures 25 and 26 illustrate three of the tests at lower concentrations. Testing periods varied from five to fourteen days, and since no poisoning effects were seen at all but the highest concentrations, there were generally no intervening baseline periods between the tests.

One of the exceptions to this was between tests with 100 ppm $\mathrm{KCl}$ and 500 ppm KCl levels. By this point ( 1750 hours on stream), CO conversion had fallen to $\sim 32 \%$, and so the space velocity was decreased to increase conversion. This was followed by a baseline period of six days before starting the next test. Due possibly to a combination of catalyst aging and cumulative poisoning effects, the baseline was not flat, and instead showed an average rate of decline of CO conversion of $\sim 0.4 \%$ per day. When $500 \mathrm{ppm} \mathrm{KCl}$ was added, this rate of decline increased to $~ 0.7 \%$ per day (Figure 27) showing some evidence of poisoning due to the $\mathrm{KCl}$.

A final test was conducted using the same aqueous solution, but doubling the aqueous solution feed rate to $4 \mathrm{ml} / \mathrm{hr}$, which increased the $\mathrm{KCl}$ concentration in the syngas to $860 \mathrm{ppmw}$. As seen in Figure 28, the CO conversion decreased rapidly and did not recover when the $\mathrm{KCl}$ feed was discontinued. 


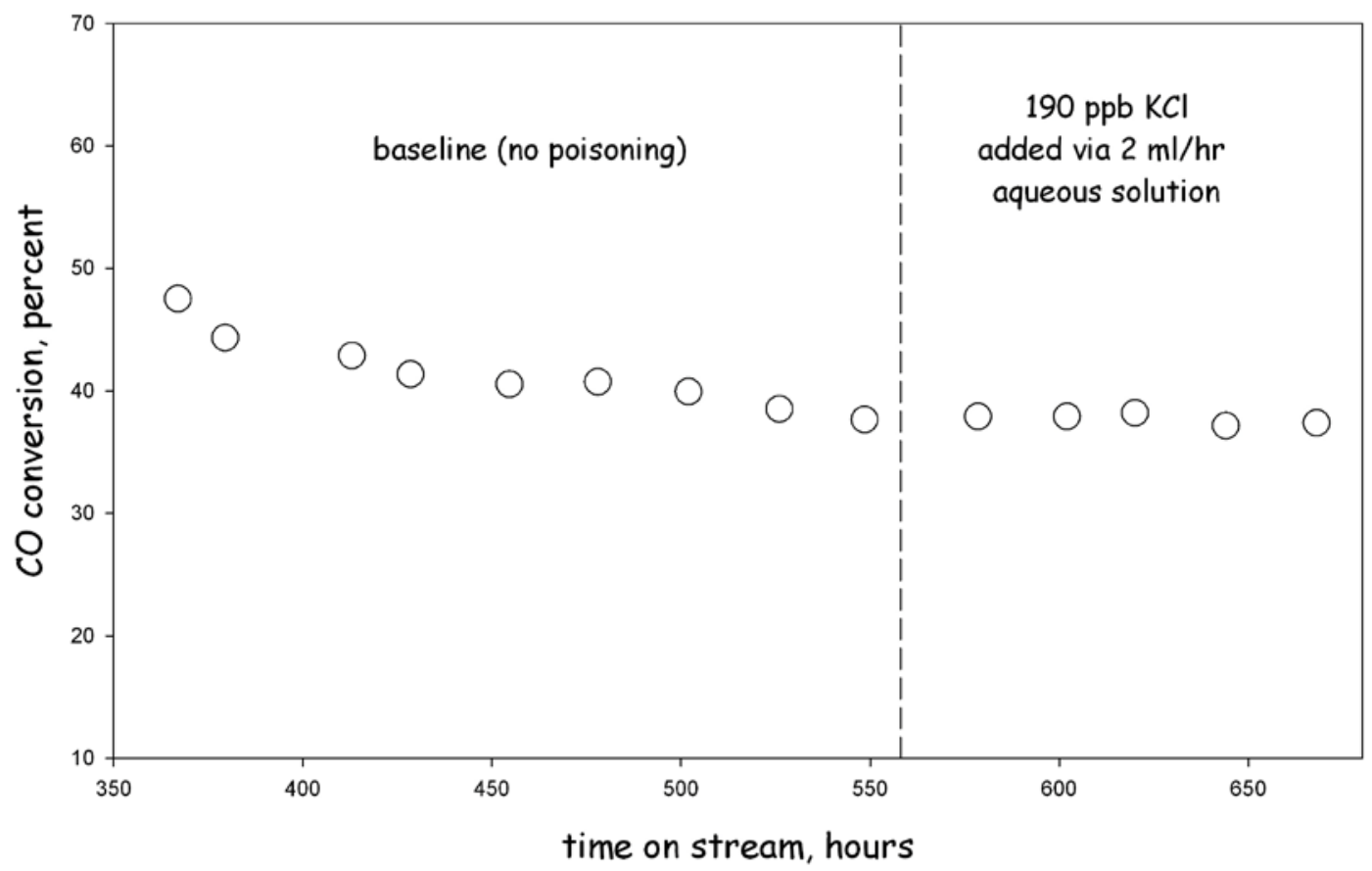

Figure 25: Effect of $\mathrm{KCl}(190 \mathrm{ppb})$ on CO conversion over $0.5 \% \mathrm{Pt}-25 \% \mathrm{Co} / \mathrm{Al}_{2} \mathrm{O}_{3}\left(150 \mathrm{~m}^{2} / \mathrm{g} \gamma-\mathrm{Al}_{2} \mathrm{O}_{3}\right.$ support) (GJ456). Conditions: $220^{\circ} \mathrm{C}, 280 \mathrm{psig}, \mathrm{H}_{2} / \mathrm{CO}=2.00, \mathrm{SV}=5 \mathrm{Sl} / \mathrm{g}$-cat/h. Run ID = AWP031. Reactor \#21. Charge: 8.6 g.

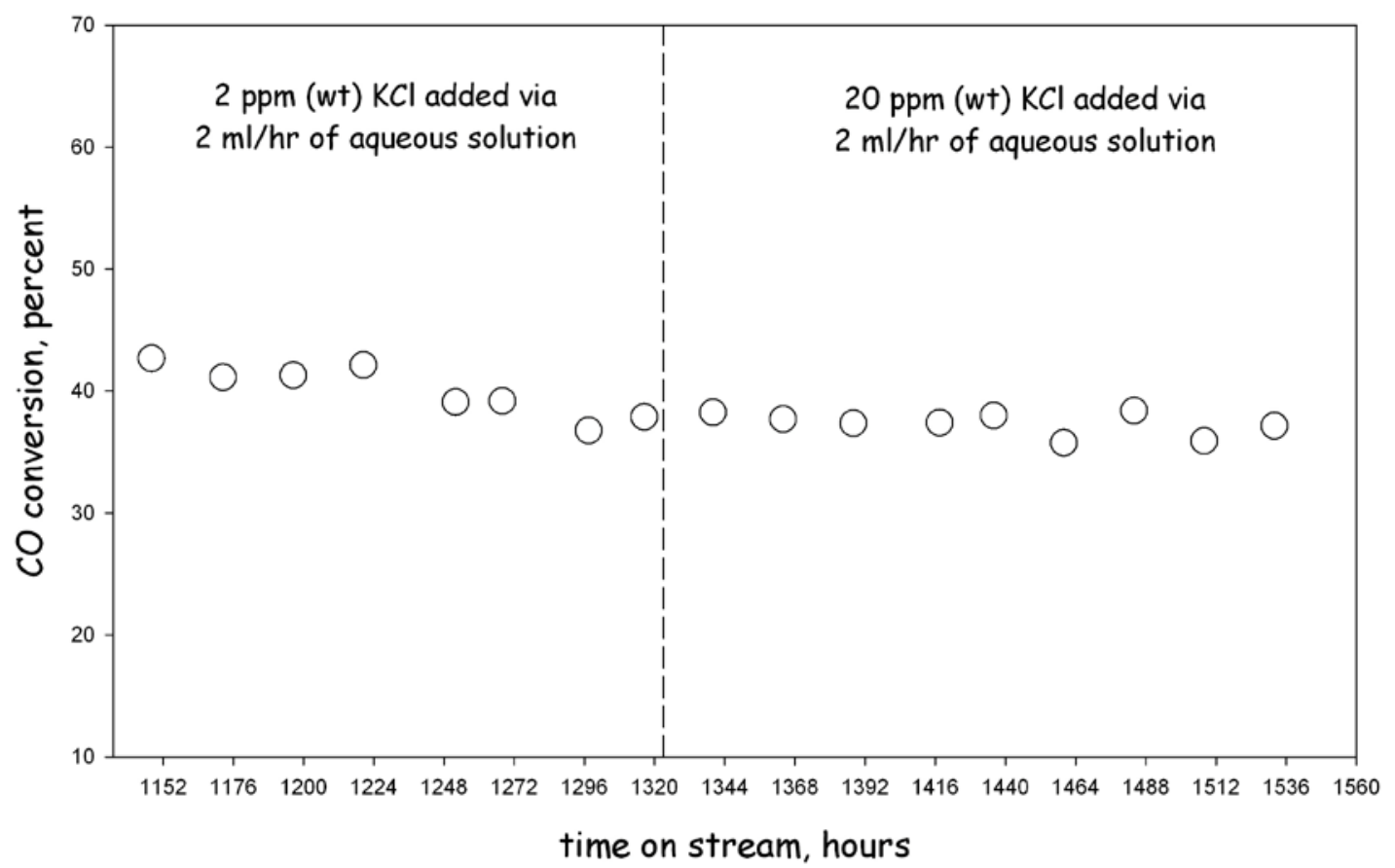

Figure 26: Effect of $\mathrm{KCl}(2 \mathrm{ppmw}$ and $20 \mathrm{ppmw})$ on CO conversion over $0.5 \% \mathrm{Pt}-25 \% \mathrm{Co} / \mathrm{Al}_{2} \mathrm{O}_{3}(150$ $\mathrm{m} 2 / \mathrm{g} \gamma-\mathrm{Al}_{2} \mathrm{O}_{3}$ support) (GJ456). Conditions: $220{ }^{\circ} \mathrm{C}, 280 \mathrm{psig}, \mathrm{H}_{2} / \mathrm{CO}=2.0, \mathrm{SV}=3.49 \mathrm{Sl} / \mathrm{g}_{\text {cat }} / \mathrm{h}$. Run ID = AWP031. Reactor \#21. Charge: $8.6 \mathrm{~g}$. 


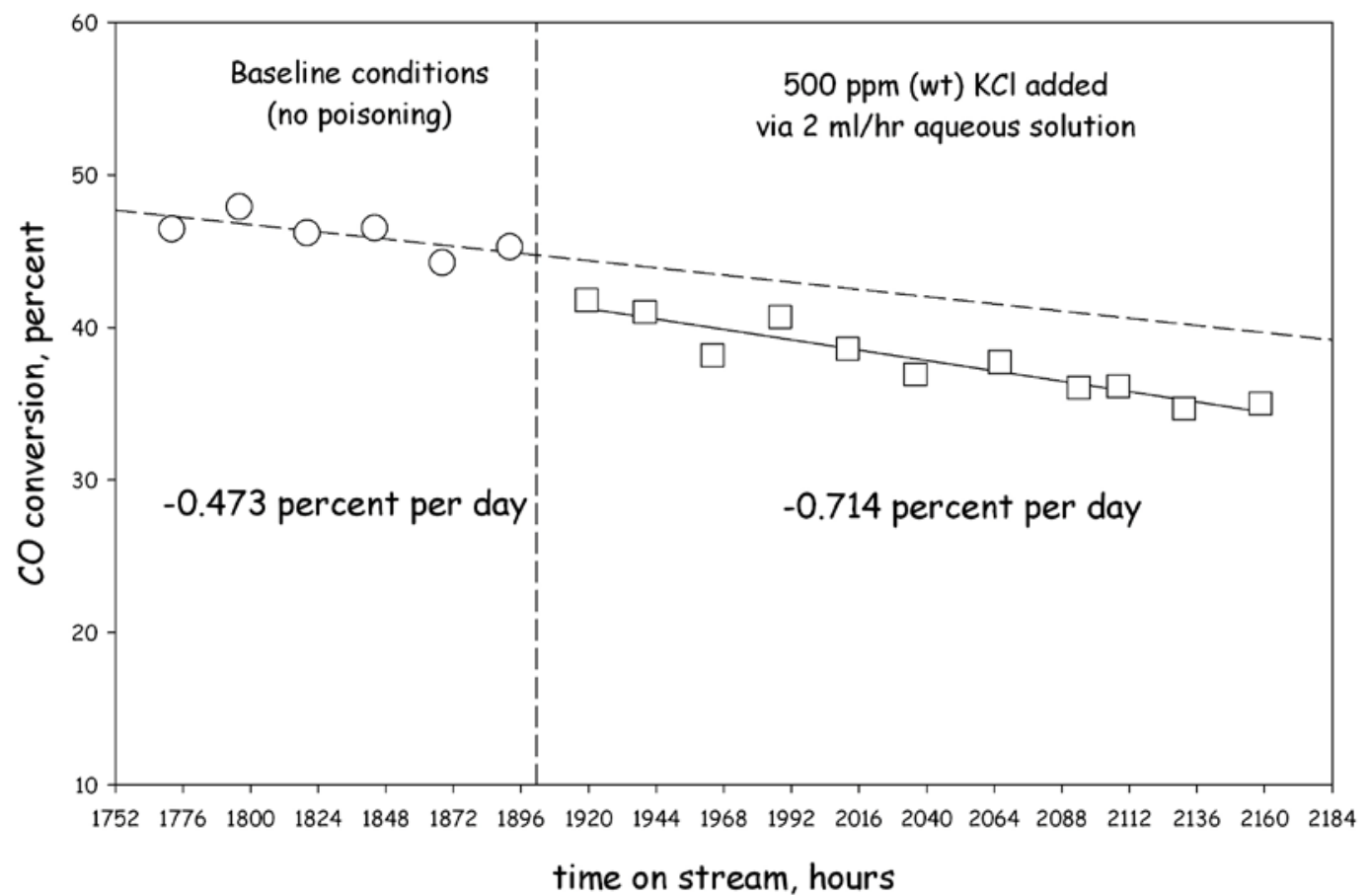

Figure 27: Effect of $\mathrm{KCl}(500 \mathrm{ppm})$ on CO conversion over $0.5 \% \mathrm{Pt}-25 \% \mathrm{Co} / \mathrm{Al}_{2} \mathrm{O}_{3}\left(150 \mathrm{~m}^{2} / \mathrm{g} \gamma-\mathrm{Al}_{2} \mathrm{O}_{3}\right.$ support) (GJ456). Conditions: $220{ }^{\circ} \mathrm{C}, 280$ psig, $\mathrm{H}_{2} / \mathrm{CO}=2.00, \mathrm{SV}=2.5 \mathrm{Sl} / \mathrm{g}$-cat/h. Run ID = AWP031. Reactor \#21. Charge: 8.6 g.

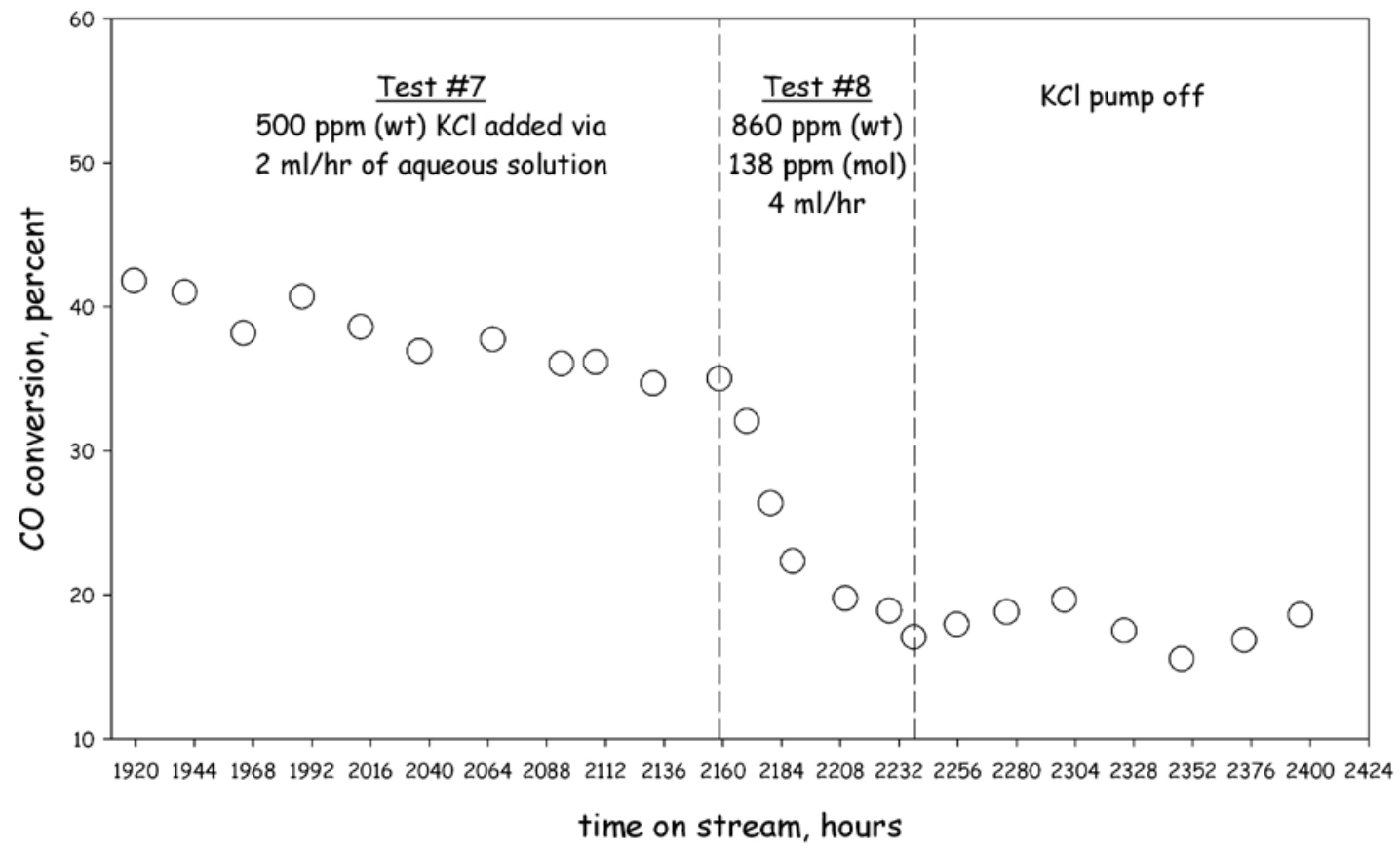

Figure 28: Effect of $\mathrm{KCl}(500 \mathrm{ppm}$ and $860 \mathrm{ppm})$ on CO conversion over $0.5 \% \mathrm{Pt}-25 \% \mathrm{Co} / \mathrm{Al}_{2} \mathrm{O}_{3}(150$ $\mathrm{m}^{2} / \mathrm{g} \gamma-\mathrm{Al}_{2} \mathrm{O}_{3}$ support) (GJ456). Conditions: $220{ }^{\circ} \mathrm{C}, 280 \mathrm{psig}, \mathrm{H}_{2} / \mathrm{CO}=2.003, \mathrm{SV}=2.50 \mathrm{Sl} / \mathrm{g}$-cat $/ \mathrm{h}$. Run ID = AWP031. Reactor \#21. Charge: $8.6 \mathrm{~g}$. 
In another test, $\mathrm{NaCl}$ poisoning studies were carried out over a $1394 \mathrm{~h}$ period, whereby four separate tests were conducted by increasing the amounts of $\mathrm{NaCl}$. Typically, runs are started with a space velocity of 8-10 standard liters of syngas per hour per gram of catalyst (slph/g). Initial CO conversions of $60-70 \%$ are seen, but this drops off rapidly, typically to $25 \%$ in the first $24-48$ hours. The SV is then reduced once or twice over the course of the next few days until a stable conversion of about $40-50 \%$ is achieved, usually with a SV of 3-5 slph/g. But for this run, the conversion stabilized at a SV of $7.5 \mathrm{slph} / \mathrm{g}$ and the first three tests were all conducted at this feed rate. The $\mathrm{NaCl}$ was added by injecting $2 \mathrm{ml} / \mathrm{hr}$ of an aqueous solution. After the first test at 100 ppbw showed no loss of conversion, the $\mathrm{NaCl}$ concentration of this aqueous solution was increased to raise concentration in the total feed tenfold to 1 ppm. As shown in Figure 29, the CO conversion was unaffected.

When this second test also showed no loss of activity, the strength of the $\mathrm{NaCl}$ solution was again increased, raising the $\mathrm{NaCl}$ concentration in the total feed to $50 \mathrm{ppm}$. For the first five days there was no loss of activity, but then the conversion dropped precipitously (Figure 30) and showed no evidence of recovering after the $\mathrm{NaCl}$ feed was discontinued. Though there was no evidence to either prove or disprove it, the assumption was that some interruption of reactor conditions had occurred late that fifth evening that damaged the catalyst.

The space velocity was decreased from $7.5 \mathrm{slph} / \mathrm{g}$ to $2.5 \mathrm{slph} / \mathrm{g}$ to regain conversion. After a baseline was established, a fourth test was started. Using the same $\mathrm{NaCl}$ solution with the decreased SV, injecting $2 \mathrm{ml} / \mathrm{hr}$ yielded a $\mathrm{NaCl}$ concentration in the total feed of $134 \mathrm{ppmw}$.

The conversion dropped by $~ 10 \%$ in the first two days, but then remained nearly constant for four more days (Figure 31) before another 10\% drop overnight, followed by a partial recovery. Again, there was no evidence to indicate any change in reactor conditions during the evening. We can only surmise that an interruption in conditions occurred during the run, but that this situation had self corrected by the time the product gas was sampled the following morning. 


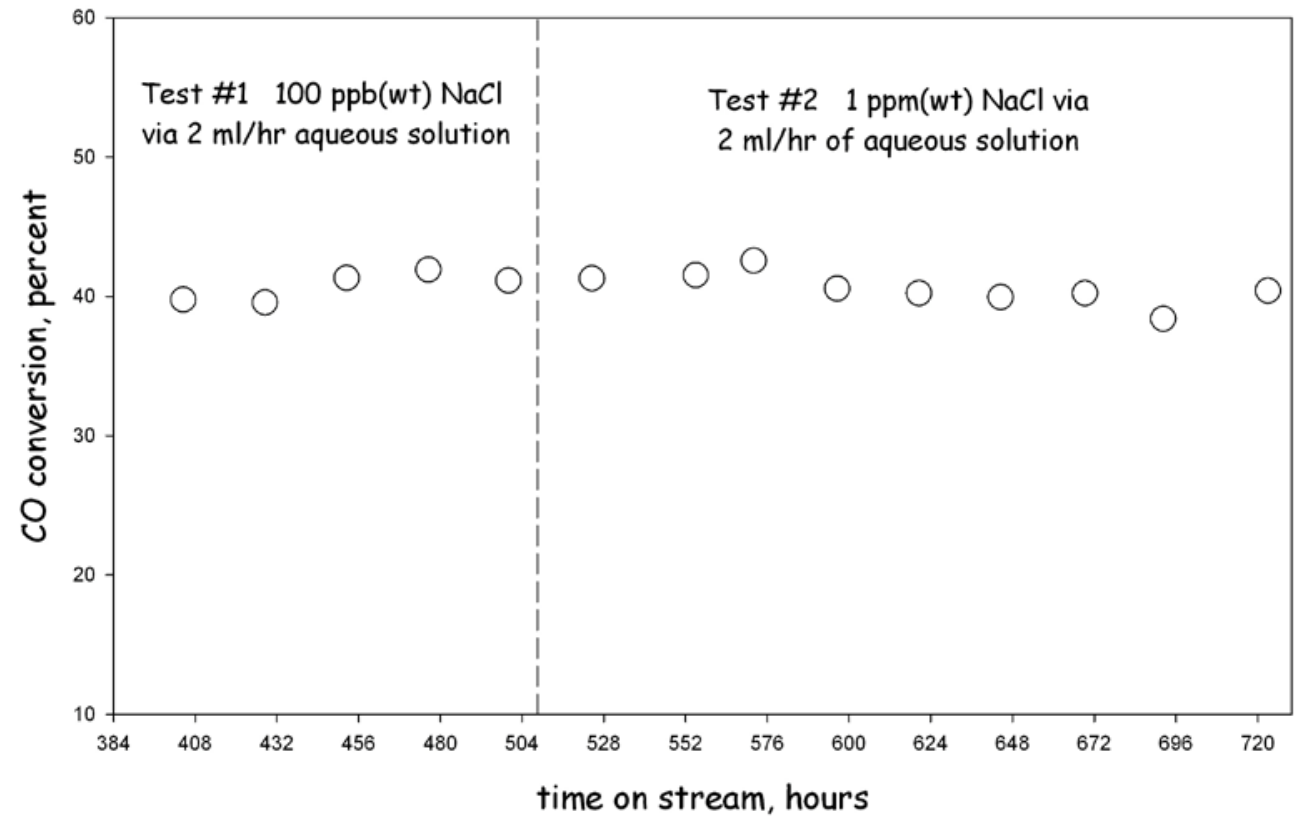

Figure 29: Effect of $\mathrm{NaCl}(100 \mathrm{ppbw}$ and $1 \mathrm{ppmw})$ on $\mathrm{CO}$ conversion over $0.5 \% \mathrm{Pt}-25 \% \mathrm{Co} / \mathrm{Al}_{2} \mathrm{O}_{3}(150$ $\mathrm{m}^{2} / \mathrm{g} \gamma-\mathrm{Al}_{2} \mathrm{O}_{3}$ support) (GJ456). Conditions: $220{ }^{\circ} \mathrm{C}, 280 \mathrm{psig}, \mathrm{H}_{2} / \mathrm{CO}=2.02, \mathrm{SV}=7.52 \mathrm{Sl} / \mathrm{g}-\mathrm{cat} / \mathrm{h}$. Run ID = AWP036. Reactor \#23. Charge: $8.6 \mathrm{~g}$.

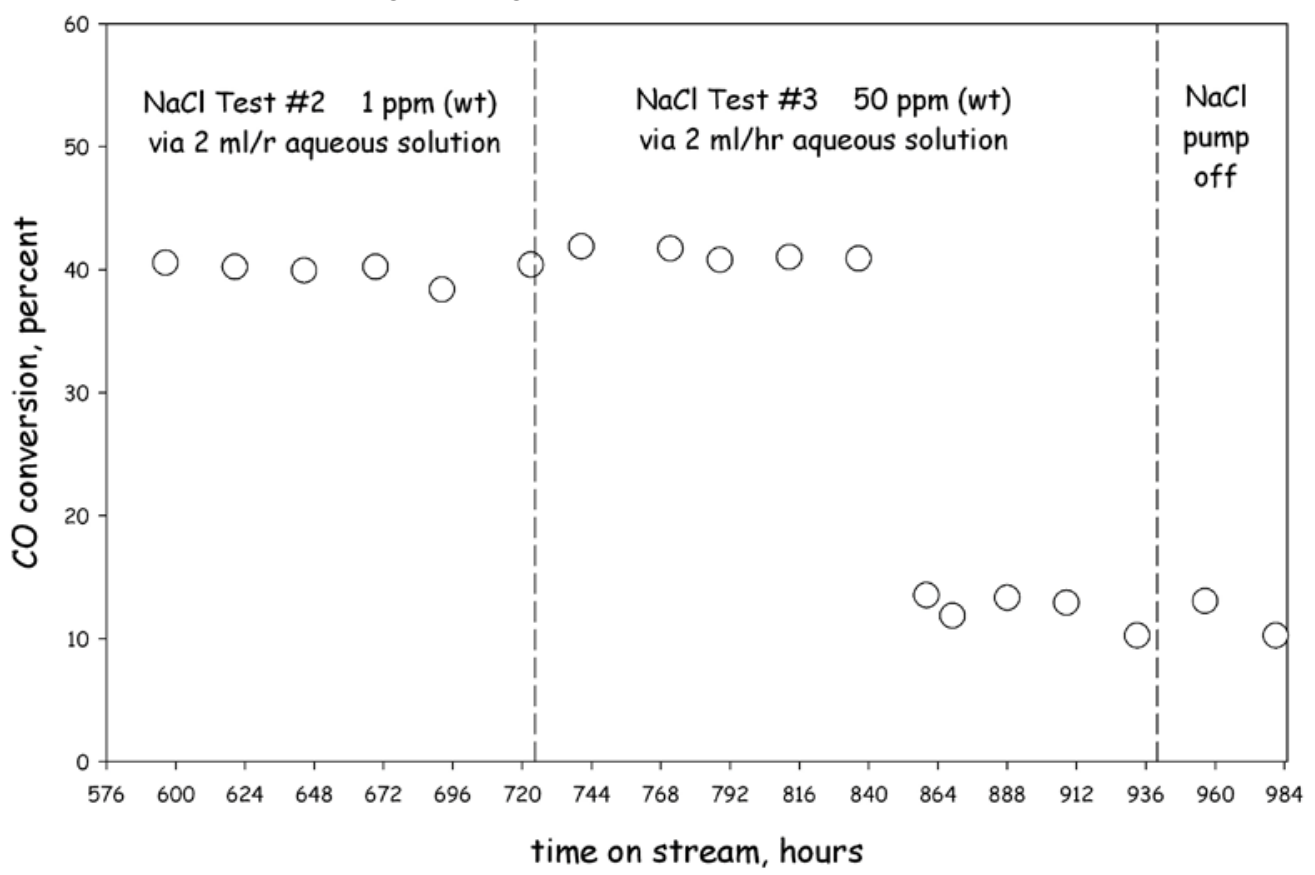

Figure 30: Effect of $\mathrm{NaCl}(1 \mathrm{ppbw}$ and $50 \mathrm{ppmw})$ on CO conversion over $0.5 \% \mathrm{Pt}-25 \% \mathrm{Co} / \mathrm{Al}_{2} \mathrm{O}_{3}(150$ $\mathrm{m}^{2} / \mathrm{g} \gamma-\mathrm{Al}_{2} \mathrm{O}_{3}$ support) (GJ456). Conditions: $220{ }^{\circ} \mathrm{C}, 280 \mathrm{psig}, \mathrm{H}_{2} / \mathrm{CO}=2.02, \mathrm{SV}=7.52 \mathrm{Sl} / \mathrm{g}$-cat/h. Run ID = AWP036. Reactor \#23. Charge: $8.6 \mathrm{~g}$. 


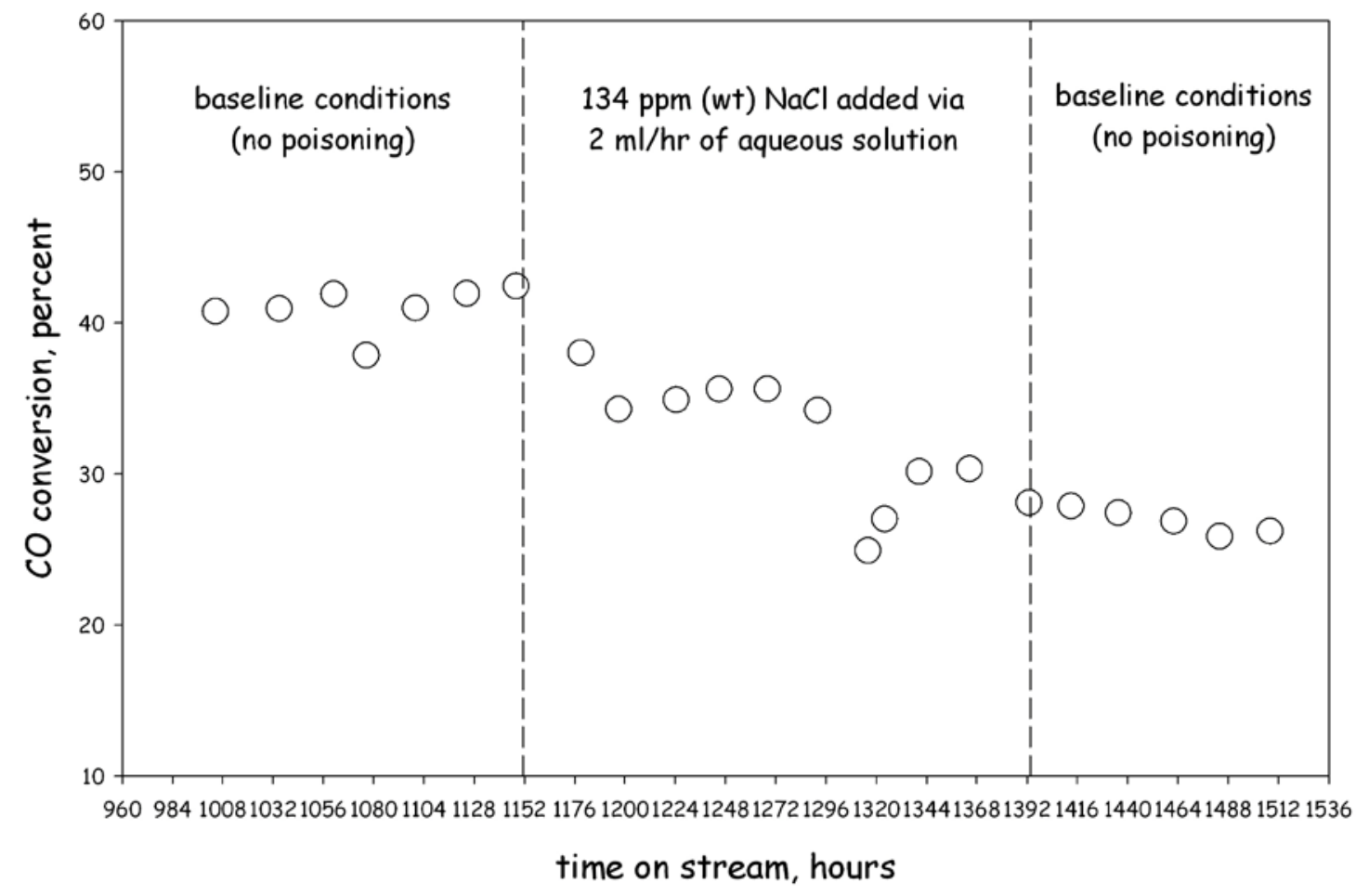

Figure 31: Effect of $\mathrm{NaCl}$ (134 ppmw) on CO conversion over $0.5 \% \mathrm{Pt}-25 \% \mathrm{Co} / \mathrm{Al}_{2} \mathrm{O}_{3}\left(150 \mathrm{~m}^{2} / \mathrm{g}-\mathrm{Al}_{2} \mathrm{O}_{3}\right.$ support) (GJ456). Conditions: $220{ }^{\circ} \mathrm{C}, 280 \mathrm{psig}, \mathrm{H}_{2} / \mathrm{CO}=2.02, \mathrm{SV}=2.519 \mathrm{Sl} / \mathrm{g}$-cat $/ \mathrm{h}$. Run ID = AWP036. Reactor \#23. Charge: $8.6 \mathrm{~g}$. 


\section{Decoupling the poisoning impact of alkali and halide - sensitivity of a cobalt-based FT catalyst to co-fed $\mathrm{KHCO}_{3}, \mathrm{NaHCO}_{3}$, and $\mathrm{HCl}$}

Starting with $100 \mathrm{ppb}(\mathrm{wt})$ in the total syngas feed, the $\mathrm{KHCO}_{3}$ concentration was increased to 1 ppm, 10 ppm, 100 ppm and finally 1000 ppm. All were performed by the injection of $1 \mathrm{ml} / \mathrm{hr}$ of aqueous $\mathrm{KHCO}_{3}$ solutions of increasing concentrations, and none of them showed any discernible loss of conversion that could be attributed to the $\mathrm{KHCO}_{3}$ addition. Figures 32 and 33 illustrate the $\mathrm{CO}$ conversion of four of these five tests.

After no poisoning could be demonstrated with $\mathrm{KHCO}_{3}$, a sixth poisoning test was conducted, switching to a $\mathrm{NaHCO}_{3}$ solution to achieve 138 ppbw $\mathrm{NaHCO}_{3}$. With no apparent loss of conversion after six days (Figure 34), a new test was started, increasing the $\mathrm{NaHCO}_{3}$ concentration to $138 \mathrm{ppmw}$ (Figure 34). Again, no significant deactivation was observed and after the second $\mathrm{NaHCO}_{3}$ test was completed, the reactor was returned to baseline conditions. The MFC failed after five days and the run was shut down.

Another run was_intended to test various levels of $\mathrm{NaHCO}_{3}$; however, the first test (at $100 \mathrm{ppb}$ $\mathrm{NaHCO}_{3}$ ) showed an unexpected drop in conversion (Figure 35) and the reactor was returned to baseline conditions to regain steady conversion. The $100 \mathrm{ppb}(\mathrm{wt})$ test was then repeated with a fresh $\mathrm{NaHCO}_{3}$ solution, this time with no loss of conversion. To confirm that the $\mathrm{NaHCO}_{3}$ solution used for the first test had not been contaminated in some way, it was retested at the end of the $\mathrm{KHCO}_{3}$ poisoning run, as described in the previous paragraph. Due to small differences in both the amount of catalyst charge in the reactor and the syngas feed rate, this repeated test was actually at a concentration of 138 ppbw.

Since the second $\mathrm{NaHCO}_{3}$ test in the other reactor - i.e., the one at 138 ppmw - had just demonstrated no loss in activity at a concentration that was 1000x greater than the 138 ppbw test, a final test was made using a $\mathrm{NaHCO}_{3}$ concentration in the total feed of $1000 \mathrm{ppmw}$. It too showed no measurable loss in conversion, as shown in Figure 36. 
Following the termination of the run that had a problem with the CO MFC, the reactor was cleaned and prepared for another run. The CO MFC was tested and showed no sign of its previous problem. The assumption was that the problem had perhaps been due to moisture in the MFC's sensor loop, and that the sensor had subsequently dried out, as the MFC was again functioning normally.

To test various levels of $\mathrm{HCl}$ contamination, $1 \mathrm{ml} / \mathrm{hr}$ of an aqueous $\mathrm{HCl}$ solution was first used to provide a concentration of $100 \mathrm{ppbw} \mathrm{HCl}$ in the total syngas feed. When no loss of conversion was seen, the concentration of the $\mathrm{HCl}$ solution was increased 100 fold, increasing the $\mathrm{HCl}$ concentration in the feed to $10 \mathrm{ppmw}$. Figure 37 illustrates the conversion at both the $100 \mathrm{ppb}$ and $10 \mathrm{ppm}$ concentrations.

With some loss of activity apparent at $10 \mathrm{ppm}$, the $\mathrm{HCl}$ feed was discontinued for several more days to ensure that the loss of conversion was permanent. After a steady baseline at a reduced conversion was demonstrated, a test at $50 \mathrm{ppmw} \mathrm{HCl}$ was started, but the run was terminated following a loss in all electrical power to the CAER laboratory. 
R21 AWPO42 3rd KHCO3 test

$7.8 \mathrm{~g}$ GJ 456 (25\% Co, 0.5\% Pt, $150 \mathrm{~m}^{2} / \mathrm{g}$ alumina)

$\mathrm{SV}=1.50 \mathrm{slph} / \mathrm{g}(\mathrm{H} 2 / \mathrm{CO}=2.01), \quad 220 \mathrm{C}, 280 \mathrm{psig}$

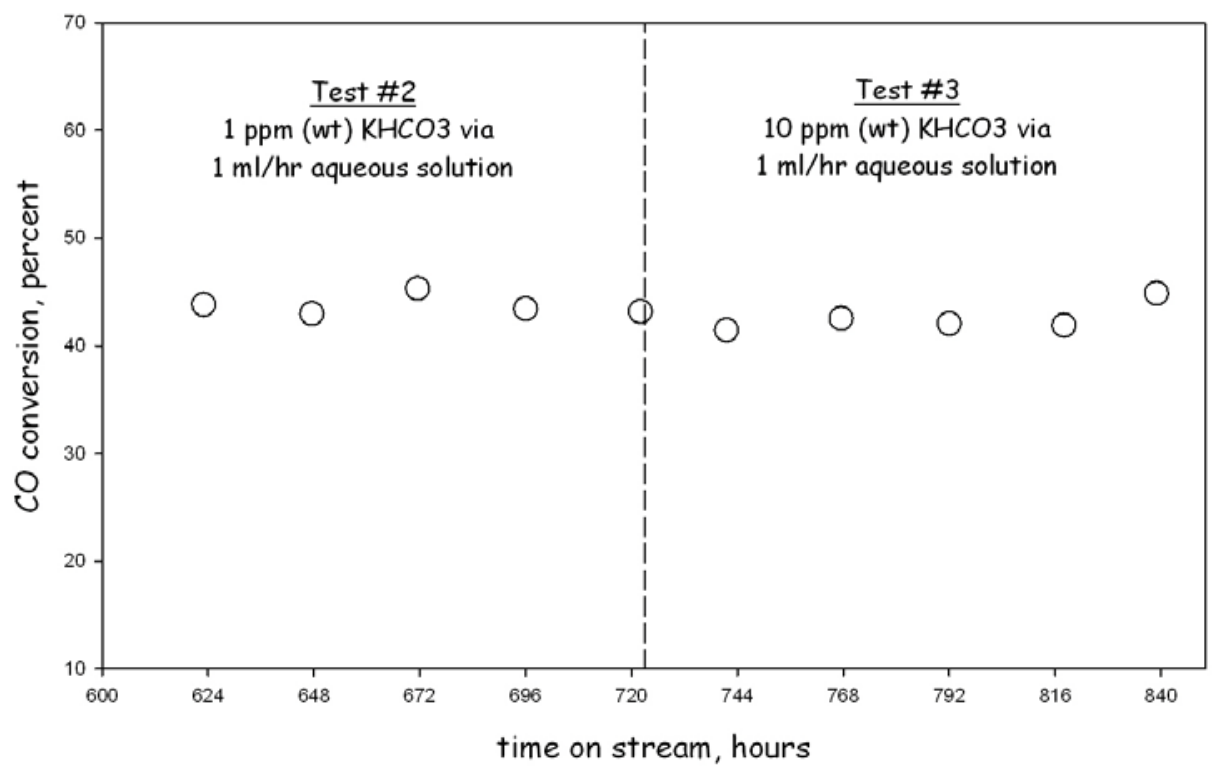

Figure 32

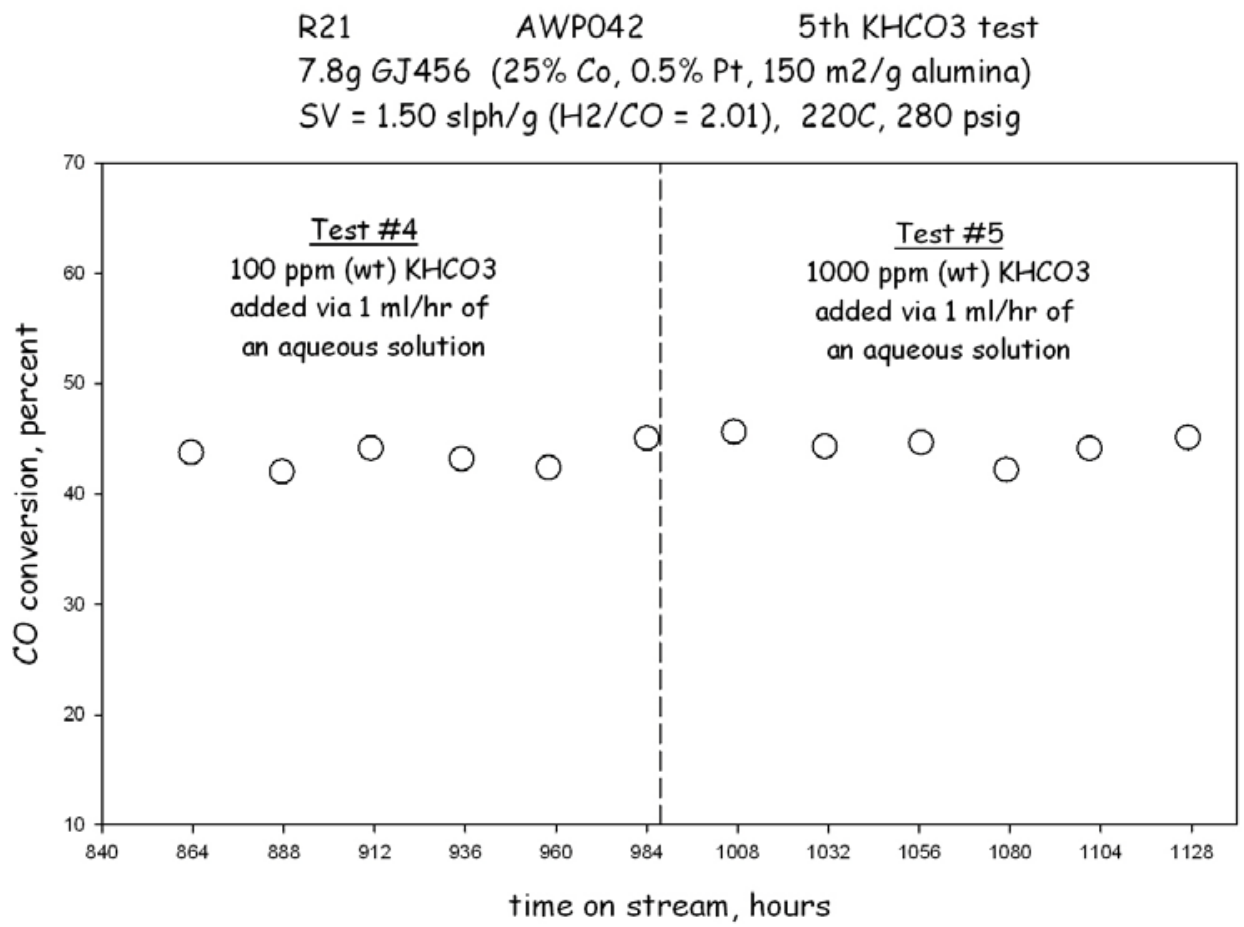

Figure 33 
R21

AWP042

$\mathrm{NaHCO} 3$ test

$7.8 \mathrm{~g}$ GJ 456 ( $25 \%$ Co, 0.5\% Pt, $150 \mathrm{~m} 2 / \mathrm{g}$ alumina)

$\mathrm{SV}=1.50 \mathrm{slph} / \mathrm{g}(\mathrm{H} 2 / \mathrm{CO}=2.01), 220 \mathrm{C}, 280 \mathrm{psig}$

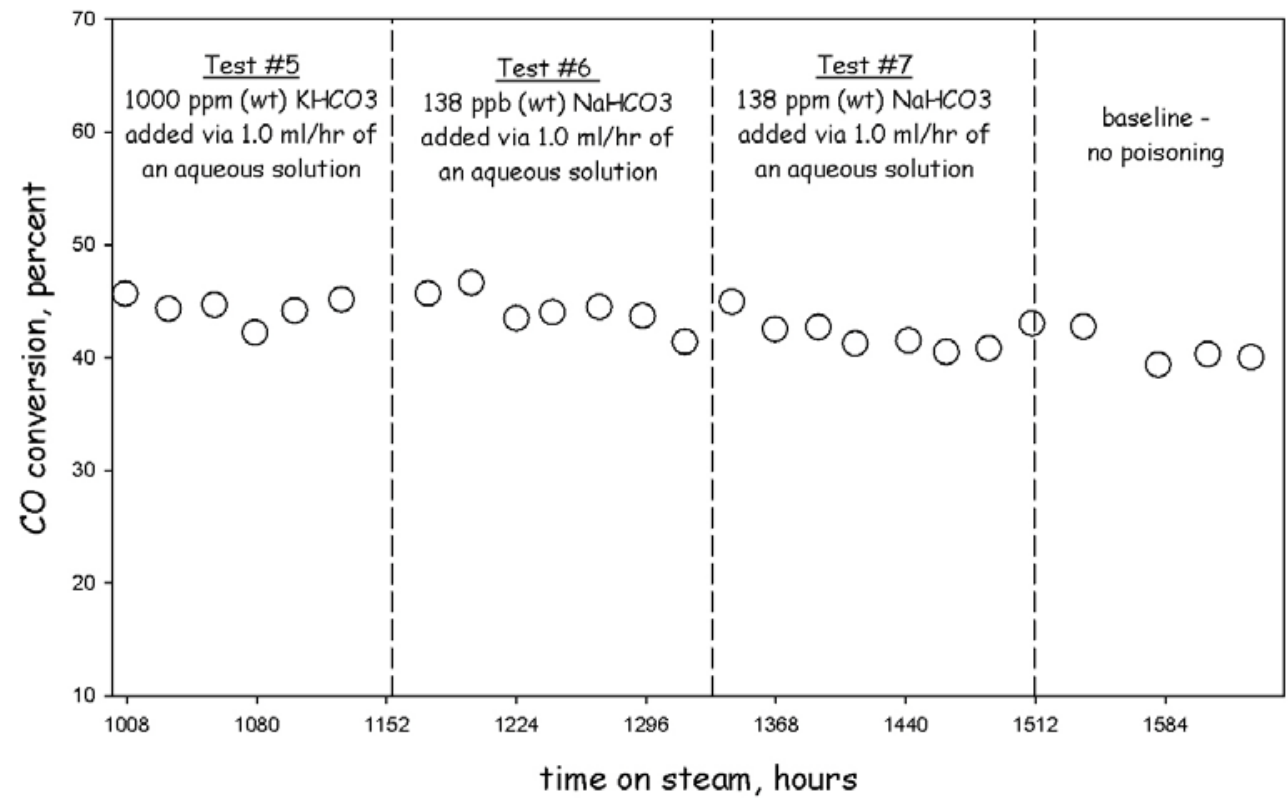

Figure 34

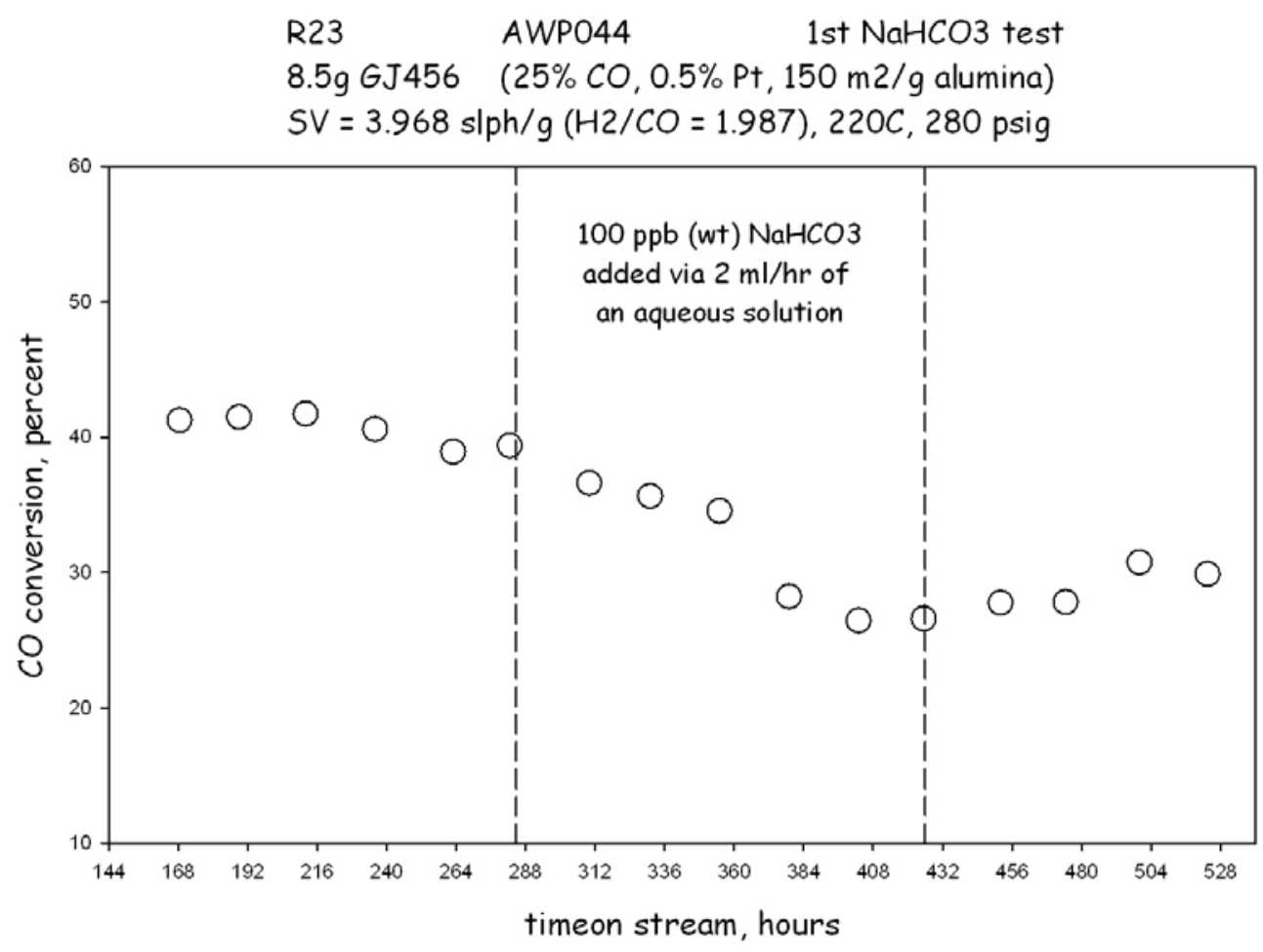

Figure 35 
R23 AWPO44 2nd \& 3rd NaHCO3 tests

$8.5 \mathrm{~g}$ GJ 456 (25\% Co, 0.5\% Pt, $150 \mathrm{~m}^{2} / \mathrm{g}$ alumina)

$S V=2.494 \mathrm{slph} / \mathrm{g}(\mathrm{H} 2 / \mathrm{CO}=2.017), 220 \mathrm{C}, 280 \mathrm{psig}$

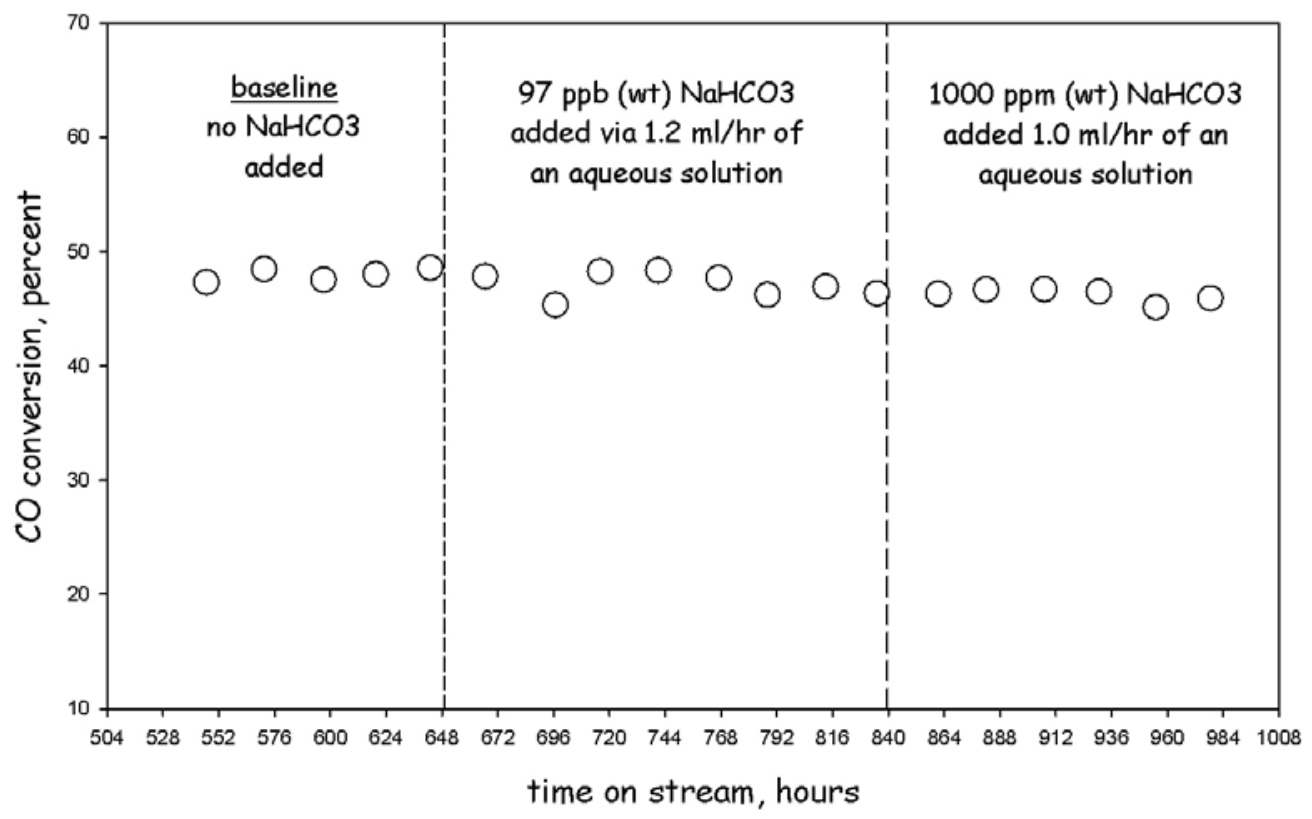

Figure 36

R21 AWP046 $10 \mathrm{ppm}(w t) \mathrm{HCl}$ test

$8.7 \mathrm{~g}$ GJ 456 (25\% Co, $0.5 \% \mathrm{Pt}, 150 \mathrm{~m}^{2} / \mathrm{g}$ alumina)

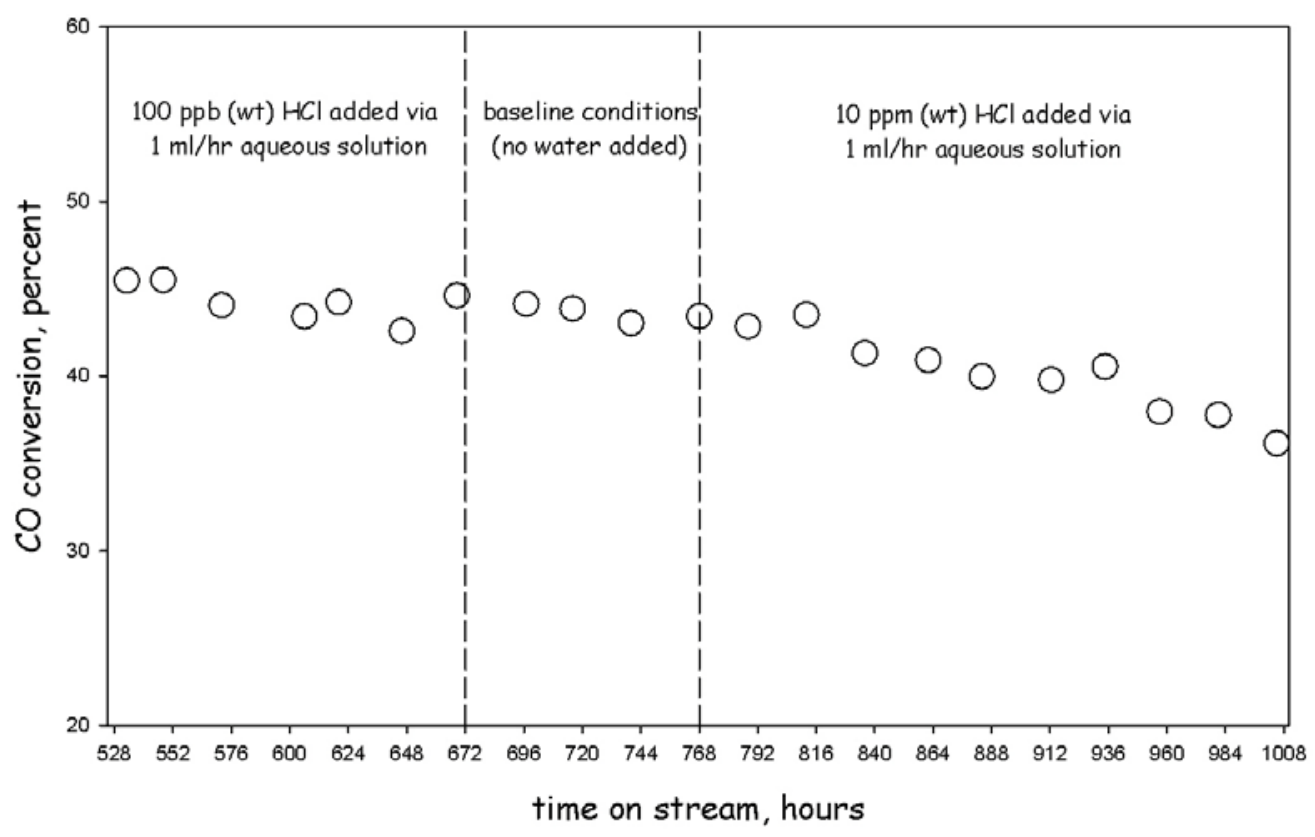

Figure 37 


\section{Conclusions}

Over the past year, the sensitivity of the Sud-Chemie, Inc. high temperature shift (HTS) Fe-Cr catalyst to various compounds of interest was evaluated using a fixed bed reactor. At the 100 ppbw level of either $\mathrm{KHCO}_{3}$ or $\mathrm{NaHCO}_{3}$, the catalyst displayed little deactivation during 21 days of TOS, at which the $\mathrm{CO}$ conversion dropped from 85 to $81 \%\left(\mathrm{KHCO}_{3}\right)$ and from 85 to 78\% $\left(\mathrm{NaHCO}_{3}\right)$, respectively. The impact of halide ions (e.g., $\mathrm{Cl}^{-}$by addition of $100 \mathrm{ppbw} \mathrm{HCl}$; $\mathrm{Br}^{-}$with 100 ppbw $\mathrm{HBr}$; and $\mathrm{F}^{-}$with 100 ppbw $\mathrm{HF}$ ) on catalyst stability was also investigated, and little deactivation was observed during 21 days of TOS, where CO conversion dropped from 85 to $82 \%$ in the case of $\mathrm{HCl}$ addition, and virtually no statistically significant deactivation was observed in the case of either $\mathrm{HBr}$ or $\mathrm{HF}$ co-feeding. During three weeks of sulfur poisoning by the addition of 1 ppmv $\mathrm{H}_{2} \mathrm{~S}$ under typical HTS conditions, the Fe-Cr based catalyst showed only a slightly lower CO conversion rate - approximately $2 \%$ less than that of a reference test carried out in the absence of sulfur poisoning. The catalyst was also found to be quite resistant to $\mathrm{NH}_{3}$ poisoning up to 5 ppm, while a slight decrease in activity was observed at higher levels (e.g., 12 ppm). Combinations of $\mathrm{NH}_{3}$ and $\mathrm{H}_{2} \mathrm{~S}$ were also examined, and a slight decrease in catalytic activity was only observed at the highest levels tested (e.g., 6 ppm $\mathrm{NH}_{3}, 0.6 \mathrm{ppm} \mathrm{H}_{2} \mathrm{~S}$ ).

Turning to the Fischer-Tropsch synthesis reaction, poisoning tests were conducted using continuously stirred tank reactors (CSTR). The $100 \mathrm{Fe} / 5.1 \mathrm{Si} / 3 \mathrm{~K} / 2 \mathrm{Cu}$ catalyst was found to be quite stable at 100 ppbw levels of $\mathrm{KCl}, \mathrm{NaCl}, \mathrm{KHCO}_{3}$, and $\mathrm{NaHCO}_{3}$, and at 400 ppbw levels of $\mathrm{NaCl}$ and $\mathrm{NaHCO}_{3}$. However, increasing the $\mathrm{KCl}$ or $\mathrm{KHCO}_{3}$ level to 400 ppbw led to a more rapid decline in $\mathrm{CO}$ conversion. Furthermore, increasing $\mathrm{NaHCO}_{3}$ to $40 \mathrm{ppm}$ also resulted in severe deactivation. When 100 ppbw or 400 ppbw of $\mathrm{HCl}$ was added, the iron catalyst was quite resistant, while in the case of $\mathrm{HBr}$ addition, the catalyst did decline in $\mathrm{CO}$ conversion during the 
first period of addition using 100 ppbw, but after a brief period without co-feeding of $\mathrm{HBr}, 400$ ppbw of $\mathrm{HBr}$ was added and the catalyst showed no further decline in $\mathrm{CO}$ conversion over more than 100 hours. At the highest levels of poisoning, $40 \mathrm{ppm}$, the catalyst displayed severe deactivation with both $\mathrm{HCl}$ and $\mathrm{HBr}$. With the addition of $\mathrm{NH}_{4} \mathrm{NO}_{3}$ to the feed, at levels up to 10 ppmw $\mathrm{NH}_{4} \mathrm{NO}_{3}$, it appears that the catalyst was quite resistant to poisoning; however, at higher levels 40 ppmw accelerated deactivation was noted. Additional tests will be required to verify repeatability, as power outages were problematic.

The sensitivity of a cobalt catalyst to Fischer-Tropsch synthesis under $\mathrm{KCl}$ and $\mathrm{NaCl}$ cofeeding was also assessed. Tests were carried out at 100, 190, and $600 \mathrm{ppb}$, followed by 2, 20, 100, 500 and $860 \mathrm{ppm}$. No discernible poisoning effects were observed for all but the highest concentrations. At the relatively high level of $500 \mathrm{ppm} \mathrm{KCl}$, the rate of decline was $\sim 0.7 \%$ per day, thus displaying evidence of some poisoning due to $\mathrm{KCl}$. At 860 ppmw $\mathrm{KCl}$ levels, $\mathrm{CO}$ conversion decreased rapidly and did not recover when the $\mathrm{KCl}$ feed was discontinued. With $\mathrm{NaCl}$, no discernible impact was observed at the $100 \mathrm{ppb}$ and $1 \mathrm{ppm}$ poisoning levels, but a run with a high concentration of $134 \mathrm{ppm}$ led to a decrease from $\mathrm{X}_{\mathrm{CO}}=40 \%$ to $30 \%$ in just two days. With $\mathrm{KHCO}_{3}$ co-feeding at the $1 \mathrm{ppm}, 10 \mathrm{ppm}, 100 \mathrm{ppm}$ and finally $1000 \mathrm{ppm}$ levels, no discernible loss in conversion was identified that could be attributed to $\mathrm{KHCO}_{3}$, and similar results were observed with $\mathrm{NaHCO}_{3}$. However, interruptions were encountered during $\mathrm{NaHCO}_{3}$ testing. Testing with $\mathrm{HCl}$ and $\mathrm{HBr}$ are ongoing. So far, with $\mathrm{HCl}$, no discernible loss in conversion was observed over the period of time tested at the 100 ppbw $\mathrm{HCl}$ level.

During the third year, data gathering will be completed and an assessment will be made, if possible, regarding the number of catalytic sites (e.g., with cobalt-based FT, \# of Co surface atoms) that are poisoned per mole of each contaminant. 


\section{References}

1. H.R. Linden, W.W. Bodle, B.S. Lee, K.C. Vyas, Annual Reviews Energy Vol. 1 (1976) pp. 65.

2. E. Iglesia, Appl. Catal. A: General 161 (1997) 59.

3. N. Sirimanothan, H.H. Hamdeh, Y. Zhang, B.H. Davis, Catal. Lett. 82 (2002) 181. 